Supporting Information for

\title{
Lysine-Targeting Reversible Covalent Inhibitors with Long Residence Time
}

\author{
Rahi M. Reja, Wenjian Wang, Yuhan Lyu, Fredrik Haeffner, and Jianmin Gao* \\ Email: jianmin.gao@bc.edu \\ Department of Chemistry, Boston College, 2609 Beacon Street, Chestnut Hill, MA 02467, \\ United States
}

\section{Contents}

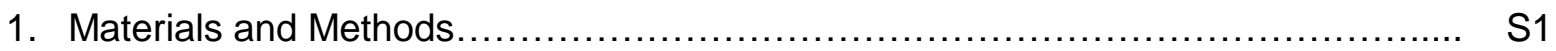

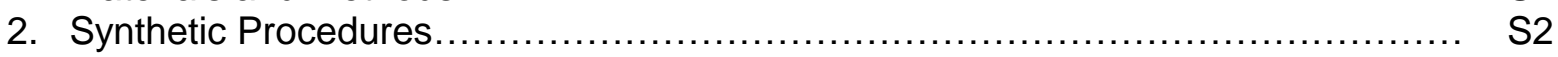

3. DFT Calculations for Mechanistic Study of the Conjugation Reaction................ S9

4. Procedure for Conjugation Reaction with Amines.................................. S11

5. X-Ray Crystal Structure of RMR1-2MEA Conjugate............................... S18

6. Procedure for $K_{\mathrm{d}}$ Determination between RMR1 and Amines....................... S20

7. Procedure for Determination of Kinetic Parameters $\quad$ S21

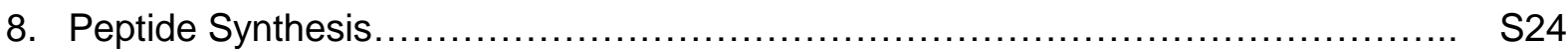

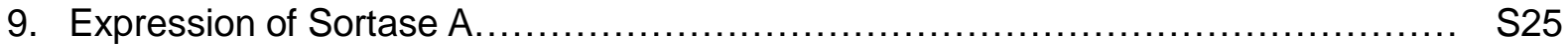

10. Biotinylation of Sortase $\quad$ S26

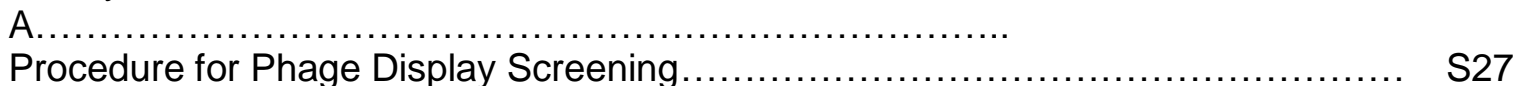

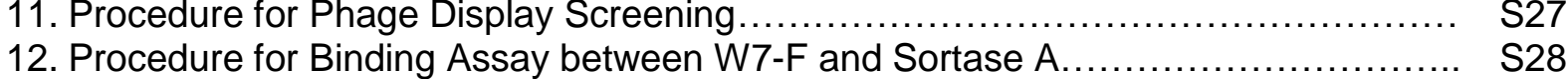

13. Molecular Docking Calculations for Binding of Peptide W7 with Sortase A.......... S29

14. Procedure for $\mathrm{IC}_{50}$ Value Determination of Peptides W7, W7-Linear and P1-P8_.... S S 30

15. Procedure for Determination of Kinetic Parameters between Peptide P3 and P5 with Sortase

S32

Procedure for Trypsin Digestion of Wildtype Sortase A and Sortase A-P5 Conjugates.........................................................................

17. Procedure for Inhibition of Sortase A Activity on S. aureus by Peptides W7, P3 and P5

18. LC-MS Trace and ESI-MS ${ }^{+}$of Purified Peptides........................................... S37

19. ${ }^{1} \mathrm{H}$ NMR and ${ }^{13} \mathrm{C}$ NMR Spectra.................................................... S49

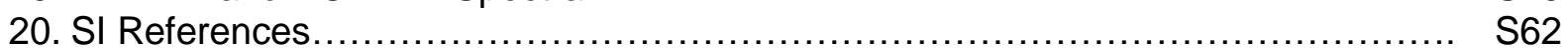




\section{Materials and Methods}

All chemicals, reagents and amino acids were purchased from the commercially available sources. Hexane, Methanol, Dichloromethane, Ethyl acetate, N,N-Dimethylformamide were purchased from the commercially available sources and used without further distillation. Silica gel (230-400 mesh) was used for column chromatography. The chemicals used for the biological experiments were purchased as biological grades from the commercial's sources. The Ph.D.-C7C Phage Display Peptide Library Kit and the E. coli K12 ER2738 strain were purchased from New England Biolabs. The S. aureus (ATCC 6358) was purchased from Microbiologic as a lyophilized pellet. Peptide synthesis was carried out on a Tribute Peptide Synthesizer from Protein Technologies. All final peptides were purified by reverse phase HPLC. ${ }^{1} \mathrm{H}(600 \mathrm{MHz})$ and ${ }^{13} \mathrm{C}(150$ $\mathrm{MHz}$ ) NMR spectra were recorded using the residual solvent signal as internal standards. All the NMR spectra in $1 \times$ PBS were carried out using water suppression. Chemical shifts $(\delta)$ and coupling constants $(\mathrm{J})$ are reported in parts per million $(\mathrm{ppm})$ and $\mathrm{Hz}$ respectively. ${ }^{11} \mathrm{~B} \mathrm{NMR}$ was recorded in $500 \mathrm{MHz}$ NMR instrument using $\mathrm{BF}_{3} . \mathrm{Et}_{2} \mathrm{O}$ as internal ${ }^{11} \mathrm{~B}$ reference. Mass-spec data for the small molecules as well as peptides were generated using an Agilent 6230 LC-TOF mass spectrometer. UV spectra were collected on a Nanodrop UV-Vis spectrometer. The fluorescence anisotropy experiments for the binding curve and the competition assay were carried out using Spectra Max M5 plate reader. Fluorescence images were taken using Zeiss Axiovert Fluorescence Microscope. Flow cytometry was carried out using BD Accuri C6 Plus instrument. The following methods were used to analyze the purity of the samples in the LC-MS instrument.

Solvent A contains $100 \%$ water ( $0.1 \%$ formic acid) and solvent B contains $100 \%$ acetonitrile $(0.1 \%$ formic acid).

Method A:

\begin{tabular}{|l|l|l|l|}
\hline Time (Min) & A [\%] & B[\%] & Flow [mL/Min] \\
\hline 0 & 95.0 & 5.0 & 0.2 \\
\hline 1 & 95.0 & 5.0 & 0.2 \\
\hline 7 & 5.0 & 95.0 & 0.2 \\
\hline 9 & 5.0 & 95.0 & 0.2 \\
\hline 12 & 95.0 & 5.0 & 0.2 \\
\hline 16 & 95.0 & 5.0 & 0.2 \\
\hline
\end{tabular}

Method B:

\begin{tabular}{|l|l|l|l|}
\hline Time (Min) & A [\%] & B[\%] & Flow [mL/Min] \\
\hline 0 & 95.0 & 5.0 & 0.2 \\
\hline 5 & 95.0 & 5.0 & 0.2 \\
\hline 24 & 5.0 & 95.0 & 0.2 \\
\hline 27 & 5.0 & 95.0 & 0.2 \\
\hline 28 & 95.0 & 5.0 & 0.2 \\
\hline 33 & 95.0 & 5.0 & 0.2 \\
\hline
\end{tabular}


Method C:

\begin{tabular}{|l|l|l|l|}
\hline Time (Min) & $\mathrm{A}[\%]$ & $\mathrm{B}[\%]$ & Flow [mL/Min] \\
\hline 0 & 95.0 & 5.0 & 0.2 \\
\hline 3 & 95.0 & 5.0 & 0.2 \\
\hline 10 & 5.0 & 95.0 & 0.2 \\
\hline 18 & 5.0 & 95.0 & 0.2 \\
\hline 20 & 95.0 & 5.0 & 0.2 \\
\hline 25 & 95.0 & 5.0 & 0.2 \\
\hline
\end{tabular}

\section{Synthetic Procedures}

\section{Scheme S1 (Compound 1):}<smiles>Nc1ccccc1C=O</smiles><smiles>CC1(C)OB(c2ccccc2CBr)OC1(C)C</smiles><smiles>CC1(C)OB(c2ccccc2CNc2ccccc2C=O)OC1(C)C</smiles>

1

2-Amino benzaldehyde (242 $\mathrm{mg}, 2 \mathrm{mmol}$ ) was dissolved in $5 \mathrm{~mL}$ of dry acetonitrile. To this, 2bromomethylphenylboronic acid pinacol ester (594 mg, $2 \mathrm{mmol}$ ) and anhydrous cesium carbonate (650 $\mathrm{mg}, 2 \mathrm{mmol}$ ) were added at room temperature. Then, the reaction mixture was refluxed at $85^{\circ} \mathrm{C}$ for about $12 \mathrm{~h}$. After completion of the reaction (confirmed by TLC), solvent was evaporated and directly subjected for column chromatography and purified using EtOAc/hexane as a solvent. Yield: $300 \mathrm{mg}(44.3 \%)$

${ }^{1} \mathrm{H}$ NMR $\left(600 \mathrm{MHz}, \mathrm{CDCl}_{3}\right) \delta 9.82(\mathrm{~s}, 1 \mathrm{H}), 7.86(\mathrm{~d}, J=6 \mathrm{~Hz}, 1 \mathrm{H}), 7.45(\mathrm{dd}, J=7.8,1.8 \mathrm{~Hz}, 1 \mathrm{H})$, $7.38-7.35(\mathrm{~m}, 2 \mathrm{H}), 7.33-7.31(\mathrm{~m}, 1 \mathrm{H}), 7.27-7.24(\mathrm{~m}, 2 \mathrm{H}), 6.76(\mathrm{~d}, J=8.4 \mathrm{~Hz}, 1 \mathrm{H}), 6.67(\mathrm{t}, J=$ $7.8 \mathrm{~Hz}, 1 \mathrm{H}), 4.73(\mathrm{~s}, 2 \mathrm{H}), 1.34(\mathrm{~s}, 12 \mathrm{H}) .{ }^{13} \mathrm{C}$ NMR (150 MHz, $\left.\mathrm{CDCl}_{3}\right) \delta$ 193.88, 150.77, 144.89, 136.75, 135.79, 131.36, 127.60, 126.69, 118.77, 115.11, 111.85, 84.00, 46.69, 25.00. MS-ESI+: $\mathrm{m} / \mathrm{z}$ calculated for $\mathrm{C}_{20} \mathrm{H}_{24} \mathrm{BNO}_{3}[\mathrm{M}+\mathrm{H}]^{+} 338.1927$, found 338.1770

Scheme S2 [Compound 2 (RMR1)]: 


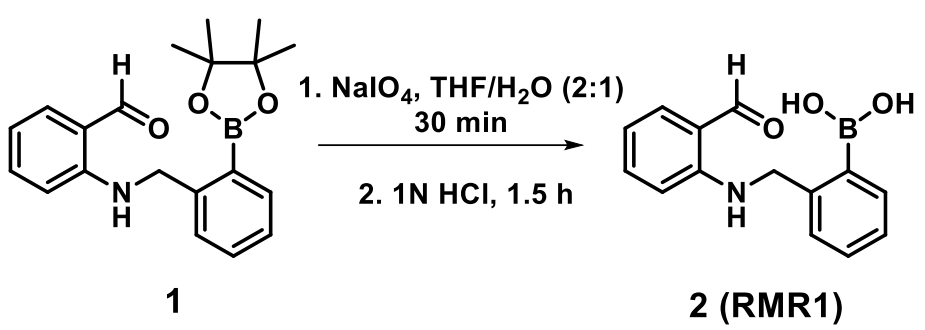

The pinacol ester of compound 1 was deprotected using reported protocol. ${ }^{1}$ Briefly, compound 1 (338 mg, $1 \mathrm{mmol}$ ) was dissolved in $1 \mathrm{~mL}$ of $\mathrm{THF} / \mathrm{H}_{2} \mathrm{O}(4: 1)$. To this solution, $\mathrm{NalO}_{4}(639 \mathrm{mg}, 3$ $\mathrm{mmol}$ ) was added to it and stirred for about $30 \mathrm{~min}$ at room temperature. After that, $1.5 \mathrm{~mL}$ of $1 \mathrm{~N}$ $\mathrm{HCl}$ solution was added and stirred for another $2 \mathrm{~h}$ at room temperature. After completion of the reaction (confirmed by TLC), THF was evaporated under vacuum and the aqueous solution was extracted with EtOAc $(3 \times 30 \mathrm{~mL})$. Then the combined organic layer was washed with brine $(3 \times$ $30 \mathrm{~mL}$ ) and dried over anhydrous $\mathrm{Na}_{2} \mathrm{SO}_{4}$. The crude compound was purified through column chromatography using EtOAc/hexane solvent system. Yield: 135 mg (53\%)

${ }^{1} \mathrm{H}$ NMR $\left(600 \mathrm{MHz}, \mathrm{DMSO}-d_{6} / \mathrm{D}_{2} \mathrm{O}\right) \delta 9.60(\mathrm{~s}, 1 \mathrm{H}), 8.54(\mathrm{t}, J=6 \mathrm{~Hz}, 1 \mathrm{H}), 7.47$ (dd, $J=7.8,1.2$ $\mathrm{Hz}, 1 \mathrm{H}), 7.40(\mathrm{dd}, J=7.2,1.8 \mathrm{~Hz}, 1 \mathrm{H}), 7.30-7.25(\mathrm{~m}, 3 \mathrm{H}), 7.18(\mathrm{td}, J=7.2,1.8 \mathrm{~Hz}, 1 \mathrm{H}), 6.67(\mathrm{~d}$, $J=8.4 \mathrm{~Hz}, 1 \mathrm{H}), 6.64-6.61(\mathrm{~m}, 1 \mathrm{H}) .{ }^{13} \mathrm{C}$ NMR $\left(150 \mathrm{MHz}, \mathrm{DMSO}-d_{6} / \mathrm{D}_{2} \mathrm{O}\right) \delta 197.10,144.09$, 138.73, 138.11, 135.09, 131.18, 129.42, 128.36, 122.42, 119.68, 117.21, 113.06, 113.03, 47.74. MS-ESI ${ }^{+}: m / z$ calculated for $\mathrm{C}_{14} \mathrm{H}_{14} \mathrm{BNO}_{3}[\mathrm{M}+\mathrm{H}]^{+} 256.1145$, found 256.1022

Scheme S3 [Compound 4 (RMR2)]:<smiles>O=Cc1ccccc1O</smiles><smiles>CC1(C)OB(c2ccccc2CBr)OC1(C)C</smiles>
$85^{\circ} \mathrm{C}, 16 \mathrm{~h}$

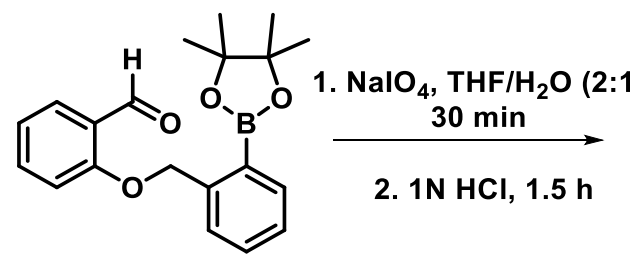

3<smiles>O=Cc1ccccc1OCc1ccccc1B(O)O</smiles>

4 (RMR2)

Compound 4 was synthesized by same protocol as mentioned for the compound 2(RMR1). Instead of 2-Amino benzaldehyde, salicylaldehyde was used.

Compound 3: ${ }^{1} \mathrm{H}$ NMR (600 MHz, $\left.\mathrm{CDCl}_{3}\right) \delta 10.54$ (s, 1H), 7.90 (dd, J=7.2, $1.8 \mathrm{~Hz}, 2 \mathrm{H}$ ), 7.85 (dd, $J=7.8,1.8 \mathrm{~Hz}, 2 \mathrm{H}), 7.55-7.52(\mathrm{~m}, 2 \mathrm{H}), 7.48(\mathrm{td}, J=7.48,1.2 \mathrm{~Hz}, 2 \mathrm{H}), 7.36(\mathrm{td}, J=7.2,1.2 \mathrm{~Hz}$, $1 \mathrm{H}), 7.10(\mathrm{~d}, J=12 \mathrm{~Hz}, 1 \mathrm{H}), 7.02(\mathrm{t}, J=12 \mathrm{~Hz}, 1 \mathrm{H}), 5.46(\mathrm{~s}, 2 \mathrm{H}), 1.27(\mathrm{~s}, 12 \mathrm{H}) .{ }^{13} \mathrm{C}$ NMR $(150$ $\left.\mathrm{MHz}_{\mathrm{CDCl}}\right) \delta 190.23,161.81,142.46,136.48,135.99,131.48,128.28,127.75,127.56,125.20$, 120.71, 113.35, 83.95, 70.38, 24.98. MS-ESI': $\mathrm{m} / \mathrm{z}$ calculated for $\mathrm{C}_{20} \mathrm{H}_{23} \mathrm{BO}_{4}[\mathrm{M}+\mathrm{H}]^{+} 339.1767$, found 339.1688

Compound 4 (RMR2): ${ }^{1} \mathrm{H}$ NMR $\left(600 \mathrm{MHz}, \mathrm{CD}_{3} \mathrm{OD}\right) \delta 10.46(\mathrm{~s}, 1 \mathrm{H}), 7.81$ (dd, $\left.J=7.8,1.8 \mathrm{~Hz}, 1 \mathrm{H}\right)$, 7.61-7.58 (m, 1H), $7.48(\mathrm{~d}, J=7.8 \mathrm{~Hz}, 1 \mathrm{H}), 7.45-7.40(\mathrm{~m}, 2 \mathrm{H}), 7.37(\mathrm{td}, J=7.5,1.2 \mathrm{~Hz}, 1 \mathrm{H})$, 
$7.23(\mathrm{~d}, J=8.4 \mathrm{~Hz}, 1 \mathrm{H}), 7.08(\mathrm{t}, J=7.2 \mathrm{~Hz}, 1 \mathrm{H}), 5.32(\mathrm{~s}, 2 \mathrm{H}) .{ }^{13} \mathrm{C}$ NMR $\left(150 \mathrm{MHz}, \mathrm{CD}_{3} \mathrm{OD}\right) \delta$ 191.24, 162.52, 141.08, 137.44, 133.21, 130.38, 129.99, 128.87, 128.70, 128.58, 126.26, 122.07, 114.58, 72.04. MS-ESI+: $m / z$ calculated for $\mathrm{C}_{14} \mathrm{H}_{13} \mathrm{BO}_{4}[\mathrm{M}+\mathrm{Na}]^{+} 279.0804$, found 279.0676

Scheme S4 [Compound 5(RMR3)]:

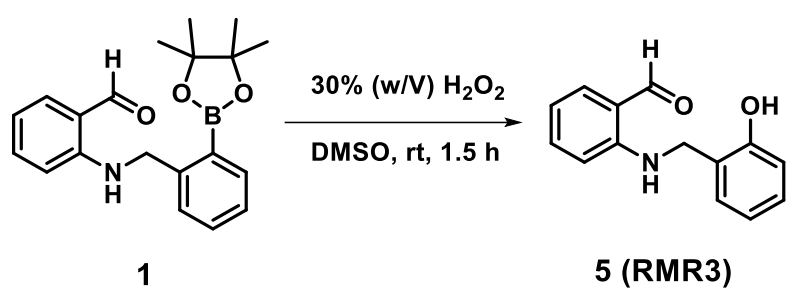

Compound 5 was synthesized from compound 1. Compound 1 (338 $\mathrm{mg}, 1 \mathrm{mmol}$ ) was dissolved in $5 \mathrm{~mL}$ of DMSO. To this solution, $1 \mathrm{~mL}$ of $30 \%(w t / V) \mathrm{H}_{2} \mathrm{O}_{2}$ was added. Then, the reaction mixture was stirred at room temperature for about $1.5 \mathrm{~h}$. After completion of the reaction (confirmed by TLC), $30 \mathrm{~mL}$ of water was added to it. Then, the reaction mixture was extracted with EtOAc $(3 \times 30 \mathrm{~mL})$. After that combined organic layer was washed with brine solution $(3 \times$ $30 \mathrm{~mL}$ ) and dried over anhydrous $\mathrm{Na}_{2} \mathrm{SO}_{4}$. Then the crude compound was purified through silica gel column chromatography using EtOAc/hexane as a solvent. Yield: $200 \mathrm{mg}(88.1 \%)$

${ }^{1} \mathrm{H}$ NMR $\left(600 \mathrm{MHz}, \mathrm{CDCl}_{3}\right) \delta 9.86(\mathrm{~s}, 1 \mathrm{H}), 7.53(\mathrm{dd}, J=7.8,1.8 \mathrm{~Hz}, 1 \mathrm{H}), 7.40-7.38(\mathrm{~m}, 1 \mathrm{H}), 7.23-$ $7.22(\mathrm{~m}, 1 \mathrm{H}), 7.18(\mathrm{td}, J=7.8,1.8 \mathrm{~Hz}, 1 \mathrm{H}), 6.90(\mathrm{td}, J=7.2,1.2 \mathrm{~Hz}, 1 \mathrm{H}), 6.84-6.79(\mathrm{~m}, 3 \mathrm{H})$, 4.51 (s, 2H). ${ }^{13} \mathrm{C}$ NMR (125 MHz, CDCl 3 ) $\delta 194.39,154.61,150.75,136.82,136.05,128.96$, 128.95, 123.91, 120.98, 119.66, 116.45, 116.09, 112.23, 43.68.MS-ESI+: $\mathrm{m} / \mathrm{z}$ calculated for $\mathrm{C}_{14} \mathrm{H}_{13} \mathrm{NO}_{2}[\mathrm{M}+\mathrm{H}]^{+} 228.1025$, found 228.0893

Scheme S5 (Compound 6):<smiles>CC(=O)c1ccc(O)cc1O</smiles>
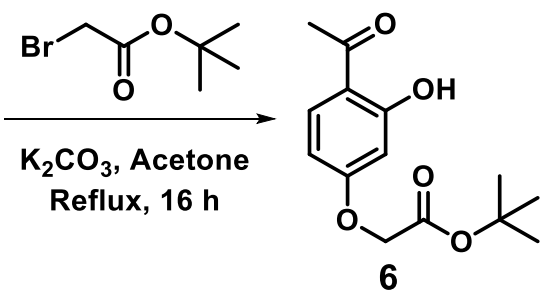

Compound 6 was synthesized using reported protocol. ${ }^{2}$ Briefly, 2,4-Dihydroxyacetophenone (1.5 $\mathrm{g}, 10 \mathrm{mmol}$ ) was dissolved in $50 \mathrm{~mL}$ of acetone. To this solution, anhydrous $\mathrm{K}_{2} \mathrm{CO}_{3}(1.38 \mathrm{~g}, 10$ $\mathrm{mmol})$ and tert-butyl bromoacetate $(1.2 \mathrm{~mL}, 10 \mathrm{mmol})$ was added. Then, the reaction mixture was refluxed at $85{ }^{\circ} \mathrm{C}$ for overnight. After completion of the reaction (confirmed by TLC), solvent was evaporated under vacuum and extracted with EtOAc $(3 \times 30 \mathrm{~mL})$. After that the combined organic layer was washed with brine solution $(3 \times 30 \mathrm{~mL})$ and dried over anhydrous $\mathrm{Na}_{2} \mathrm{SO}_{4}$. The crude 
product was purified through silica gel column chromatography using EtOAc/hexane as solvent system. Yield: $2 \mathrm{~g}(77 \%)$

${ }^{1} \mathrm{H}$ NMR $\left(600 \mathrm{MHz}, \mathrm{CDCl}_{3}\right) \delta 12.67(\mathrm{~s}, 1 \mathrm{H}), 7.64(\mathrm{~d}, J=8 \mathrm{~Hz}, 1 \mathrm{H}), 6.47$ (dd, $\left.J=8.7,2.4 \mathrm{~Hz}, 1 \mathrm{H}\right)$, $6.34(\mathrm{~d}, J=2.4 \mathrm{~Hz}, 1 \mathrm{H}), 4.53(\mathrm{~s}, 2 \mathrm{H}), 2.54(\mathrm{~s}, 3 \mathrm{H}), 1.48(\mathrm{~s}, 9 \mathrm{H}) .{ }^{13} \mathrm{C} \mathrm{NMR}\left(150 \mathrm{MHz}, \mathrm{CDCl}_{3}\right) \delta$ 202.82, 167.13, 165.14, 164.30, 132.57, 114.62, 107.83, 101.77, 83.00, 65.52, 28.14, 26.38. MSESI ${ }^{+}: \mathrm{m} / z$ calculated for $\mathrm{C}_{14} \mathrm{H}_{18} \mathrm{O}_{5}[\mathrm{M}+\mathrm{Na}]^{+} 267.1232$, found 267.1183

Scheme S6 (Compound 7):
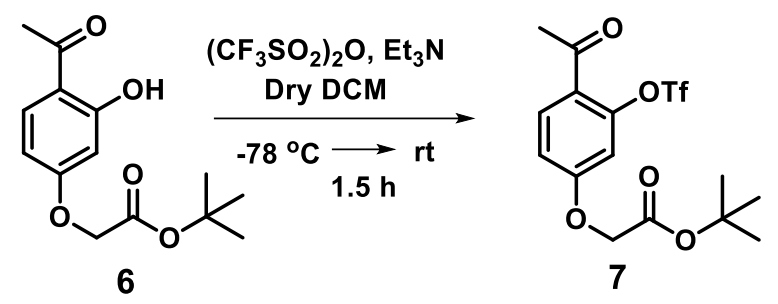

Compound 6 ( $2 \mathrm{~g}, 7.5 \mathrm{mmol})$ was dissolved in dry DCM. To this solution, triethylamine $(1.4 \mathrm{~mL}$, $10 \mathrm{mmol}$ ) was added at room temperature and stirred for $5 \mathrm{~min}$. After that, triflic anhydride (1.7 $\mathrm{mL}, 10 \mathrm{mmol}$ ) was dropwise added to it at $-78{ }^{\circ} \mathrm{C}$. Then, the reaction mixture was stirred for another $1 \mathrm{~h}$ at room temperature. After completion of the reaction (confirmed by TLC), reaction was quenched with saturated $\mathrm{NaHCO}_{3}$ solution and extracted with $\mathrm{DCM}(3 \times 50 \mathrm{~mL})$. The combined organic layer was washed with brine solution and dried over anhydrous MgSO4. The crude product was purified through silica gel column chromatography using EtOAc/hexane as solvent system. Yield: $2 \mathrm{~g}(67.1 \%)$

${ }^{1} \mathrm{H}$ NMR $\left(600 \mathrm{MHz}, \mathrm{CDCl}_{3}\right) \delta 7.84(\mathrm{~d}, J=12 \mathrm{~Hz}, 1 \mathrm{H}), 6.94(\mathrm{dd}, J=2.4,9 \mathrm{~Hz}, 1 \mathrm{H}), 6.83(\mathrm{~d}, J=2.4$ $\mathrm{Hz}, 1 \mathrm{H}), 4.58(\mathrm{~s}, 2 \mathrm{H}), 2.59(\mathrm{~s}, 3 \mathrm{H}), 1.49(\mathrm{~s}, 9 \mathrm{H}) .{ }^{13} \mathrm{C} \mathrm{NMR}\left(150 \mathrm{MHz}, \mathrm{CDCl}_{3}\right) \delta^{13} \mathrm{C} \mathrm{NMR}(151 \mathrm{MHz}$, $\left.\mathrm{Cdcl}_{3}\right) \delta 195.11,166.65,161.92,148.50,132.78,125.02,121.93,119.80,117.67,115.55,114.01$, 109.69, 83.49, 65.97, 29.32, 28.11. MS-ESI+: $\mathrm{m} / \mathrm{z}$ calculated for $\mathrm{C}_{15} \mathrm{H}_{17} \mathrm{~F}_{3} \mathrm{O}_{7} \mathrm{~S}[\mathrm{M}+\mathrm{Na}]^{+}$421.0544, found 421.0294

Scheme S7 (Compound 8):

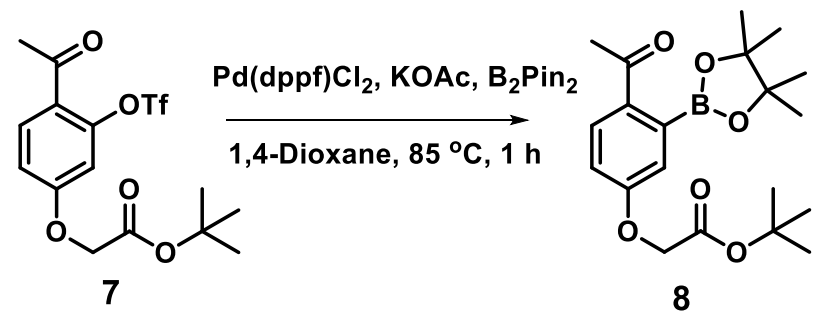

The compound 7 ( $800 \mathrm{mg}, 2 \mathrm{mmol}$ ) was dissolved in $10 \mathrm{~mL}$ of dry dioxane. To this solution, potassium acetate (392 $\mathrm{mg}, 4 \mathrm{mmol}$ ), bis pinacolate diborane (1g, $4 \mathrm{mmol})$ and $\mathrm{Pd}(\mathrm{dppf}) \mathrm{Cl}_{2} . \mathrm{DCM}$ (81 mg, 10\%) were added to it. Then, the solution was degassed for 30 mins. After that, it was heated at $85^{\circ} \mathrm{C}$ for about $1 \mathrm{~h}$. After completion of the reaction (confirmed by TLC), $30 \mathrm{~mL}$ of brine was added to it. Then the reaction mixture was extracted with EtOAc $(3 \times 30 \mathrm{~mL})$. After that the 
combined organic layer was washed with brine solution $(3 \times 30 \mathrm{~mL})$ and dried over anhydrous $\mathrm{Na}_{2} \mathrm{SO}_{4}$. The crude product was purified through silica gel column chromatography using EtOAc/hexane solvent system. Yield: $400 \mathrm{mg}(53.1 \%)$

${ }^{1} \mathrm{H}$ NMR $\left(600 \mathrm{MHz}, \mathrm{CDCl}_{3}\right) \delta 7.78(\mathrm{~d}, J=12 \mathrm{~Hz}, 1 \mathrm{H}), 6.94(\mathrm{~d}, J=6 \mathrm{~Hz}, 1 \mathrm{H}), 6.89$ (dd, $J=12,6$ $\mathrm{Hz}, 1 \mathrm{H}), 4.57(\mathrm{~s}, 2 \mathrm{H}), 2.55(\mathrm{~s}, 3 \mathrm{H}), 1.48(\mathrm{~s}, 9 \mathrm{H}), 1.43(\mathrm{~s}, 12 \mathrm{H}) \cdot{ }^{13} \mathrm{C} \mathrm{NMR}\left(150 \mathrm{MHz}, \mathrm{CDCl}_{3}\right) \delta$ 198.54, 167.46, 161.56, 134.40, 130.76, 117.92, 114.76, 83.80, 82.88, 65.84, 28.15, 25.05.MSESI $^{+}: \mathrm{m} / z$ calculated for $\mathrm{C}_{20} \mathrm{H}_{29} \mathrm{BO}_{6}[\mathrm{M}+\mathrm{H}]^{+} 377.2135$, found 377.1871

Scheme S8 [Compound 9 (APBA-Acid)]:

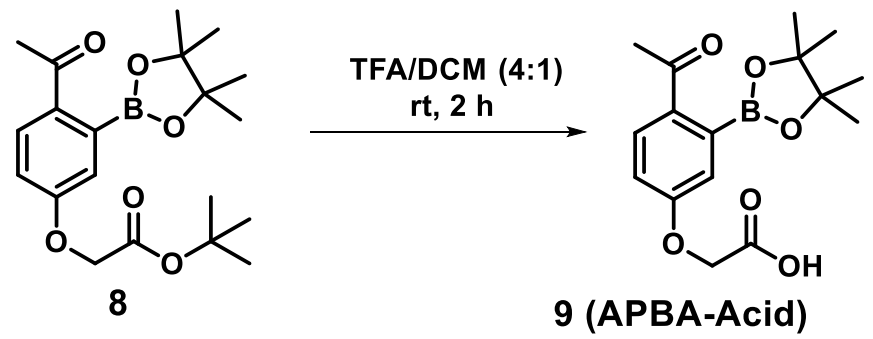

Compound 8 (376 mg, $1 \mathrm{mmol}$ ) was dissolved in $10 \mathrm{~mL}$ of TFA/DCM (4:1). Then, the reaction mixture was stirred for about $2 \mathrm{~h}$ at room temperature. After completion of the reaction (confirmed by LC-MS), TFA was evaporated under vacuum. Then, compound was precipitated using cold diethyl ether. The precipitation was centrifuged and dried in vacuum. The compound was directly used for coupling in solid phase peptide synthesis without any further purification. Yield: $250 \mathrm{mg}$ $(78.1 \%)$

${ }^{1} \mathrm{H}$ NMR $\left(600 \mathrm{MHz}, \mathrm{DMSO}-d_{6}\right) \delta 13.09(\mathrm{~s}, 1 \mathrm{H}), 7.96(\mathrm{~d}, J=12 \mathrm{~Hz}, 1 \mathrm{H}), 7.00(\mathrm{dd}, J=3,6 \mathrm{~Hz}, 1 \mathrm{H})$, $6.87(\mathrm{~d}, J=6 \mathrm{~Hz}, 1 \mathrm{H}), 4.80(\mathrm{~s}, 2 \mathrm{H}), 2.52(\mathrm{~s}, 3 \mathrm{H}), 1.31(\mathrm{~s}, 12 \mathrm{H}) \cdot{ }^{13} \mathrm{C} \mathrm{NMR}\left(150 \mathrm{MHz}\right.$, DMSO- $\left.d_{6}\right) \delta$ 198.00, 169.76, 161.10, 133.50, 131.39, 117.79, 113.82, 82.92, 64.52, 25.01, 24.65.MS-ESI+: $\mathrm{m} / \mathrm{z}$ calculated for $\mathrm{C}_{16} \mathrm{H}_{21} \mathrm{BO}_{6}[\mathrm{M}+\mathrm{H}]^{+} 321.1590$, found 321.1702

Scheme S9 (Compound 10):<smiles>COC(=O)c1ccc(B2OC(C)(C)C(C)(C)O2)c(CNc2ccccc2C(=O)O)c1</smiles> 
2-Amino benzaldehyde (605 $\mathrm{mg}, 5 \mathrm{mmol}$ ) was dissolved in $5 \mathrm{~mL}$ of dry DMF. To this solution, sodium hydride $(240 \mathrm{mg}, 10 \mathrm{mmol}$ ) was added under inert atmosphere. Then the reaction mixture was stirred for about $30 \mathrm{~min}$ at room temperature. After $30 \mathrm{~min}$, methyl 3-(bromomethyl)-4(4,4,5,5-tetramethyl-1,3,2-dioxaborolan-2-yl)benzoate $(1.7 \mathrm{~g}, 5 \mathrm{mmol})$ was added to it . Then, the reaction mixture was stirred for about $16 \mathrm{~h}$ at room temperature under inert atmosphere. After completion of the reaction (confirmed by TLC), $30 \mathrm{~mL}$ of brine solution was added to it. Then, the reaction mixture was extracted with $\mathrm{EtOAc}(3 \times 30 \mathrm{~mL})$. After that the combined organic layer was washed with brine solution $(3 \times 30 \mathrm{~mL})$ and dried over anhydrous $\mathrm{Na}_{2} \mathrm{SO}_{4}$. Then the crude compound was purified through silica gel column chromatography using EtOAc/hexane as solvent. Yield: $400 \mathrm{mg}(20 \%)$

${ }^{1} \mathrm{H}$ NMR $\left(600 \mathrm{MHz}, \mathrm{CDCl}_{3}\right) \delta 9.82(\mathrm{~s}, J=1 \mathrm{~Hz}, 1 \mathrm{H}), 8.01$ (bs, $\left.1 \mathrm{H}\right), 7.92(\mathrm{dd}, J=3,0.6 \mathrm{~Hz}, 2 \mathrm{H})$, $7.46(\mathrm{dd}, J=7.8,1.8 \mathrm{~Hz}, 1 \mathrm{H}), 7.35-7.32(\mathrm{~m}, 1 \mathrm{H}), 6.75(\mathrm{~d}, J=8.4 \mathrm{~Hz}, 1 \mathrm{H}), 6.68(\mathrm{t}, J=7.8 \mathrm{~Hz}, 1 \mathrm{H})$, $4.73(\mathrm{~s}, 2 \mathrm{H}), 3.89(\mathrm{~s}, 3 \mathrm{H}), 1.34(\mathrm{~s}, 12 \mathrm{H}) .{ }^{13} \mathrm{C}$ NMR $\left(150 \mathrm{MHz}, \mathrm{CDCl}_{3}\right) \delta 193.91,167.10,150.62$, 145.34, 136.81, 136.78, 135.86, 132.41, 128.68, 127.66, 118.86, 115.32, 111.62, 84.43, 52.33, 46.69, 24.98. MS-ESI+: $m / z$ calculated for $\mathrm{C}_{22} \mathrm{H}_{26} \mathrm{BNO}_{5}[\mathrm{M}+\mathrm{H}]^{+} 396.1982$, found 396.1782

\section{Scheme S10 [Compound 11 (RMR1-Acid)]:}

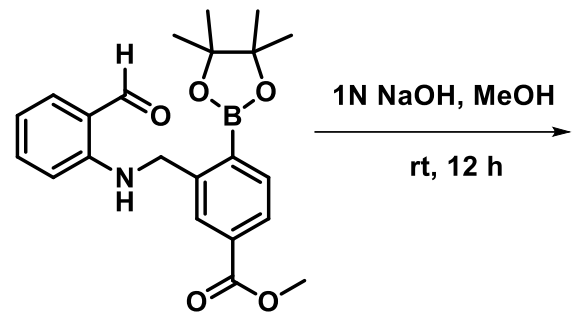

10<smiles>CC1(C)OB(c2ccc(C(=O)O)cc2CNc2ccccc2C=O)OC1(C)C</smiles>

11 (RMR1-Acid)

Compound 10 ( $400 \mathrm{mg}, 1 \mathrm{mmol}$ ) was dissolved in $35 \mathrm{~mL}$ methanol. To this solution, $5 \mathrm{~mL}$ of $1(\mathrm{~N})$ $\mathrm{NaOH}$ solution was added drop wise. Then, the reaction mixture was stirred for about $12 \mathrm{~h}$. After completion of the reaction (confirmed by TLC), methanol was evaporated and the aqueous layer was acidified with $5 \% \mathrm{HCl}$ solution. Then, aqueous layer was mixture was extracted with EtOAc $(3 \times 30 \mathrm{~mL})$. After that the combined organic layer was washed with brine solution $(3 \times 30 \mathrm{~mL})$ and dried over anhydrous $\mathrm{Na}_{2} \mathrm{SO}_{4}$. Then the crude compound was purified through silica gel column chromatography using EtOAc/hexane as solvent. Yield: $150 \mathrm{mg}(40 \%)$

${ }^{1} \mathrm{H}$ NMR $\left(600 \mathrm{MHz}, \mathrm{CD}_{3} \mathrm{OD}\right) \delta 9.80$ (s, 1H), 8.06 (bs, $\left.1 \mathrm{H}\right), 7.94-7.90(\mathrm{~m}, 2 \mathrm{H}), 7.54$ (dd, $J=7.8$, $1.8 \mathrm{~Hz}, 1 \mathrm{H}), 7.41-7.38(\mathrm{~m}, 1 \mathrm{H}), 6.85(\mathrm{~d}, J=4.5 \mathrm{~Hz}, 1 \mathrm{H}), 6.71(\mathrm{t}, J=7.2 \mathrm{~Hz}, 1 \mathrm{H}), 4.73(\mathrm{~s}, 2 \mathrm{H}), 1.35$ (s, 12H). ${ }^{13} \mathrm{C}$ NMR $\left(150 \mathrm{MHz}, \mathrm{CD}_{3} \mathrm{OD}\right) \delta 195.50,169.58,151.74,146.76,137.92,137.55,137.00$, 130.11, 128.71, 120.04, 116.33, 112.42, 85.57, 47.21, 25.16. MS-ESI+: $\mathrm{m} / \mathrm{z}$ calculated for $\mathrm{C}_{21} \mathrm{H}_{24} \mathrm{BNO}_{5}[\mathrm{M}+\mathrm{H}]^{+} 382.1825$, found 382.1631

Scheme S11 (Compound 12): 


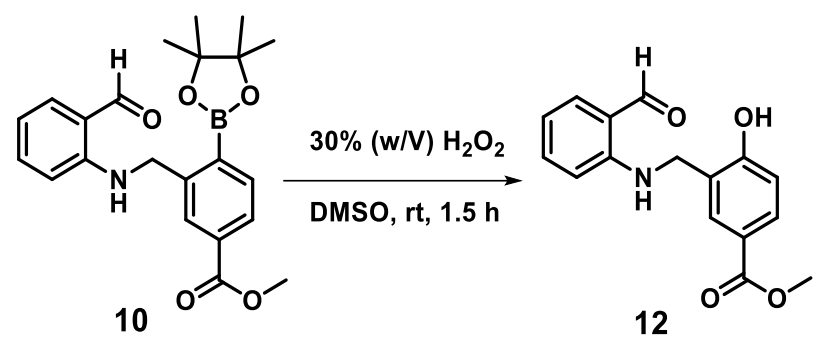

Compound 12 was synthesized from compound 10. Compound 10 (396 mg, 1mmol) was dissolved in $5 \mathrm{~mL}$ of DMSO. To it, $1 \mathrm{~mL}$ of $30 \%(w t / V) \mathrm{H}_{2} \mathrm{O}_{2}$ was added. The reaction mixture was stirred at room temperature for about 1.5h. After completion of the reaction (confirmed by TLC), $30 \mathrm{~mL}$ of water was added to it. Then, the reaction mixture was extracted with EtOAc $(3 \times 30 \mathrm{~mL})$. After that, the combined organic layer was washed with brine solution $(3 \times 30 \mathrm{~mL})$ and dried over anhydrous $\mathrm{Na}_{2} \mathrm{SO}_{4}$. Then the crude compound was purified through silicagel column chromatography using EtOAc/hexane as solvent. Yield: $200 \mathrm{mg}$ (70.1\%)

${ }^{1} \mathrm{H}$ NMR $\left(600 \mathrm{MHz}, \mathrm{CDCl}_{3}\right) \delta 9.87(\mathrm{~s}, 1 \mathrm{H}), 7.95(\mathrm{~d}, J=1.8 \mathrm{~Hz}, 1 \mathrm{H}), 7.89(\mathrm{dd}, J=8.4,2.4 \mathrm{~Hz}, 1 \mathrm{H})$, $7.55(\mathrm{dd}, J=6.6,1.2 \mathrm{~Hz}, 1 \mathrm{H}), 7.42-7.39(\mathrm{~m}, 1 \mathrm{H}), 6.87-6.85(\mathrm{~m}, 2 \mathrm{H}), 6.82(\mathrm{~d}, J=8.6 \mathrm{~Hz}, 1 \mathrm{H}), 4.53$ (s, 2H), 3.87 (s, 3H). ${ }^{13} \mathrm{C}$ NMR $\left(150 \mathrm{MHz}, \mathrm{CDCl}_{3}\right) \delta 194.57,167.03,159.40,150.54,136.92$, 136.23, 131.15, 131.00, 123.81, 122.65, 119.88, 116.99, 116.09, 112.37, 52.11, 44.12.

MS-ESI+: $m / z$ calculated for $\mathrm{C}_{16} \mathrm{H}_{15} \mathrm{NO}_{4}[\mathrm{M}+\mathrm{H}]^{+} 286.1079$, found 286.0894

Scheme S12 [Compound 13 (RMR3-Acid)]:

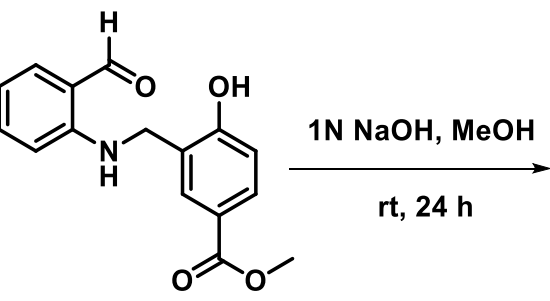

12<smiles>O=Cc1ccccc1NCc1cc(C(=O)O)ccc1O</smiles>

13 (RMR3-Acid)

Compund 12 (200 mg, $0.7 \mathrm{mmol}$ ) was dissolved in $20 \mathrm{~mL}$ methanol. To this solution, $5 \mathrm{~mL}$ of $1(\mathrm{~N})$ $\mathrm{NaOH}$ solution was added dropwise. Then the reaction mixture was stirred for about $24 \mathrm{hr}$. After completion of the reaction (confirmed by TLC), methanol was evaporated and the aqueous layer was acidified with $5 \% \mathrm{HCl}$ solution. Then the aqueous layer was was extracted with EtOAc $(3 \times$ $30 \mathrm{~mL})$. After that, the combined organic layer was washed with brine solution $(3 \times 30 \mathrm{~mL})$ and dried over anhydrous $\mathrm{Na}_{2} \mathrm{SO}_{4}$. Then the crude compound was purified through silica gel column chromatography using EtOAc/hexane as solvent. Yield: $100 \mathrm{mg}$ (52.7\%)

${ }^{1} \mathrm{H}$ NMR $\left(600 \mathrm{MHz}\right.$, DMSO- $\left.d_{6}\right) \delta 12.40$ (bs, $\left.1 \mathrm{H}\right), 10.60$ (bs, $\left.1 \mathrm{H}\right), 9.83(\mathrm{~s}, 1 \mathrm{H}), 8.65(\mathrm{t}, J=6 \mathrm{~Hz}$, $1 \mathrm{H}), 7.78(\mathrm{~d}, J=1.8 \mathrm{~Hz}, 1 \mathrm{H}), 7.71(\mathrm{dd}, J=8.4,2.4 \mathrm{~Hz}, 1 \mathrm{H}), 7.61(\mathrm{dd}, J=7.8,1.8 \mathrm{~Hz}, 1 \mathrm{H}), 7.40-$ $7.37(\mathrm{~m}, 1 \mathrm{H}), 6.91(\mathrm{~d}, J=8.4 \mathrm{~Hz}, 1 \mathrm{H}), 6.74(\mathrm{~d}, J=9 \mathrm{~Hz}, 1 \mathrm{H}), 6.69(\mathrm{t}, J=7.8,1 \mathrm{H}), 4.44(\mathrm{~d}, J=6$ $\mathrm{Hz}, 2 \mathrm{H}) .{ }^{13} \mathrm{C}$ NMR $\left(150 \mathrm{MHz}, \mathrm{DMSO}-d_{6}\right) \delta 194.34,167.15,159.45,149.90,136.82,135.91$, 130.20, 129.97, 124.70, 121.33, 118.29, 114.92, 114.84, 111.11, 40.64. MS-ESI ${ }^{+}: \mathrm{m} / \mathrm{z}$ calculated for $\mathrm{C}_{15} \mathrm{H}_{13} \mathrm{NO}_{4}[\mathrm{M}+\mathrm{H}]^{+}$272.0922, found 272.1006 


\section{DFT Calculation for Mechanistic Study of the Conjugation Reaction}

A mechanism of how the diazaborine compound RMR1 warhead is formed from RMR1 was determined using density functional theory (DFT) using the M06-2X functional and the $6-31+G^{*}$ basis set. Water solvation was modeled by the polarizable continuum model PCM as well as by one explicit water molecule that helps facilitating proton transfer reactions. All stationary points were characterized by means of frequency calculations. The calculations were carried out using the Gaussian 16 computer program ${ }^{3}$. The relative standard enthalpies $(298 \mathrm{~K}, 1 \mathrm{~atm})$ are given in $\mathrm{kcal} / \mathrm{mol}$. The number of reactants of the reaction is two and the number of products is three. Consequently, the translational entropy part of the reaction entropy is positive to some extent. The reaction was modeled such that all geometries on the potential energy surface represent structure complexes held together via hydrogen bonding (a reasonable assumption given that the reaction takes place in water). The ground state of the reaction (see Figure S1 below) is modeled by a hydrogen bonded complex (GS). The aryl amine transfers a proton via the explicit water molecule (TS1) to one of the hydroxide anions bound to boron causing a ligand exchange; water leaves boron and the deprotonated aryl amine instead bonds to it forming intermediate I1. The enthalpy of activation is $18.7 \mathrm{kcal} / \mathrm{mol}$ and 11 is $15.4 \mathrm{kcal} / \mathrm{mol}$ higher in energy than GS. Next, the methylamine attacks the carbonyl of the RMR1 compound via TS2 $(17.1 \mathrm{kcal} / \mathrm{mol})$ forming the zwitterion ion intermediate 12 only $0.5 \mathrm{kcal} / \mathrm{mol}$ higher in energy than GS. Next, the two protons of the amino group of methylamine (now bonded to the carbonyl) are transferred, one at a time. One of them is transferred to the oxyanion (formed after addition of the methylamine to the carbonyl) via two water molecules (TS3) with a barrier of $12.7 \mathrm{kcal} / \mathrm{mol}$ generating intermediate I3 $(13.3 \mathrm{kcal} / \mathrm{mol})$. I 3 is a minimum on the potential energy surface, see Figure S1) Then, via ligand exchange, I3 --> TS4 --> 14 --> single-bond rotation (see Figure S1) --> I5 --> TS5 intermediate 16 forms $(7.7 \mathrm{kcal} / \mathrm{mol})$. Thereafter the second proton is transferred to the aryl amine nitrogen via TS6 forming 17. Finally, the proton is transferred to the alcohol oxygen via the ratedetermining step (TS7) with a barrier of $26.1 \mathrm{kcal} / \mathrm{mol}$, forming a second water and the diazaborine product. The overall reaction is endothermic by $1.3 \mathrm{kcal} / \mathrm{mol}$. The standard reaction entropy $\square$ SOrxn is challenging to compute, however, given the fact that the number of product molecules (3) is greater than the number of reactant molecules (2) it seems reasonable that the exergonicity

of the reaction originates from this fact. The conversion of the reaction is also rather low $(50 \%$ for Lysine), which shows that the exergonicity of the reaction is modest (the reaction is reversible) rationalizing the computed heat of reaction being close to zero. 
Proposed Mechanism of Diazaborine RMR1 Warhead Formation

Deprotonation of aromatic amine. Ligand exchange at boron center. First water is formed.
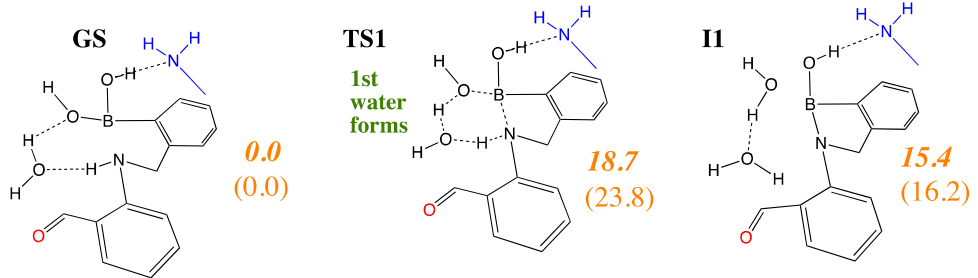

Nucleophilic attack by methylamine on carbonyl. Zwitterionic borate complex forms

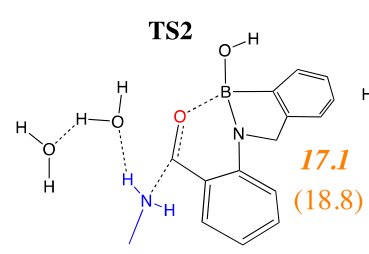

methylamine makes

nucleophiic attack on carbonyl zwitterion forms
Transfer of first methylamine proton to carbonyl oxygen

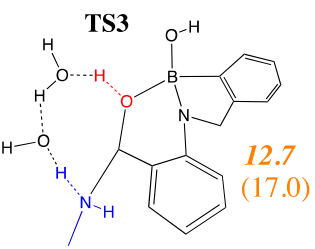

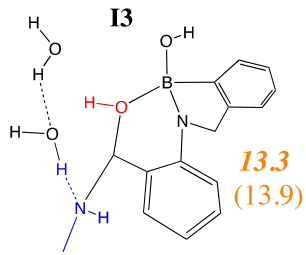

1st methylamine proton transfers to carbonyl oxygen

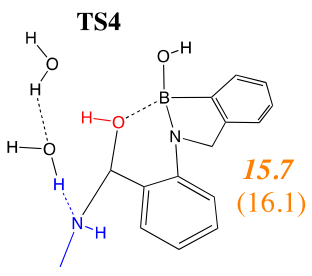

Ligand exchange of alcohol oxygen and amine nitrogen at boron center
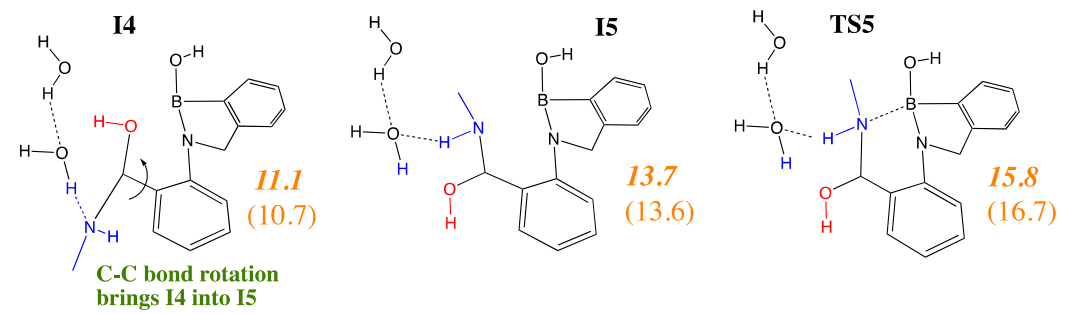

Transfer of second methylamine proton to aryl amine nitrogen.

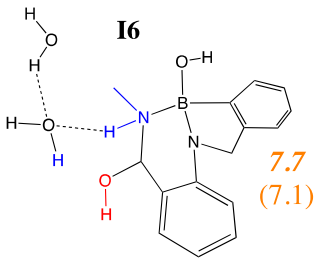

TS6
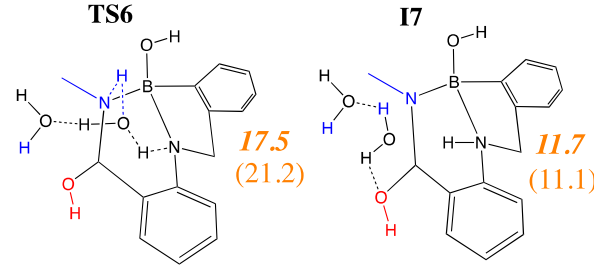

Transfer of proton from amine to aryl amine.
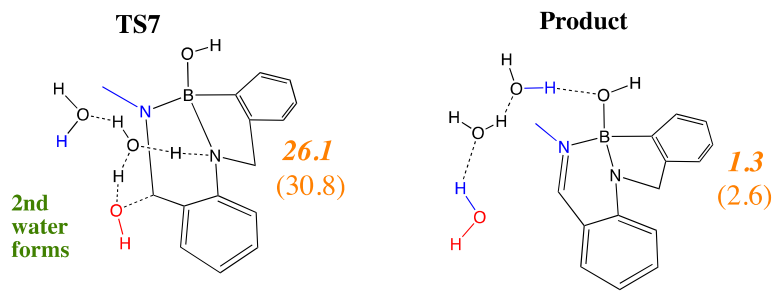

Transfer of proton from aryl amine to alcohol liberating the second water

Figure S1: Relative reaction standard enthalpies computed at $298 \mathrm{~K}$ and $1 \mathrm{~atm}$. SCF energies are included in parenthesis. 


\section{Procedure for Conjugation Reaction with Amines}

${ }^{1} \mathrm{H}$ NMR study

All the conjugation reactions between RMR1 and amines were monitored by ${ }^{1} \mathrm{H}$ NMR. Typically, $10 \mathrm{mM}$ of probe (RMR1) and amine $(10 \mathrm{mM})$ were dissolved in DMSO- $d_{6} / 1 \times$ PBS (containing $10 \% \mathrm{D}_{2} \mathrm{O}$ ) as 2 : 3 ratio. Then, $\mathrm{pH}$ of the reaction mixture was adjusted to 7.4 using $2 \mathrm{~N} \mathrm{HCl}$. After that, the reaction was stirred for about $16 \mathrm{~h}$ to reach the equilibrium. The percentage of the product formation was calculated based on the peak integration of the aldehyde (around $9.9 \mathrm{ppm}$ ) and imine proton (around $8.5 \mathrm{ppm}$ ).

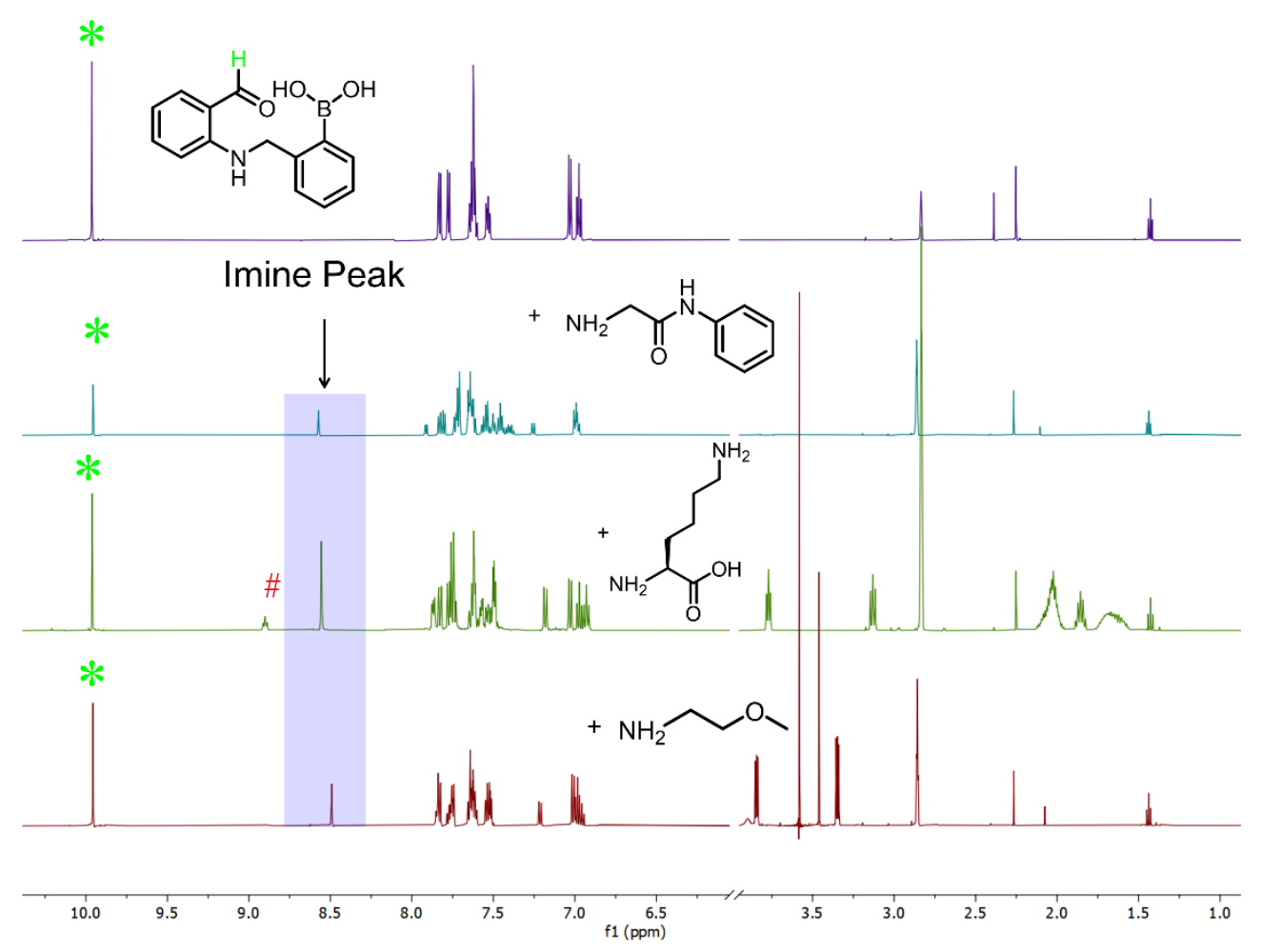

Figure S2: ${ }^{1} \mathrm{H}$ NMR spectra for the conjugation reaction mixture of RMR1 and amines. The green colored asterisks represent the peak for the aldehyde proton from RMR1 and the violet colored box represents the imine proton from the conjugates. The triplet peak at $\sim 8.8 \mathrm{ppm}$ (marked as \#) represents the solvent exchangeable $\mathrm{NH}$ peak from RMR1 molecule. 


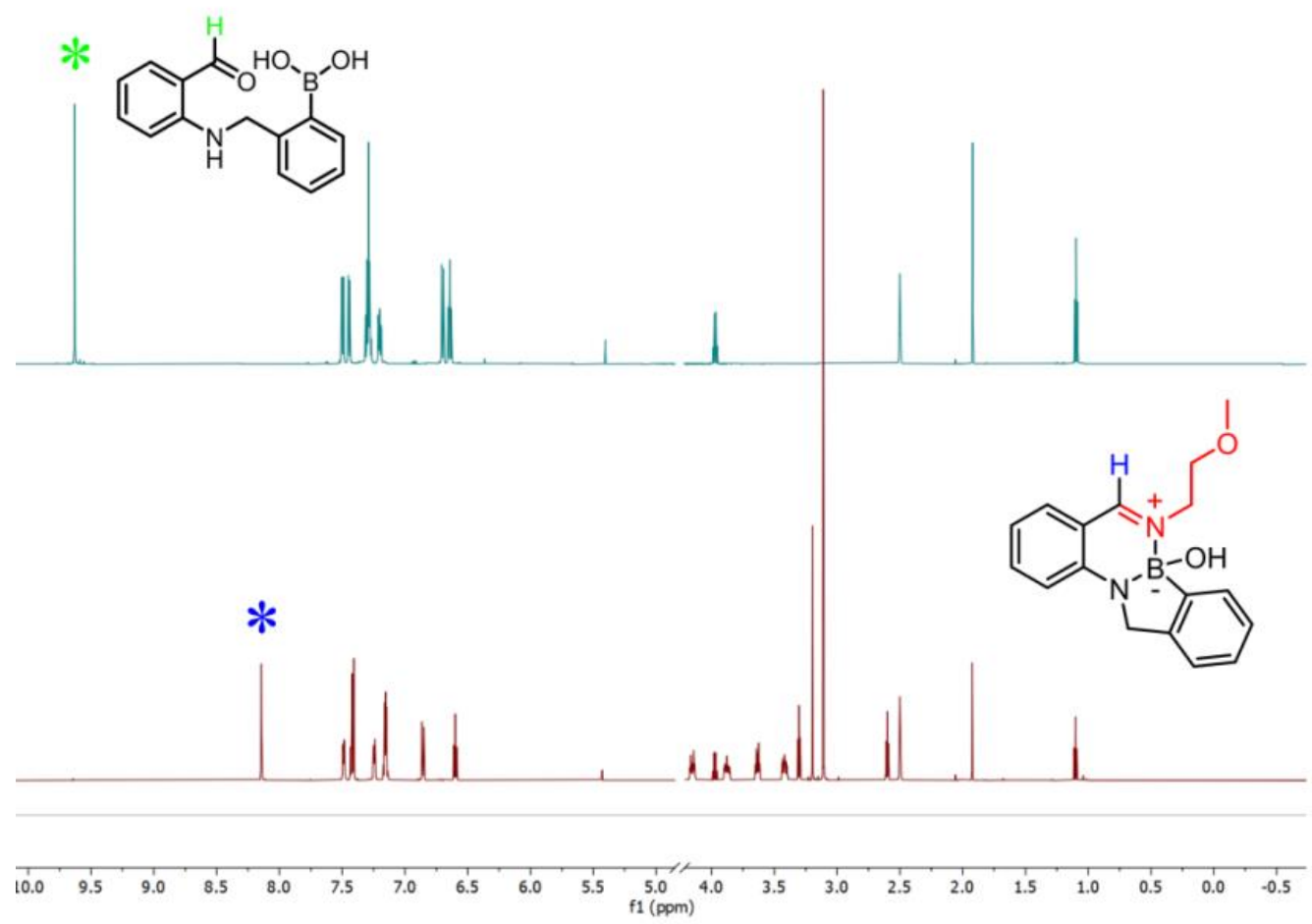

Figure S3: ${ }^{1} \mathrm{H}$ NMR spectra for the conjugation $100 \mathrm{mM}$ reaction mixture of RMR1 and 2-MEA. The green colored asterisk represents the peak for the aldehyde proton from RMR1 and the blue colored asterisk represent the peak of imine proton from the RMR1-2MEA conjugate.

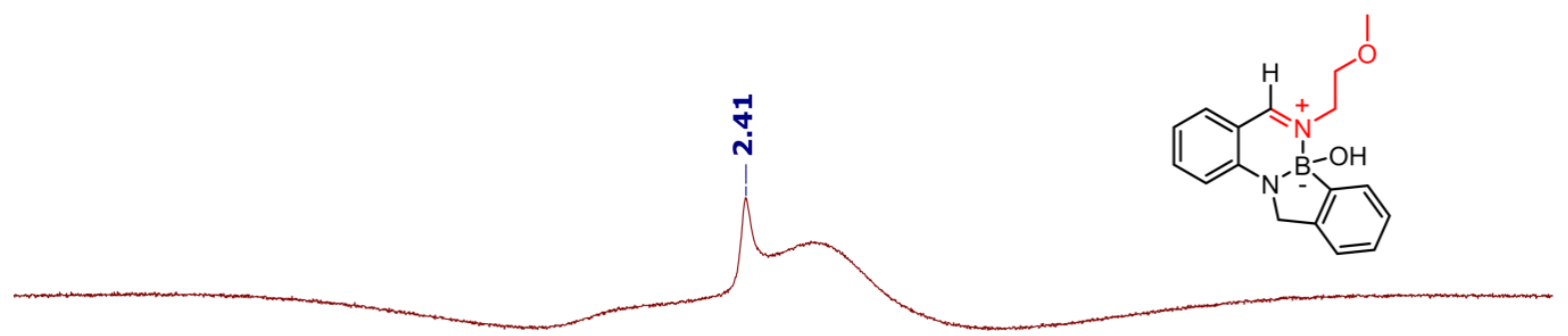

Figure S4: ${ }^{11} \mathrm{~B}$ NMR spectra for the conjugation reaction for mixture of RMR1 (100 mM) and 2$\operatorname{MEA}(100 \mathrm{mM})$. 

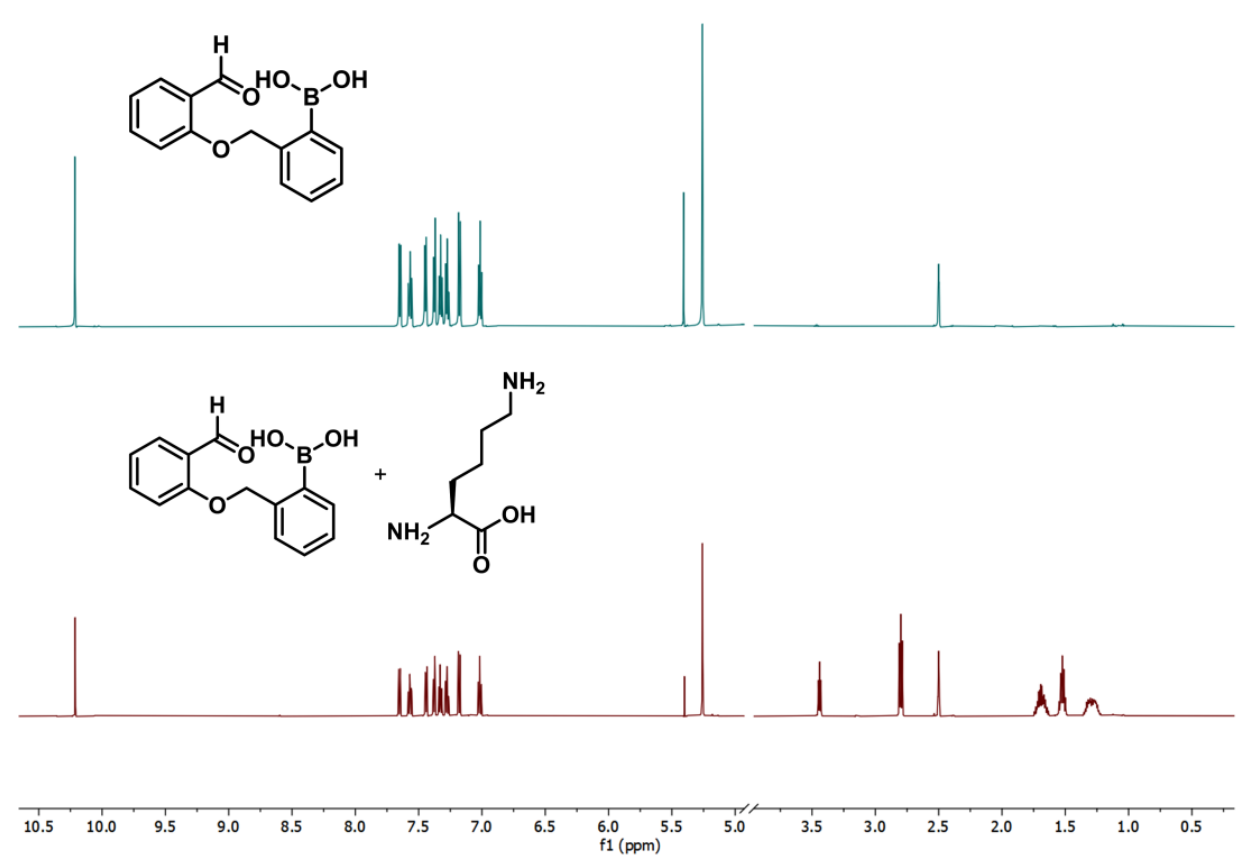

Figure S5: ${ }^{1} \mathrm{H}$ NMR spectra for the reaction mixture of RMR2 and Lys. Reaction condition: 10 $\mathrm{mM}$ reactants were dissolved in DMSO- $d_{d} / 1 \times$ PBS (containing $10 \% \mathrm{D}_{2} \mathrm{O}$ ) as 2: 3 ratio, $16 \mathrm{~h}$, rt.

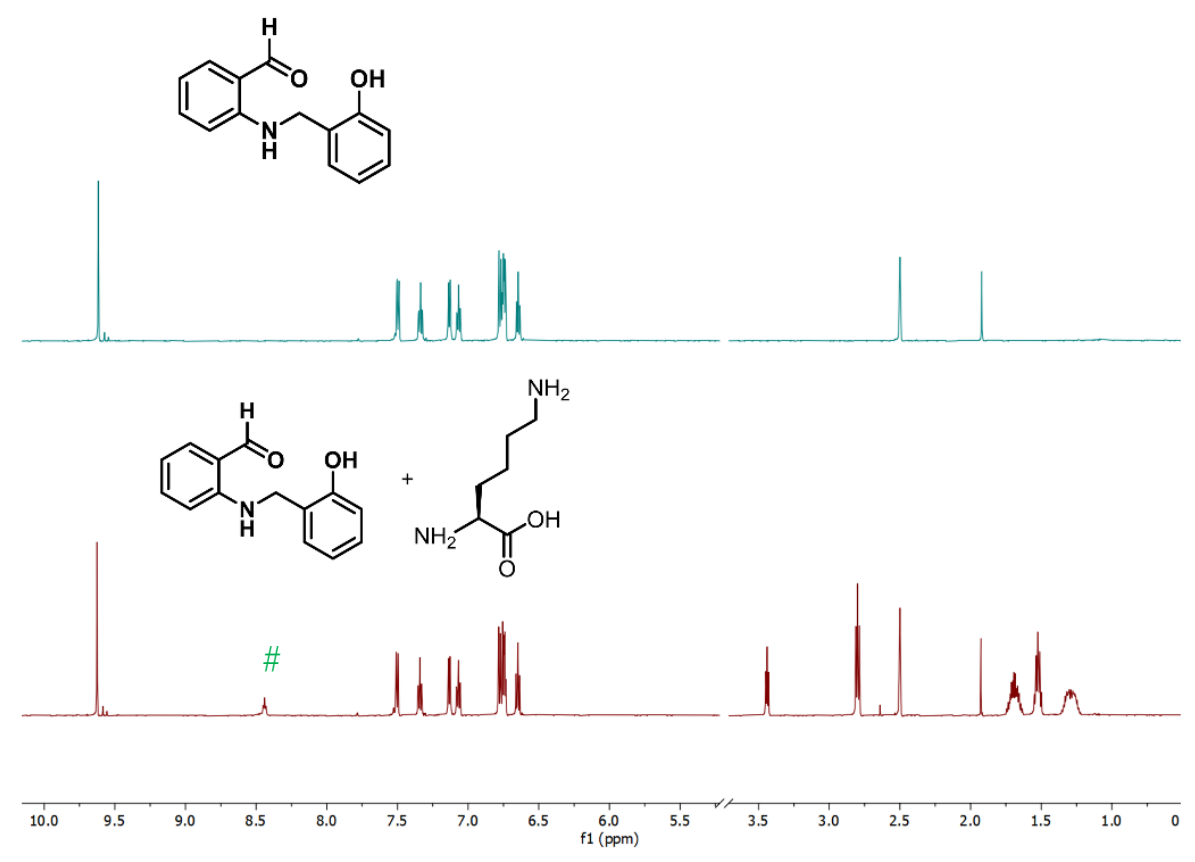

Figure S6: ${ }^{1} \mathrm{H}$ NMR spectra for the reaction mixture of RMR3 and Lys. Reaction condition: 10 $\mathrm{mM}$ reactants were dissolved in DMSO- $d_{6} / 1 \times$ PBS (containing $10 \% \mathrm{D}_{2} \mathrm{O}$ ) as $2: 3$ ratio, $16 \mathrm{~h}$, rt. The triplet peak at $\sim 8.5 \mathrm{ppm}$ (marked as \#) represents the solvent exchangeable $\mathrm{NH}$ peak from RMR3 molecule. 


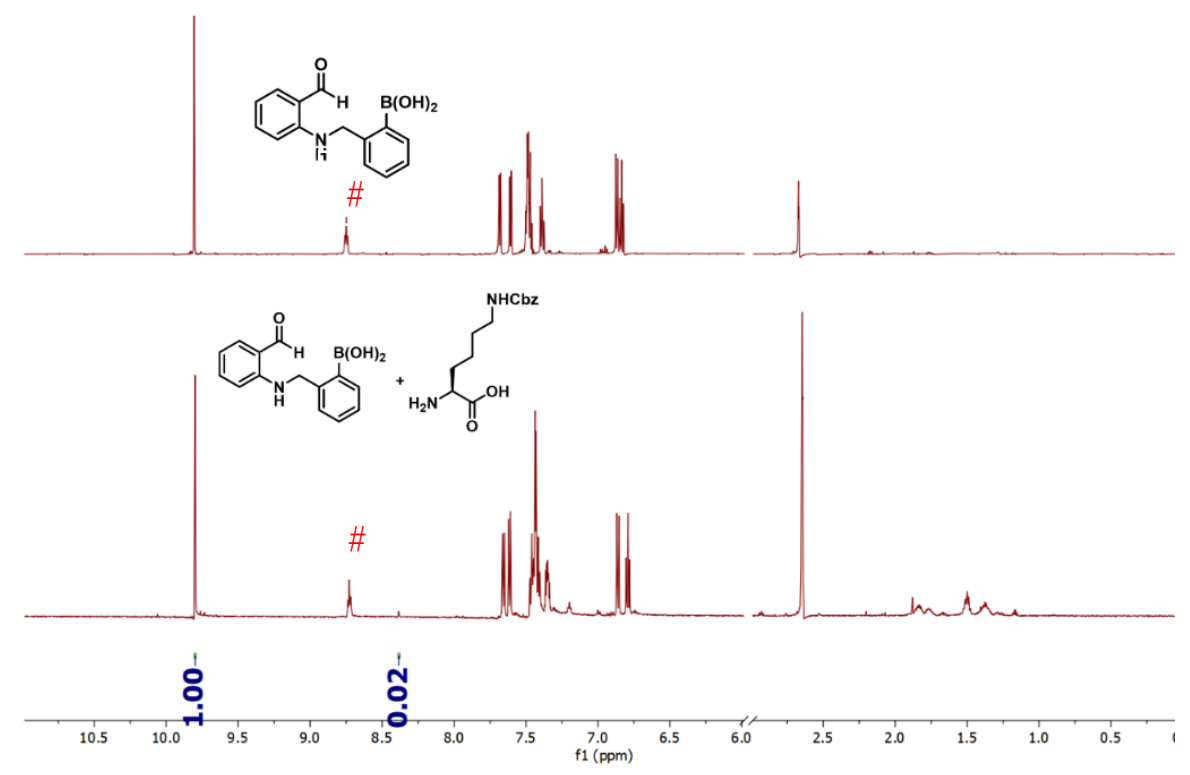

Figure S7: ${ }^{1} \mathrm{H}$ NMR spectra for the reaction mixture of RMR1 and $\mathrm{H}_{2} \mathrm{NLys}(\mathrm{Cbz}) \mathrm{COOH}$. Reaction condition: $10 \mathrm{mM}$ reactants were dissolved in DMSO- $d_{\sigma} / 1 \times$ PBS (containing $10 \% \mathrm{D}_{2} \mathrm{O}$ ) as $2: 3$ ratio, $16 \mathrm{~h}$, rt. The triplet peak at $\sim 8.8 \mathrm{ppm}$ (marked as \#) represents the solvent exchangeable $\mathrm{NH}$ peak from RMR1 molecule. The NMR integration of singlet peak $\sim 8.3 \mathrm{ppm}$ shows $\sim 2 \%$ of the conjugation formation.

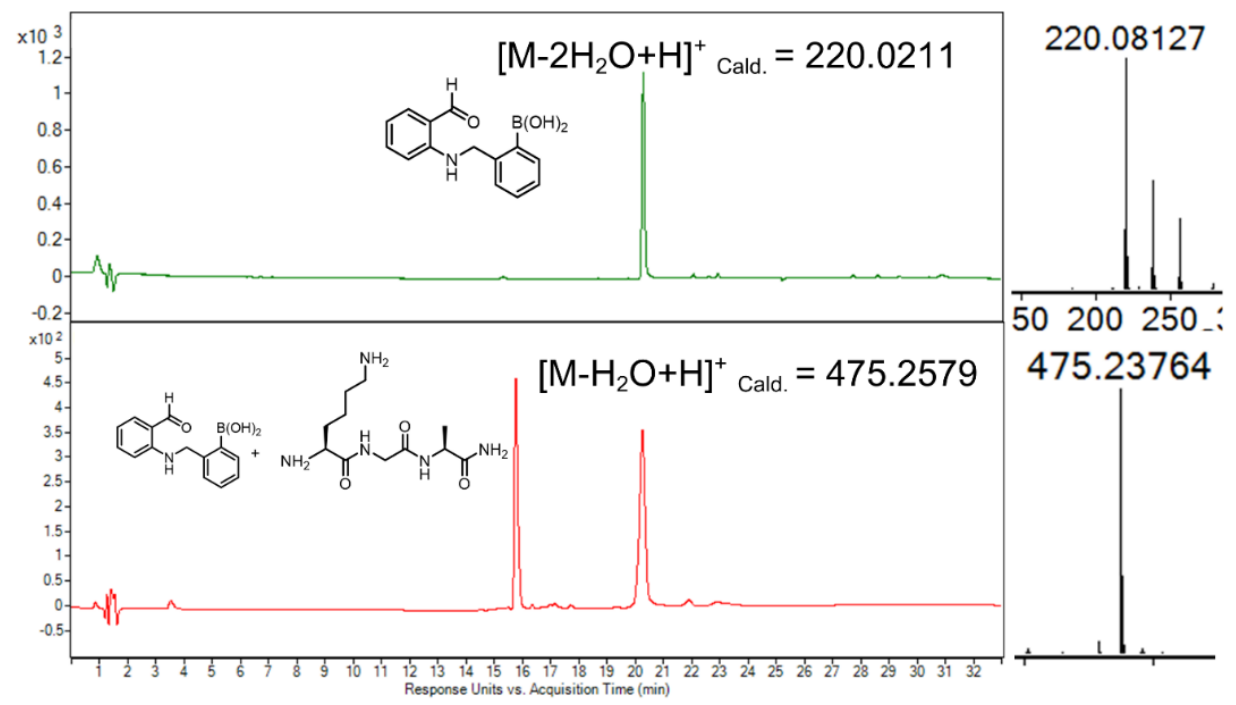

Figure S8: LC-MS trace of the mixture of RMR1 and $\mathrm{H}_{2} \mathrm{~N}$-Lys-Gly-Ala-CONH $\mathrm{H}_{2}$. Reaction condition: $10 \mathrm{mM}$ reactants were dissolved in DMSO- $d_{6} / 1 \times$ PBS (containing $10 \% \mathrm{D}_{2} \mathrm{O}$ ) as 2: 3 ratio, $16 \mathrm{~h}$, rt. A single conjugation product was observed with unreacted RMR1 remaining, consistent with the sluggish reactivity of the a-amine observed in Figure S7. 

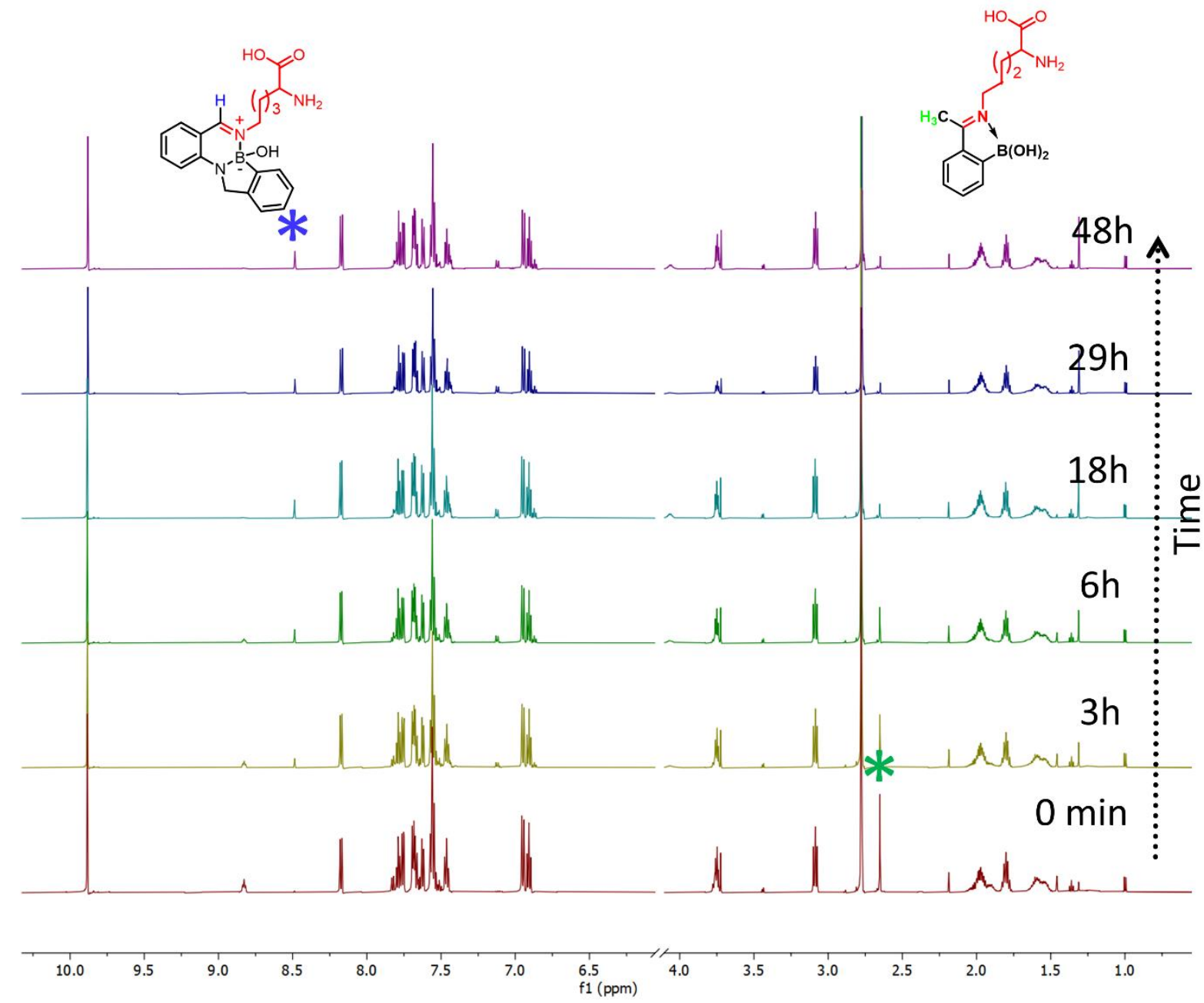

Figure S9: Time dependent ${ }^{1} \mathrm{H}$ NMR spectra for the competing experiment between 2-APBA and RMR1 with Lys. Reaction condition: $10 \mathrm{mM}$ of each reactants were dissolved in DMSO- $d_{6} / 1 \times$ PBS (containing $10 \% \mathrm{D}_{2} \mathrm{O}$ ) as 2: 3 ratio, rt. The iminoboronate (from 2-APBA molecule) decreases from $\sim 28 \%$ to $\sim 5 \%$ and diazaborine (from RMR1) increases from $\sim 0 \%$ to $16 \%$ over the time period of $48 \mathrm{~h}$. 


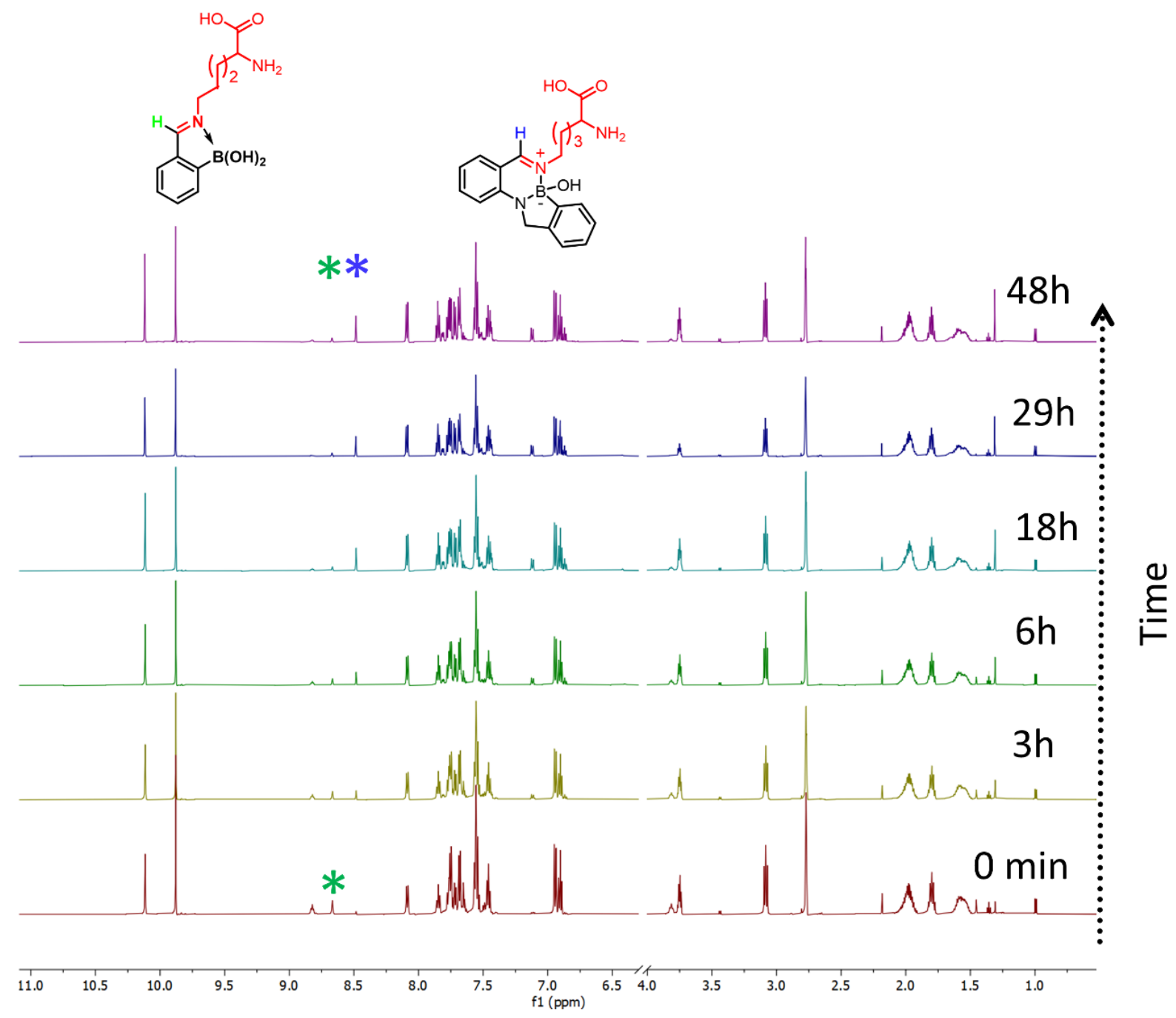

Figure S10: Time dependent ${ }^{1} \mathrm{H}$ NMR spectra for the competing experiment between 2-FPBA and RMR1 with Lys. Reaction condition: $10 \mathrm{mM}$ of each reactants were dissolved in DMSO- $d_{6} / 1$ $\times$ PBS (containing $10 \% \mathrm{D}_{2} \mathrm{O}$ ) as $2: 3$ ratio, rt. The iminoboronate (from 2-FPBA molecule) decreases from $\sim 30 \%$ to $\sim 7.5 \%$ and diazaborine (from RMR 1 ) increases from $\sim 1 \%$ to $\sim 27 \%$ over the time period of $48 \mathrm{~h}$. 


\section{LC-MS Analysis}

The conjugation reaction between RMR1 and amines were further demonstrated by the LC-MS analysis. First, RMR1 $(10 \mathrm{mM})$ and amine $(10 \mathrm{mM})$ were mixed in DMSO/ $1 \times \mathrm{PBS}$ at 2:3 $(\mathrm{v} / \mathrm{v})$ ratio. Then the $\mathrm{pH}$ of medium was adjusted around 7.4 and stirred for about $16 \mathrm{~h}$ to reach the equilibrium. After $16 \mathrm{~h}, 10 \mu \mathrm{L}$ of $100 \mu \mathrm{M}$ reaction mixture (diluted from the $10 \mathrm{mM}$ reaction mixture) was directly injected in LC-MS and the formation of the conjugation was monitored by the UV-Vis trace. The peak for the conjugation product was further confirmed by the ESI-MS analysis. ${ }^{4}$ The LC was run using the Method B mentioned in the instrumentation part.

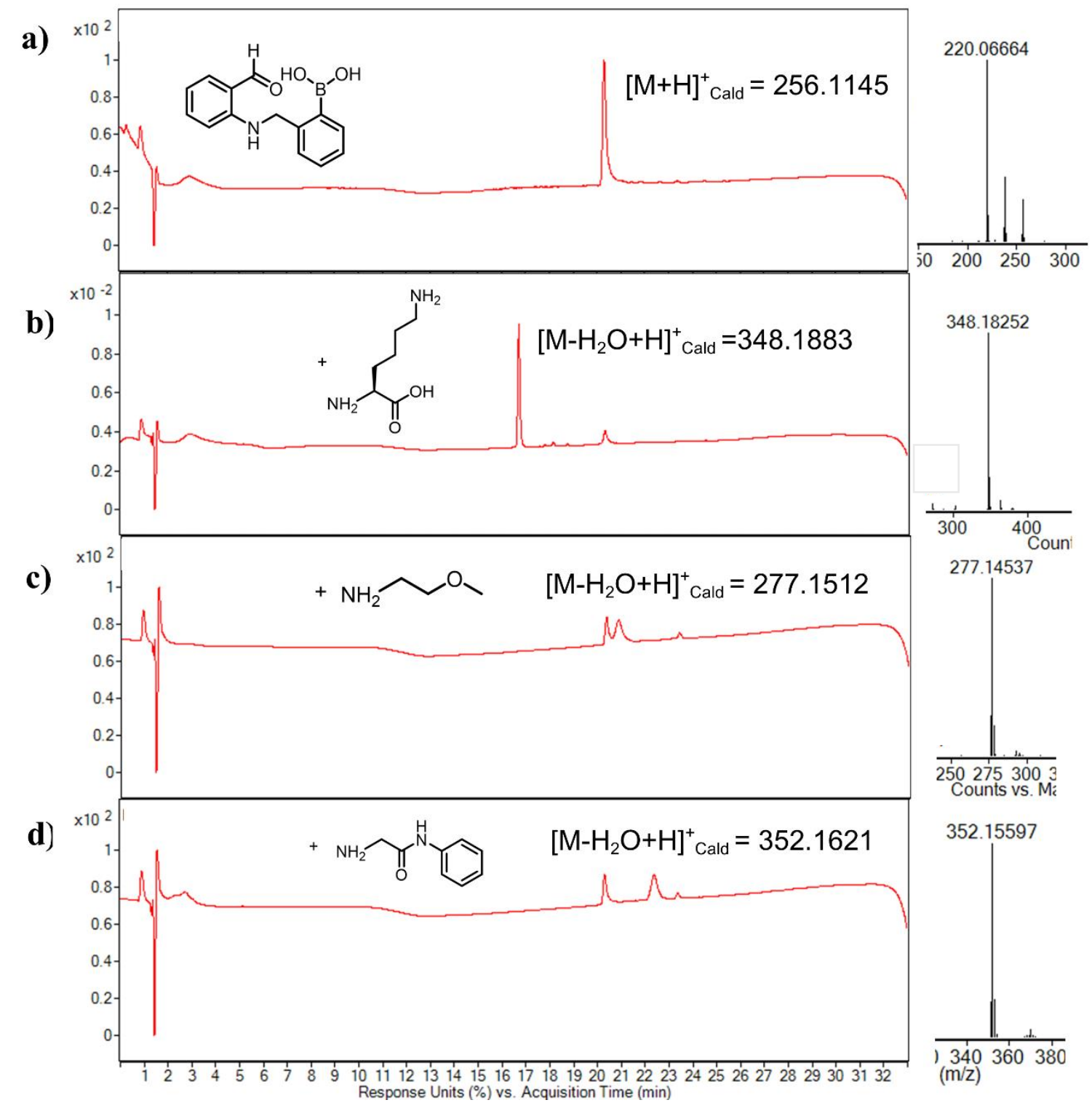

Figure S11: LC-MS analysis of the conjugation reaction between RMR1 and amines (b) Lys (C) 2-MEA (d) $\mathrm{H}_{2} \mathrm{NGlyNHPh}$. The right side of ESI-MS spectra indicates the formation of the diazaborine conjugated product. 


\section{X-Ray Crystal Structure of RMR1-2MEA Conjugate}

First, $100 \mathrm{mM}$ of RMR1 and 2-MEA were mixed together in DMSO- $d_{6} / 1 \times$ PBS (containing $10 \%$ $\mathrm{D}_{2} \mathrm{O}$ ), $\mathrm{pH}$ 7.4. Then, the reaction mixture was stirred for about $16 \mathrm{~h}$ to reach the equilibrium. After $16 \mathrm{~h},{ }^{1} \mathrm{H}$ NMR was recorded. The NMR spectra (Figure S3) indicates the completion of the reaction at $100 \mathrm{mM}$. Then $100 \mathrm{mM}$ conc. of RMR1 and 2-MEA were used for the crystallization trails. The X-ray diffraction quality crystals of RMR1-2MEA conjugate were grown from slow evaporation solution of methanol/water mixture. Briefly, RMR1 (100 mM) and 2-MEA (100mM) was dissolved in $3 \mathrm{~mL}$ of 1:1 Methanol/ Water mixture. Then the $\mathrm{pH}$ of the mixture was adjusted to 7.4 and kept it for slow evaporation. After several days some needle shaped crystals were grown. Bruker AXS SMART APEX CCD diffract meter was used for the collection of the X-ray data using Cu Ka radiation $(\lambda=1.54178 \AA \hat{A})$

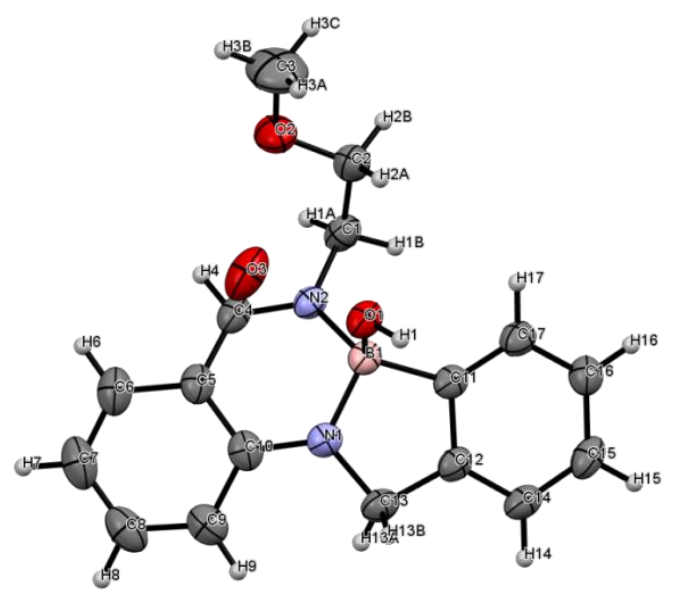

Figure S12: ORTEP diagram of RMR1-2-MEA conjugate. Ellipsoids are drawn at 50\% probability (CCDC No: 2091359).

Table S1: Crystal data and structure refinement for RMR1_2-MEA (CCDC No: 2091359)

Identification code

Empirical formula

Formula weight

Temperature

Wavelength

Crystal system
RMR1_2-MEA

$\mathrm{C}_{17} \mathrm{H}_{19} \mathrm{~B} \mathrm{~N}_{2} \mathrm{O}_{2}, \mathrm{O}$

310.15

173(2) K

$1.54178 \AA$

Orthorhombic 


\begin{tabular}{|c|c|}
\hline Space group & $\mathrm{P}_{\mathrm{bca}}$ \\
\hline Unit cell dimensions & $\begin{array}{l}a=7.9459(2) \AA, b=18.4587(5) \AA, c=22.5948(5) \AA \\
\alpha=90^{\circ}, \beta=90^{\circ}, \gamma=90^{\circ}\end{array}$ \\
\hline Volume & $3314.00(14)$ \\
\hline Z & 8 \\
\hline Density (calculated) & $1.243 \mathrm{~g} / \mathrm{cm}^{-3}$ \\
\hline Absorption coefficient & $0.686 \mathrm{~mm}^{-1}$ \\
\hline$F(000)$ & 1312.0 \\
\hline Crystal size & $0.220 \times 0.120 \times 0.080 \mathrm{~mm}^{3}$ \\
\hline Theta range for data collection & 3.913 to 66.635 \\
\hline Index ranges & $-9<=\mathrm{h}<=9,-21<=\mathrm{k}<=21,-26<=\mathrm{k}<=26$ \\
\hline Reflections collected & 40602 \\
\hline Independent reflections & $40602[\mathrm{R}(\mathrm{int})=0.0786]$ \\
\hline Completeness to theta $=66.635^{\circ}$ & $99.6 \%$ \\
\hline Max. and min. transmission & 0.906 and 0.947 \\
\hline Absorption correction & Semi-empirical from equivalents \\
\hline Refinement method & Full-matrix least-squares on F2 \\
\hline Goodness-of-fit on F2 & 1.030 \\
\hline Data / restraints / parameters & 2916 / $211 / 0$ \\
\hline Final $R$ indices [l>2sigma(I)] & $\begin{array}{l}\mathrm{R} 1=0.0523, w R 2=0.1386 \\
\mathrm{R} 2=0.0734, w R 2=0.1524\end{array}$ \\
\hline Extinction coefficient & $\mathrm{n} / \mathrm{a}$ \\
\hline Largest diff. peak and hole & 0.465 and $-0.174 \mathrm{e} \AA^{-3}$ \\
\hline
\end{tabular}




\section{Procedure for $K_{\mathrm{d}}$ Determination between RMR1 and Amines}

$K_{\mathrm{d}}$ was determined using titration experiment by monitoring the UV-Vis absorption. The UV-Vis absorption was measured using in $2 \mathrm{~mL}$ quartz cuvette (10 $\mathrm{mm}$ path length) at room temperature. First, RMR1 ( $50 \mu \mathrm{M}$ from a stock solution of $2 \mathrm{mM}$ in DMSO) was mixed with the different conc. of amine $(25 \mu \mathrm{M}$ to $50 \mathrm{mM})$ in $1 \times \mathrm{PBS}, \mathrm{pH} 7.4$ and the reaction mixture was stirred for $16 \mathrm{~h}$ to reach the equilibrium. After $16 \mathrm{~h}$, absorbance spectra were recorded. Upon increase the conc. of amine, the peak at $\lambda_{\max } @ 380 \mathrm{~nm}$ gets red shifted. The appearance of new peak at $\lambda_{\max }$ at $423 \mathrm{~nm}$ (for Lys and 2-MEA) and $433 \mathrm{~nm}$ (for $\mathrm{H}_{2} \mathrm{NGlyNHPh}$ ) indicates the formation of the diazaborine conjugated product. All spectra collected during the titration were further background corrected by subtracting the value of the absorbance at $\lambda_{\max }$ at $423 \mathrm{~nm}$ and $433 \mathrm{~nm}$ for RMR1. The curve was then plotted as change in the absorbance at wavelength of $\lambda_{\max }$ at $423 \mathrm{~nm}$ (for Lys and 2$\mathrm{MEA}$ ) and $433 \mathrm{~nm}$ (for $\mathrm{H}_{2} \mathrm{NGlyNHPh}$ ) against the conc. of the amine. Hyperbola equation was used to fit the curve and the $K_{\mathrm{d}}$ values were extracted from the fitted curves.
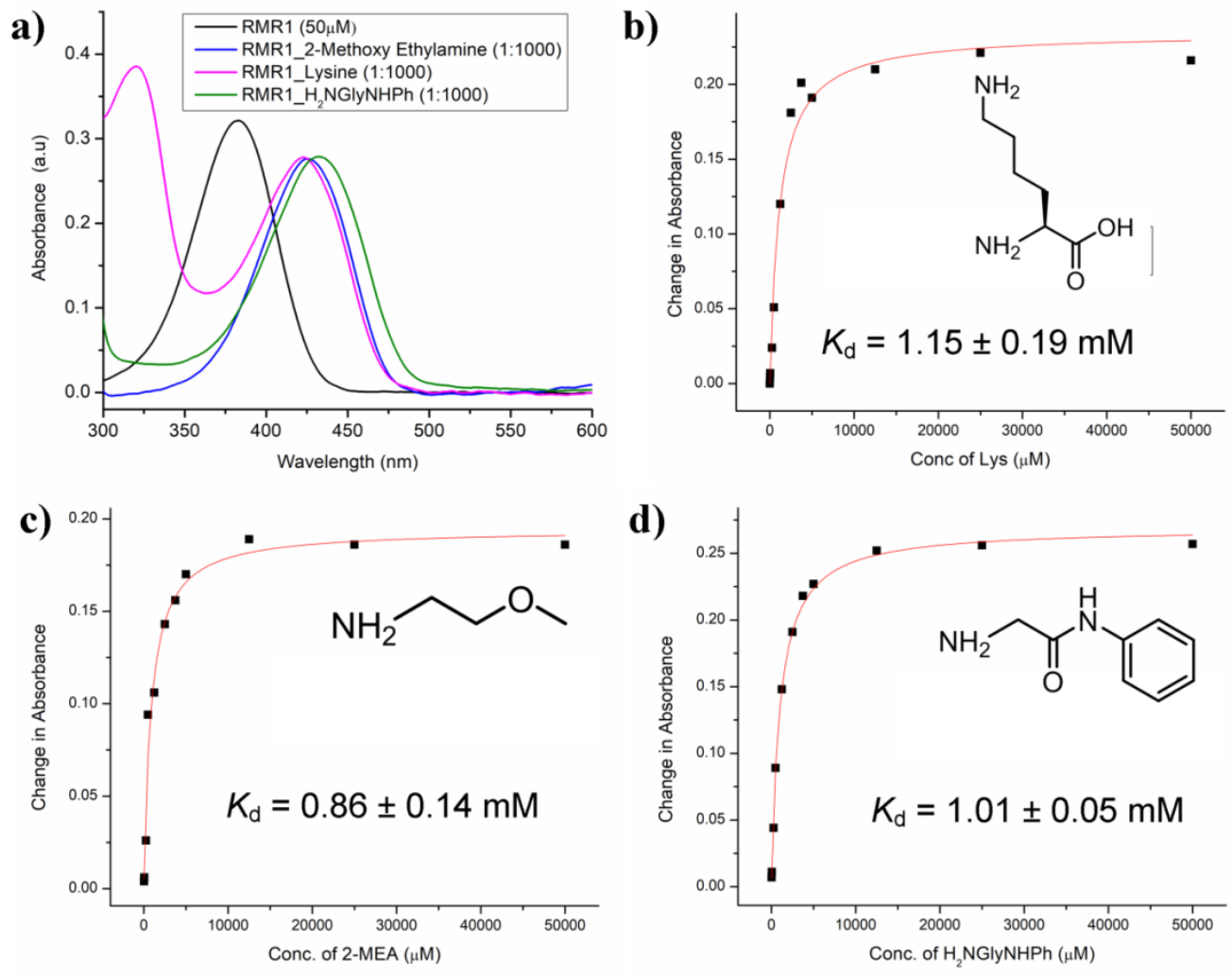

Figure S13: Thermodynamic characterization of the RMR1-amine conjugation. (a) UV-Vis spectra of RMR1 $(50 \mu \mathrm{M})$ and reaction mixture of RMR1 and amines (1:1000 ratio). The red shifted spectrum upon reaction with amines indicates the formation of diazaborine conjugated products. (b)-(d) Titration plot for calculation of $K_{\mathrm{d}}$ for Lys, MEA and $\mathrm{H}_{2} \mathrm{NGlyNHPh}$ respectively. 


\section{Procedure for Determination of Kinetic Parameters}

The kinetic parameters of the conjugation reaction were derived from relaxation kinetics ${ }^{2,5}$ by monitoring the absorbance of dissociation of the conjugated product using UV-Vis spectrometer. All spectra collected during the kinetics experiments were further background corrected by subtracting the absorbance value of RMR1 at $\lambda_{\max }$ at $423 \mathrm{~nm}$ and $433 \mathrm{~nm}$. For the forward reaction rate constant $\left(k_{1}\right)$ was derived from the dissociation rate constant $\left(k_{-1}\right)$ using equations no (i)-(iii). For the dissociation kinetics, dilution experiments were performed. Briefly, 10mM of RMR1 and corresponding amine was mixed in DMSO/1× PBS (2:3), $\mathrm{pH} 7.4$ and stirred for about $16 \mathrm{~h}$ to reach the equilibrium. After the equilibrium is reached, reaction mixture was diluted to $50 \mu \mathrm{M}$ and the

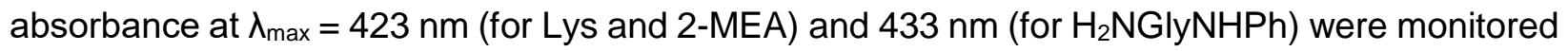
over the time. The data was then fitted with the following equations and dissociation rate constant $k_{-1}$ was calculated. Equations used for calculation of the kinetic parameters are as following

$$
\begin{aligned}
& \mathrm{A}+\mathrm{B} \frac{k_{1}}{k_{-1}} \mathrm{C} \\
& Y=Y_{0}+A e^{-t / \tau} \\
& \tau=\frac{1}{\left\{k_{-1}+k_{1} \times([A]+[B])\right\}} . \\
& K_{d}=k_{-1} / k_{1}
\end{aligned}
$$

Where,

$$
\begin{aligned}
& \tau=\text { Relaxation time } \\
& k_{1}=\text { Rate of the forward reaction } \\
& k_{-1}=\text { Rate of the backward reaction } \\
& K_{d}=\text { Dissociation constant }
\end{aligned}
$$

$[\mathrm{A}]$ and $[\mathrm{B}]$ are conc. of $\mathrm{RMR} 1$ and amines in reaction mixture respectively.

The dilution experiment for the dissociation kinetics was further validated using ${ }^{1} \mathrm{H}$ NMR spectroscopy. Briefly, RMR1 and corresponding amines were mixed at conc. of $10 \mathrm{mM}$ in DMSO$d_{6} / 1 \times$ PBS (containing $10 \% \mathrm{D}_{2} \mathrm{O}$ ), $\mathrm{pH} 7.4$. Then, the reaction mixtures were stirred for about $16 \mathrm{~h}$ to reach the equilibrium. After the equilibrium is reached, reaction mixtures were diluted to 0.5 $\mathrm{mM}$ in $1 \times \mathrm{PBS} \mathrm{pH}$ 7.4. Then ${ }^{1} \mathrm{H}$ NMR was recorded at different time points. The percentage yield of the conjugation was calculated based on the integration of the imine proton peak (around 8.5 ppm) and aldehyde proton peak (around 9.9 ppm). 

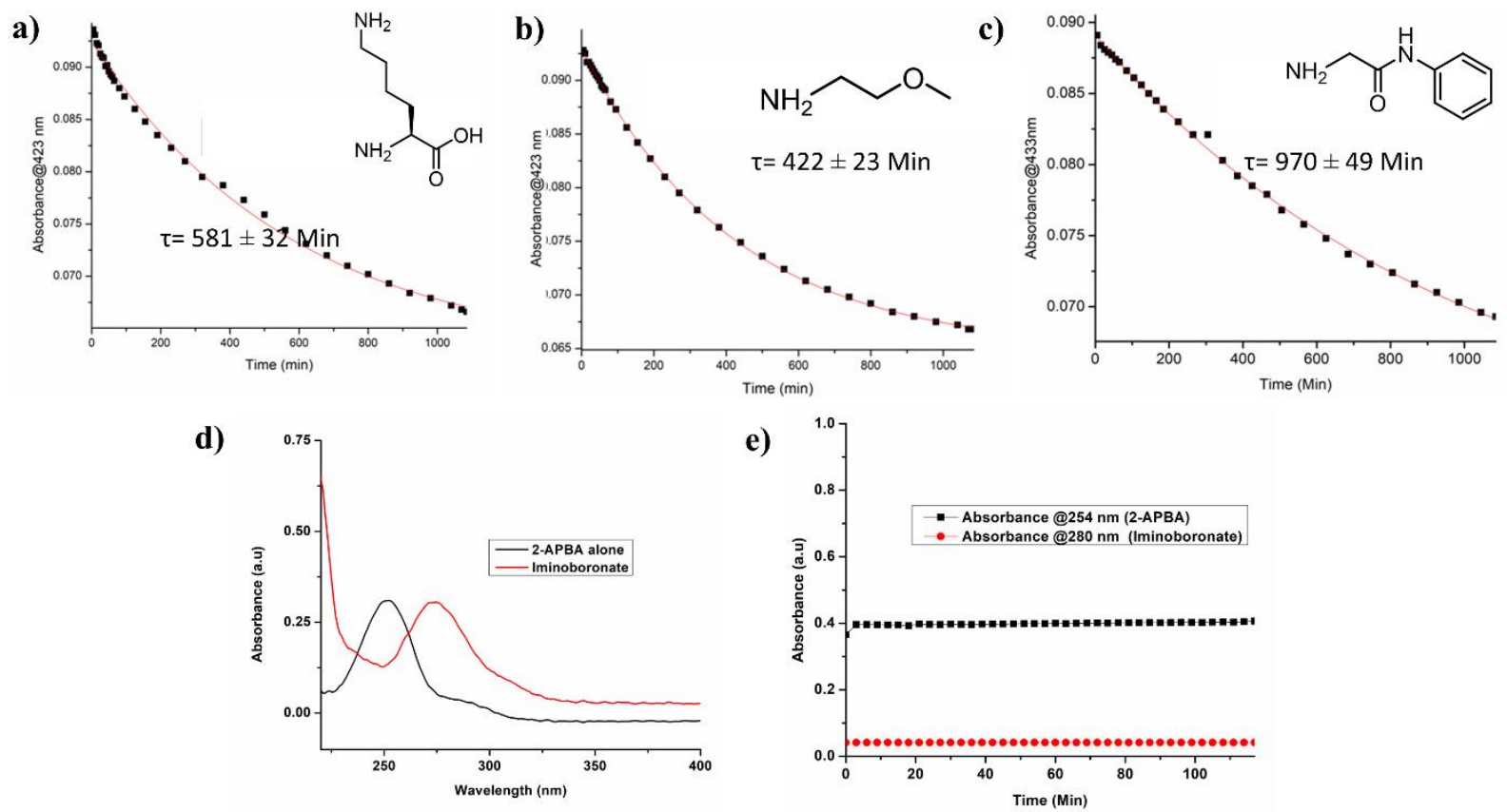

Figure S14: Dissociation kinetics recorded by diluting the conjugate of RMR1 with (a) Lys, (b) 2 MEA, and (c) $\mathrm{H}_{2} \mathrm{NGlyNHPh}$ respectively. The dissociation was recorded by monitoring the UV-vis absorption of the diazaborines. Also shown for comparison is the dissociation kinetics of the iminoboronate conjugate of APBA and lysine, with the UV-vis absorption spectra shown in (d) and kinetic trace shown in (e). All dilutions were from $10 \mathrm{mM}$ to $50 \mu \mathrm{M}$. These results collectively demonstrate the instantaneous dissociation of the iminoboronate in contrast to the slow dissociation of the diazaborines. 


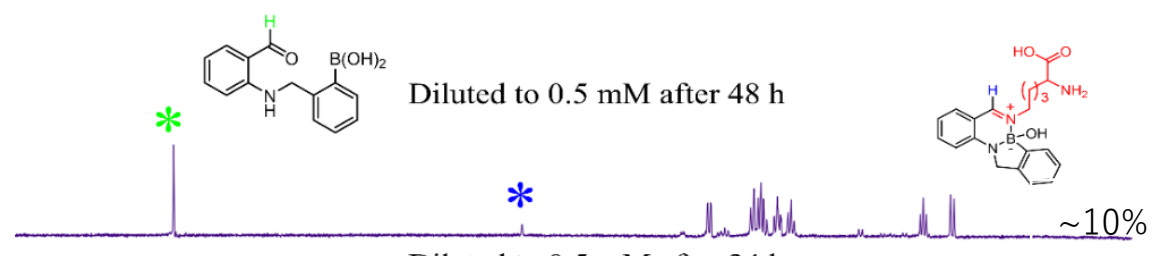

Diluted to $0.5 \mathrm{mM}$ after $24 \mathrm{~h}$

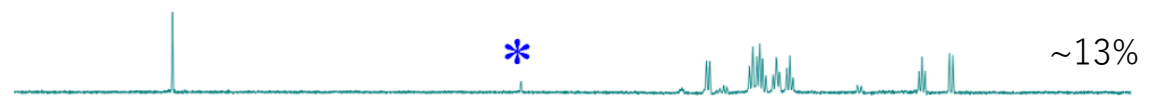

Diluted to $0.5 \mathrm{mM}$ after $12 \mathrm{~h}$

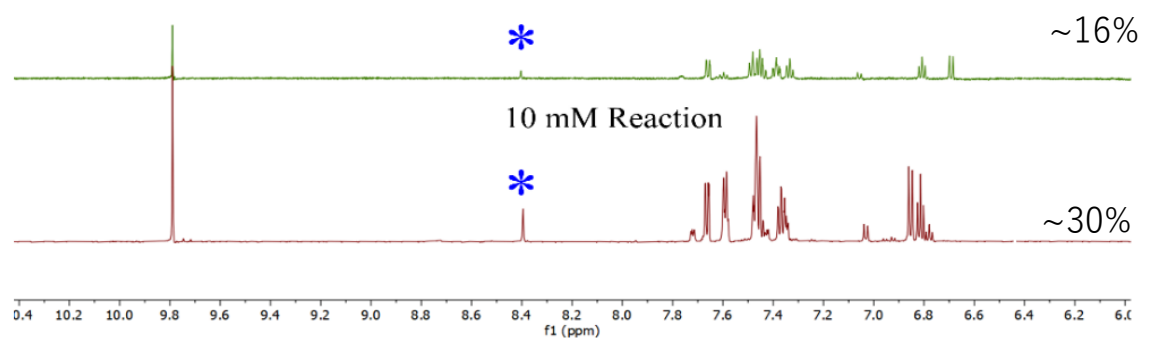

Figure S15: ${ }^{1} \mathrm{H}$ NMR spectra for the dilution experiment to show the reversibility of RMR1-Lys conjugation reaction. The \% of the diazaborine conjugate, determined from integration of NMR spectra, is shown on each spectrum.

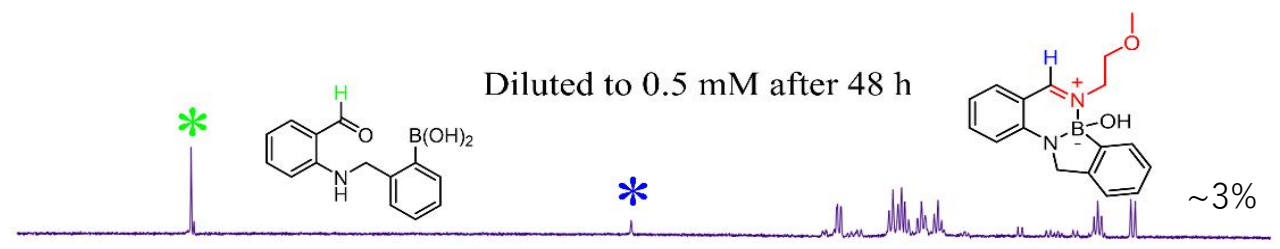

Diluted to $0.5 \mathrm{mM}$ after $24 \mathrm{~h}$

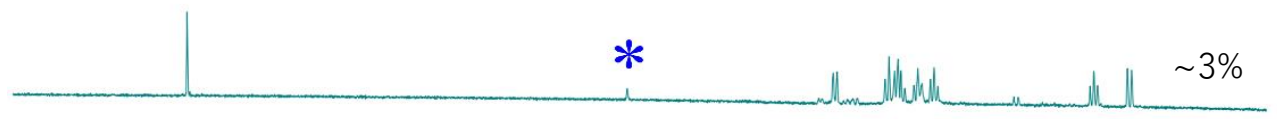

Diluted to $0.5 \mathrm{mM}$ after $12 \mathrm{~h}$
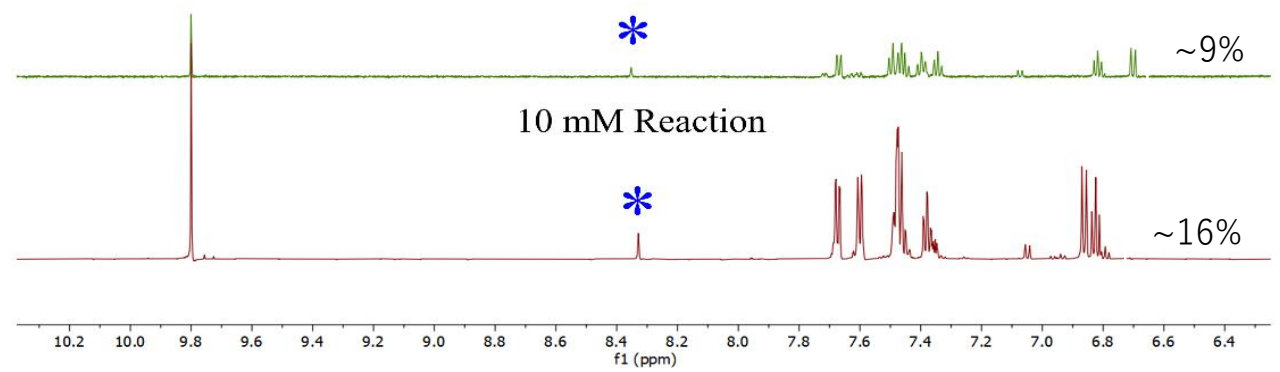

Figure S16: ${ }^{1} \mathrm{H}$ NMR spectra for the dilution experiment to show the reversibility of RMR1-2MEA conjugation reaction. The $\%$ of the diazaborine conjugate, determined from integration of NMR spectra, is shown on each spectrum. 


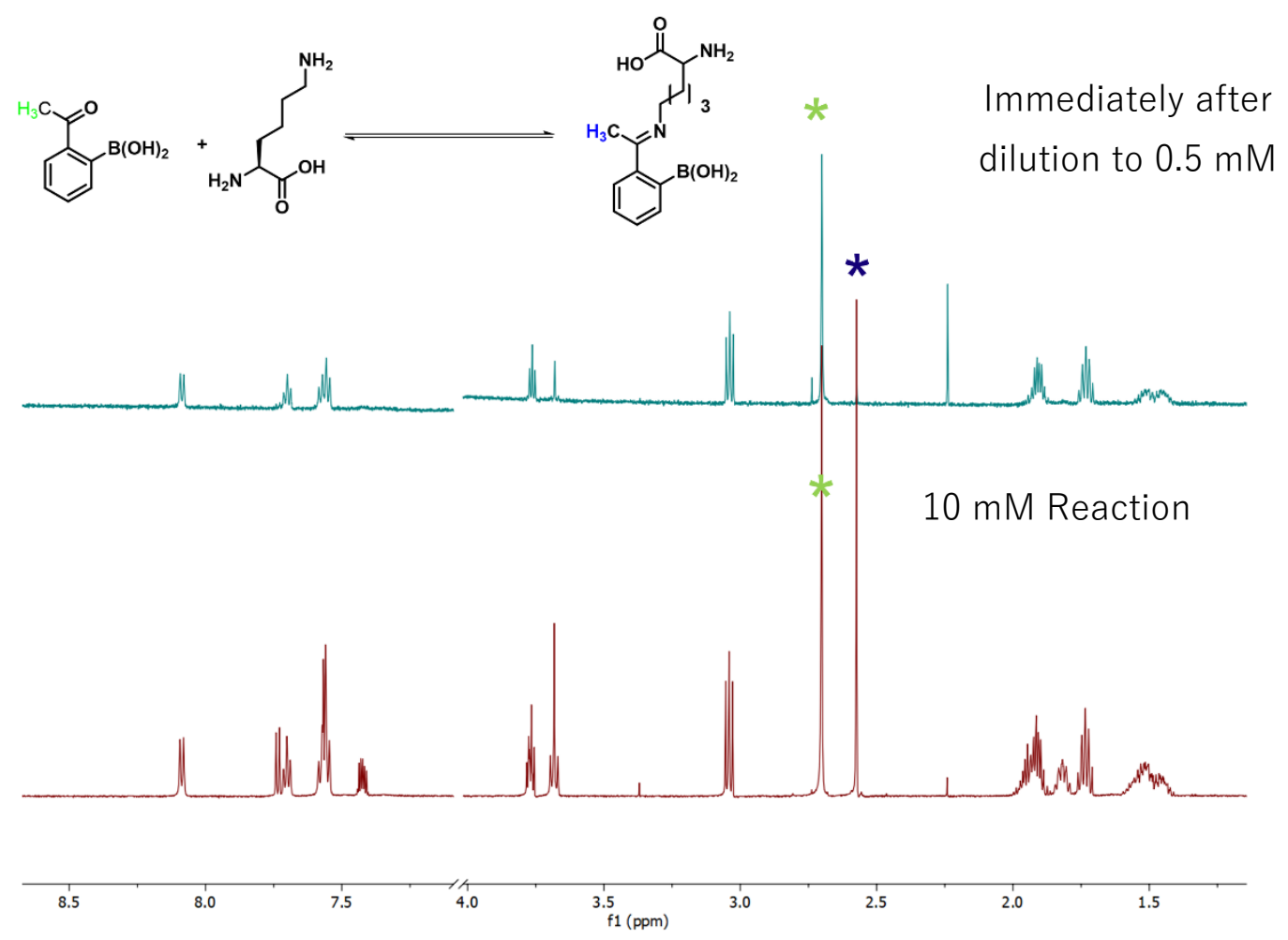

Figure S17: ${ }^{1} \mathrm{H}$ NMR spectra for the dilution experiment to show the instantaneous reversibility of APBA-Lys conjugation reaction. The ${ }^{1} \mathrm{H}$ NMR spectra were taken before and immediately after dilution to $0.5 \mathrm{mM}$. The disappearance of the iminoboronate acetyl peak demonstrates the fast kinetics of iminoboronate dissociation.

\section{Peptide Synthesis}

All the peptides were synthesized on solid support of Rink amide resin on $0.1 \mathrm{mmol}$ scale using standard Fmoc based peptide synthesis chemistry. All coupling reactions were carried out in DMF solvent using HBTU as coupling reagents, $0.4 \mathrm{~N}$-Methyl Morpholine in DMF as base. After each coupling, for the deprotection of the Fmoc group was done by using $20 \%$ piperidine in DMF. Alloc group was deprotected on $\mathrm{N}$-terminal Fmoc protected resin $(0.025 \mathrm{mmol})$ using $\mathrm{Pd}\left(\mathrm{PPh}_{3}\right)_{3} / \mathrm{PhSiH}_{3}$ in DCM. After that the resins were thoroughly washed with DMF and DCM. Then 5(6)Carboxyfluorescein or APBA-Acid or RMR1-Acid was coupled with Dap residue using HBTU as a coupling reagent and 0.4 N-Methyl Morpholine in DMF as a base. After completion of the coupling, $\mathrm{N}$-Terminal Fmoc was deprotected and peptides were cleaved from resin using Reagent B. Then, the crude peptide was filtered through sintered glass funnel and precipitated out slowly by adding cold diethyl ether at $0{ }^{\circ} \mathrm{C}$ to give a solid product. For disulfide formation, crude peptide was dissolved in $\mathrm{NH}_{4} \mathrm{CO}_{3}$ buffer $(20 \mathrm{mM}, \mathrm{pH} 8$, peptide concentration $2 \mathrm{mM}$ ) and stirred for $12 \mathrm{~h}$ in an open flask. After completion of the reaction (confirmed by LC-MS analysis), cyclic peptides were purified by reverse phase HPLC on a $\mathrm{C} 18$ column using $\mathrm{ACN} / \mathrm{H}_{2} \mathrm{O}$ (with $0.1 \%$ TFA) gradient 
system. The acylation of the N-terminal of peptide P5 was carried out on purified N-terminal free P5 using 1 equivalent of acetic anhydride/pyridine in DMF. The purity of these peptides was further confirmed by LC-MS analysis (Method A mentioned in the instrument part was used for the analysis). Final pure peptides were lyophilized to get solid compound which was used for the different binding assays on protein and bacterial cells.

\section{Expression of Sortase A}

Sortase A plasmid of S. aureus was obtained from Addgene (pET28a-SrtAdelta59). The Sortase A over expression plasmid construct was transformed into the Escherichia coli strain BL21(DE3). For protein expression, the Sortase A plasmid contained E. coli BL21(DE3) was cultured in 1L of LB media containing $50 \mu \mathrm{g} / \mathrm{mL}$ kanamycin at $37^{\circ} \mathrm{C}$ with vigorous shaking until the O.D. reaches 0.5-0.8. The production of Sortase A was then induced with $1 \mathrm{mM}$ IPTG for about $16 \mathrm{~h}$ incubation with vigorous shaking at room temperature. Then, the cells were harvested by centrifugation (5000 rpm for $20 \mathrm{~min}$ ). The cell pallet was resuspended in $15 \mathrm{~mL}$ lysis buffer (containing $10 \mathrm{mM}$ imidazole, $20 \mathrm{mM}$ Tris, $300 \mathrm{mM} \mathrm{NaCl}$ ) and lysied by sonication. The lysate is clarified by centrifugation at $7000 \mathrm{rpm}$ for 40 min before purification with Ni-NTA agarose column and pd-10 desalting column. Furthermore, the purity of the Sortase a was confirmed by the LC-MS analysis (Method C mentioned in the instrumentation part was used)

Sequence of the expressed protein

MRGSSHHHHHHSSGLVPRGSHMQAKPQIPKDKSKVAGYIEIPDADIKEPVYPGPATPEQLNRG VSFAEENESLDDQNISIAGHTFIDRPNYQFTNLKAAKKGSMVYFKVGNETRKYKMTSIRDVKPT DVGVLDEQKGKDKQLTLITCDDYNEKTGVWEKRKIFVATEVK

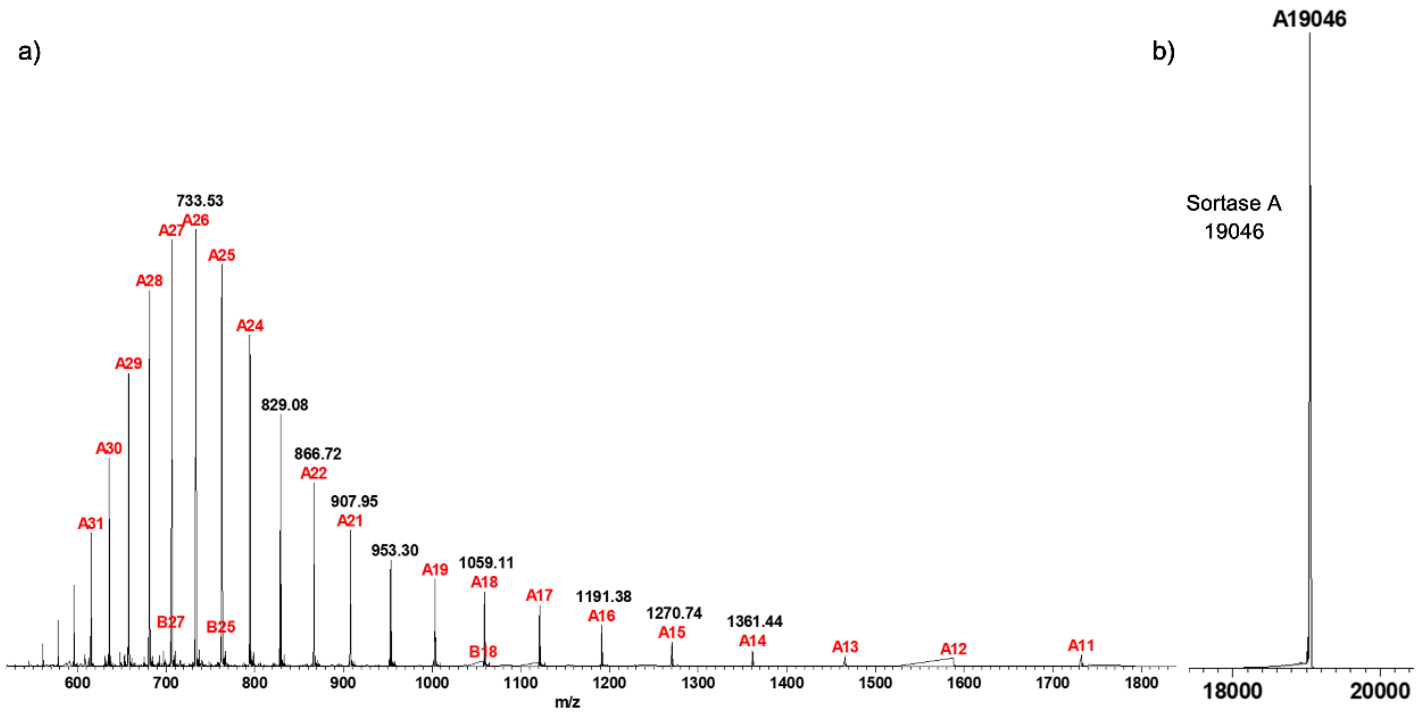

Figure S18: LC-MS data of Sortase A indicating the purity of the protein (a) and (b) are convoluted and deconvoluted mass spectra of Sortase A respectively. 


\section{Biotinylation of Sortase A}

The Sortase A was biotinylated by incubation of $300 \mu \mathrm{M}$ of protein in $1 \times$ DPBS, pH 7.4 with BiotinNHS $(300 \mu \mathrm{M})$ for about $16 \mathrm{~h}$ at $4^{\circ} \mathrm{C}$. The biotinylation of Sortase A was further confirmed by LCMS. analysis.

a)

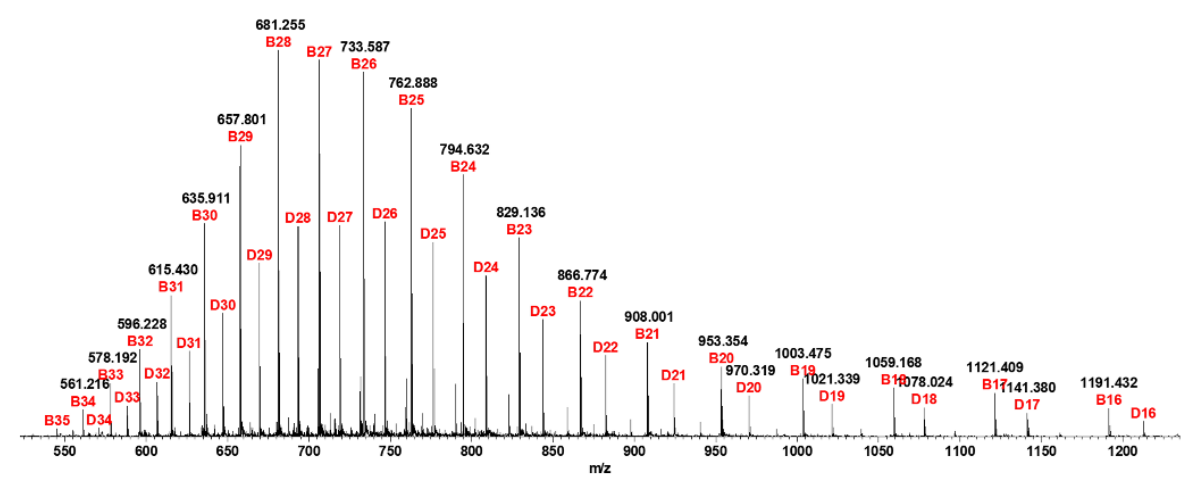

b)

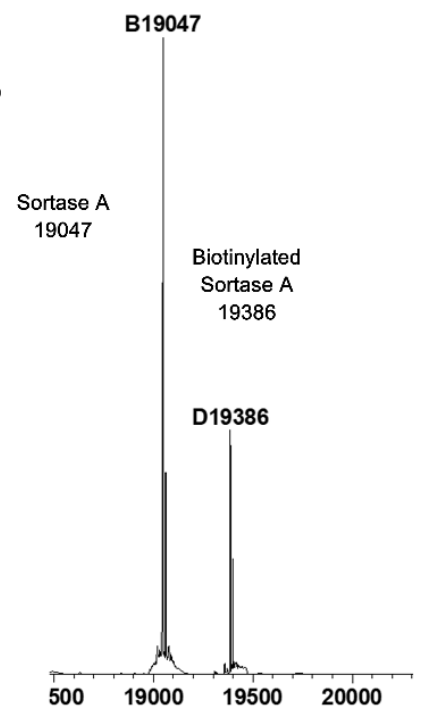

Figure S19: LC-MS data of biotinylated Sortase A. (a) and (b) are convoluted and deconvoluted mass spectra of biotinylated Sortase A respectively. The labeling reaction with Biotin-NHS yielded $\sim 30 \%$ mono-biotinylated protein and a small amount of double biotinylated sortase. 


\section{Procedure for Phage Display Screening}

The phage library was blocked in $200 \mu \mathrm{L}$ of $1 \times$ DPBS containing $1 \% \mathrm{w} / \mathrm{v} \mathrm{BSA}$ and $0.1 \% \mathrm{v} / \mathrm{v}$ Tween 20 for $30 \mathrm{~min}$. Biotinylated Sortase A was immobilized on $20 \mu \mathrm{L}$ magnetic streptavidin beads (Dynabeads M-280, Invitrogen Dynal Biotech) in $200 \mu \mathrm{L}$ of $1 \times$ DPBS with $1 \% \mathrm{w} / \mathrm{v}$ BSA and $0.1 \%$ $\mathrm{v} / \mathrm{v}$ Tween 20 for $30 \mathrm{~min}$. The Sortase A immobilized beads were washed three times with $1 \mathrm{~mL}$ of $1 \times$ DPBS. The blocked phage was added to the Sortase A coated beads and incubated for another $30 \mathrm{~min}$. Then, the beads were washed 10 times with $1 \mathrm{~mL} 1 \times$ DPBS with $0.1 \% \mathrm{v} / \mathrm{v}$ Tween20. The phage bound to the beads were eluted by $900 \mu \mathrm{L} 150 \mathrm{mM}$ glycine, $\mathrm{pH} 2$ for $10 \mathrm{~min}$. the eluted phage is then neutralized with $90 \mu \mathrm{L}$ of $1.5 \mathrm{M}$ Tris $\mathrm{pH} 8.8$. The eluted phage was again incubated with $20 \mathrm{~mL}$ exponentially growing E.coli 2738 in LB media for about $4.5 \mathrm{~h}$. Then the cells were harvested by centrifugation and the amplified phage in the supernatant was precipitated with $18.8 \% \mathrm{~V} / \mathrm{V} \mathrm{PEG} / \mathrm{NaCl}$ and resuspended in $1 \times$ DPBS for the next round screening. After three rounds of panning we found the hit peptide W7 (ACLIPTWGGC)

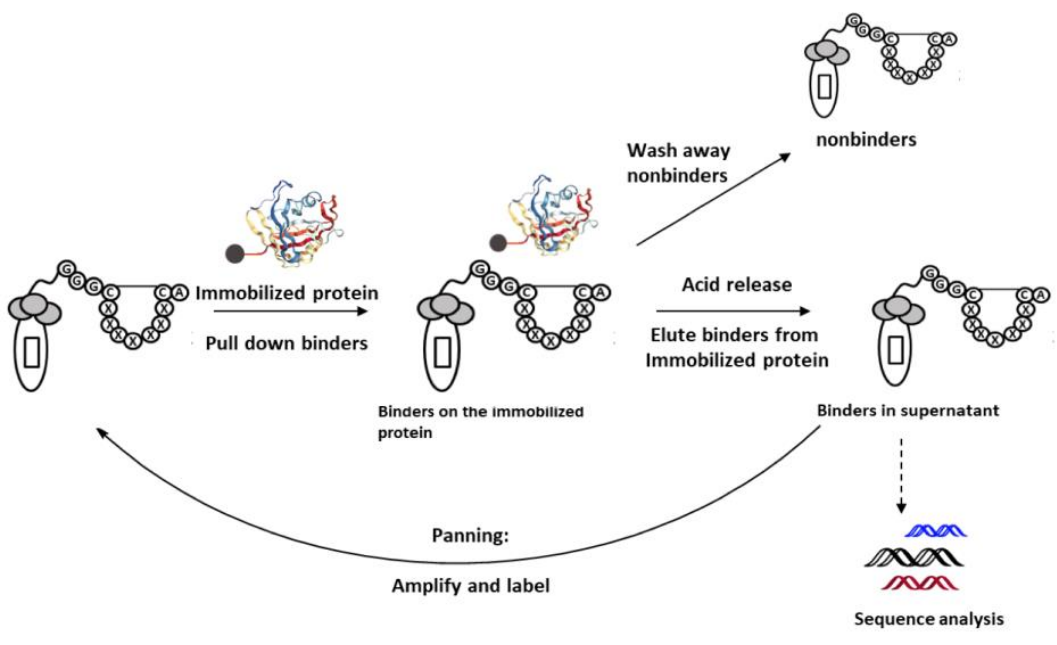

Figure S20: Schematic representation of panning against Sortase $A$ using $\mathrm{CX}_{7} \mathrm{C}$ phage library. 


\section{Procedure for Binding Assay between W7-F and Sortase A}

The binding assay of peptide W7-F (with Sortase A was determined by the fluorescence polarization experiment. The assay was performed using peptide W7-F at a final conc. of $200 \mathrm{nM}$ and incubated with increasing conc. of Sortase A (35 nM to $36 \mu \mathrm{M})$ in 1× DPBS, pH 7.4 for 30 $\min$. After that, fluorescence polarizations were recorded by excitation at $485 \mathrm{~nm}$ and recording emission at $535 \mathrm{~nm}$. Then the fluorescence polarization value was plotted against conc. of Sortase A. Furthermore, the curve was fitted using the following equation and $K_{d}$ value was extracted from the fitted curve. The experiments were carried out in triplicate and plotted as an average of three trials with standard deviations.

$$
y=F P_{\min }+\left(F P_{\max }-F P_{\min }\right)^{*}\left(K_{d}+L s t+X-s q r t\left(\left(K_{d}+L s t+x\right)^{\wedge} 2-4^{*} L s t^{*} x\right)\right) /\left(2^{*} L s t\right)
$$

Where,

$\mathrm{FP}_{\text {min }}=$ Lowest value of fluorescence polarization in the binding curve experiment $\mathrm{FP}_{\max }=$ Highest value of fluorescence polarization in the binding curve experiment $K_{d}=$ Dissociation constant for binding of peptide W7-F and Sortase A.

Lst= Conc. of W7-F peptide i.e. $200 \mathrm{nM}$

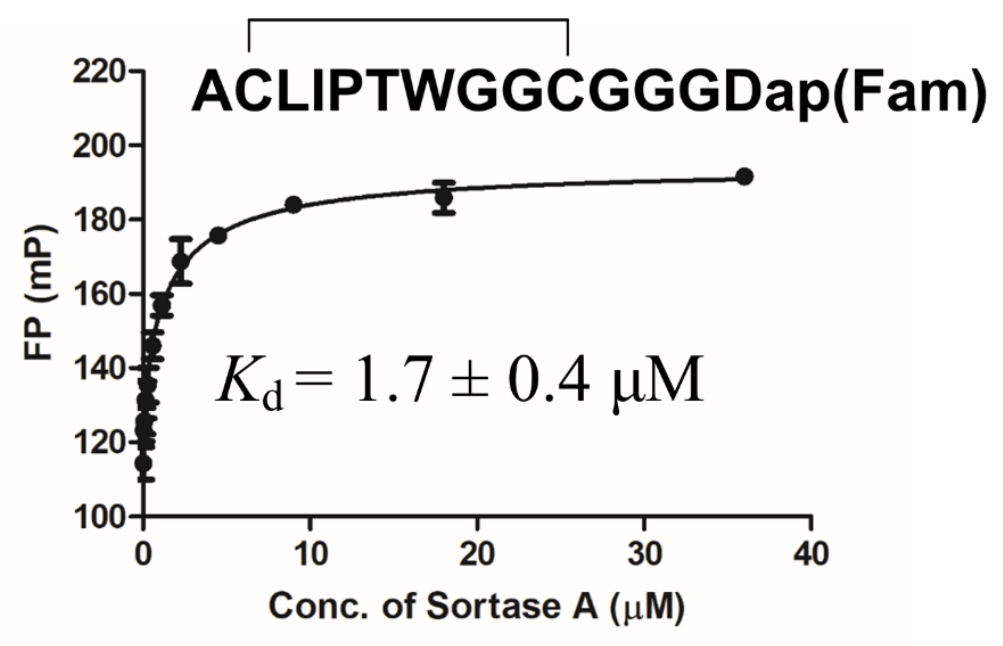

Figure S21: Binding curve between peptide W7-F and Sortase A. 


\section{Molecular Docking Calculations for Binding of Peptide W7 with Sortase A}

A model of the cyclic peptide W7 was prepared using the Avogadro program and saved in pdbfile format. The Auto Dock Tool utility program prepare_ligand4.py ( $v 1.10)$ was used to create the ligand input file for the docking calculations in pdb qt file format. The Sortase A receptor structure was prepared from the Brookhaven Protein Databank file with code 1T2W. The protein crystal structure consists of a trimeric complex with subunits $A, B$, and $C$. The $B$ and $C$ units were discarded. The pentapeptide LPETG was removed from the active site of unit A. The molecular docking program Vina ${ }^{6}$ (AutoDockVina 1.1.2 (May 11, 2011) was used for the molecular docking calculations. The molecular docking space was chosen to 40 by 40 by $40 \AA$, encompassing the entire receptor. All molecular docking parameters were set to their default values.
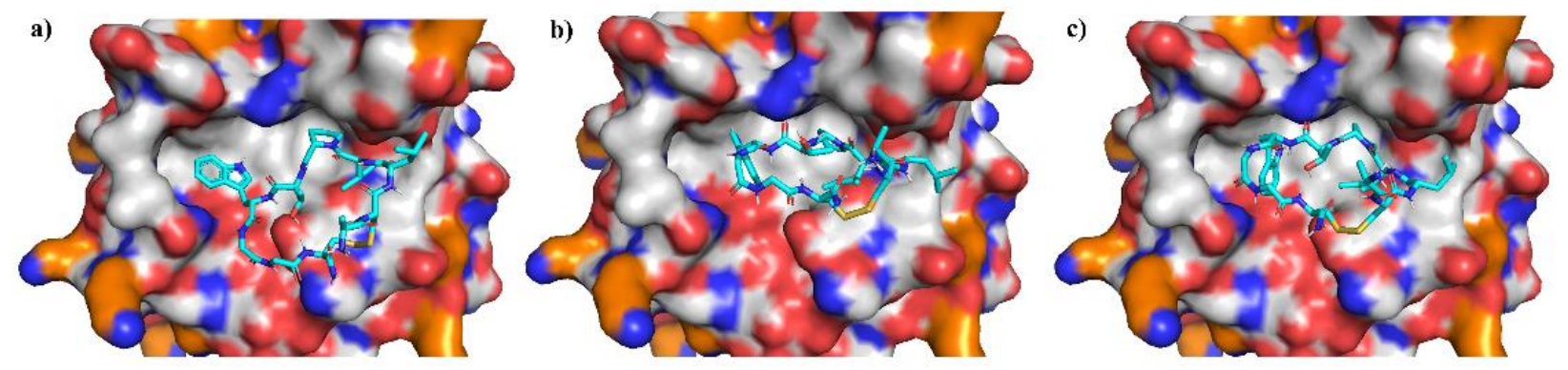

Figure S22: High-scoring conformers in which Trp and Pro residues are bound into the active site of Sortase A.

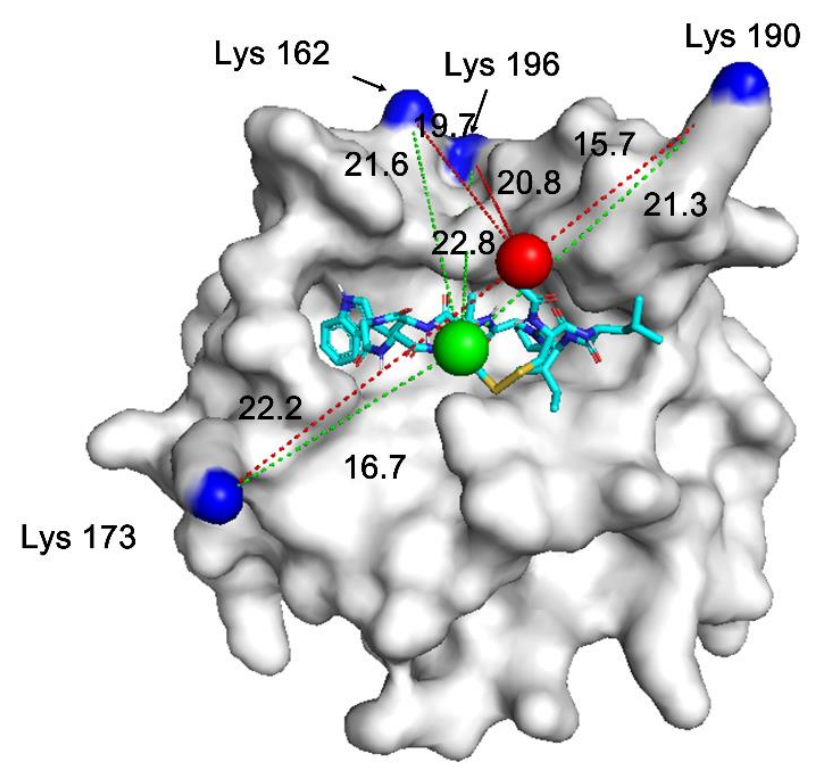

Figure S23: Measured distances between the N-/C- terminus of the docked W7 peptide and the lysine residues in close proximity of the enzyme's binding site. The $\mathrm{N}$ - and C-terminus are highlighted as red and green sphere respectively. The lysine side chain amines are colored blue. 


\section{Procedure for IC $\mathrm{I}_{50}$ Value Determination of Peptides W7, W7-Linear and P1-P8}

Competition assay was performed by measuring fluorescence polarization using reporter peptide W7-F. Briefly, fluorescent labeled peptide W7-F and Sortase A were added to different concentration of inhibitor peptides (P1-P8, W7) such a way that the final conc. of the fluorescent reporter peptide and Sortase A are $200 \mathrm{nM}$ and $3 \mu \mathrm{M}$ respectively. Then it was incubated for about 30 mins (for peptide W7, W7-Linear, P1-P4, P6-P7) or 5h (for peptides P5 and P8). After that, it was transferred to a Costar blk/clrbtm 96 well plate and fluorescence polarization was recorded using emission at $535 \mathrm{~nm}$. upon excitation at $485 \mathrm{~nm}$. The obtained fluorescence polarization value was then plotted against log scale of conc. of inhibitor peptide. The curve was fitted using the following equation and the $\mathrm{IC}_{50}$ values are extracted from it. The experiments were carried out in triplicate and plotted as an average of three trials with standard deviations.
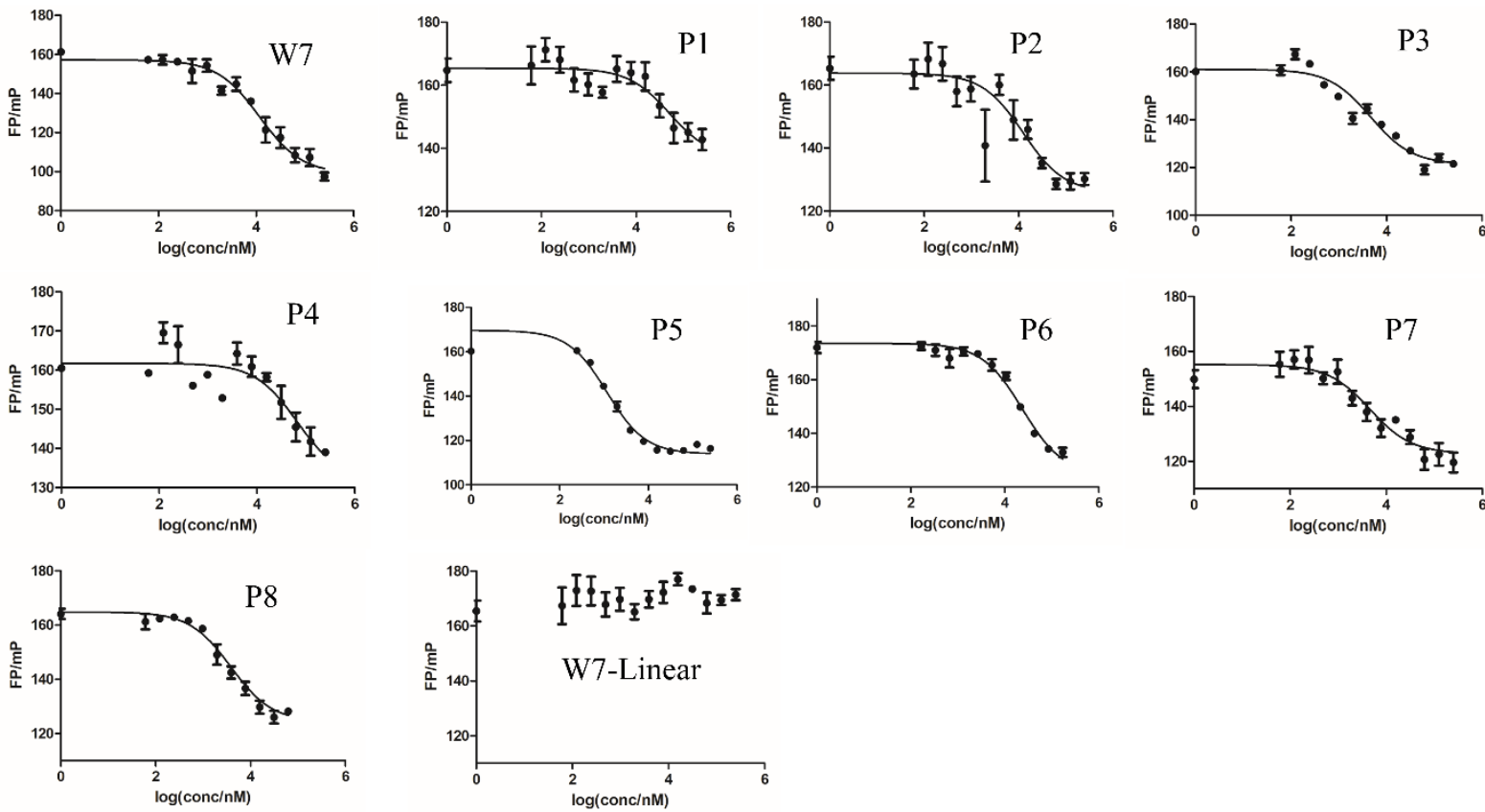

Figure S24: Titration curves obtained from the competition assay of W7, W7-Linear and P1-P8. $\mathrm{IC}_{50}$ values are given as Figure $4 \mathrm{c}$ in the main text. 
a)

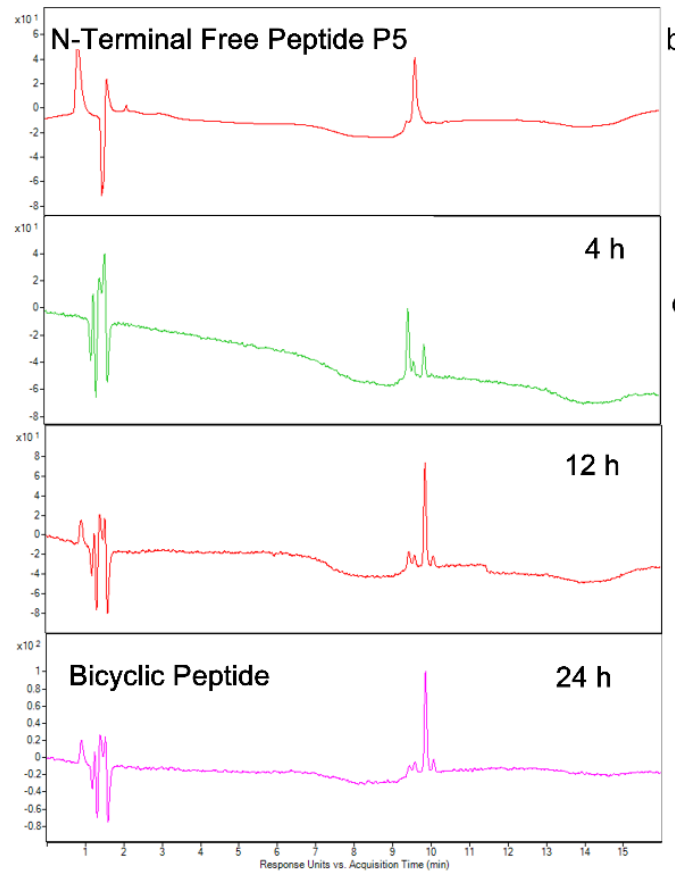

b)

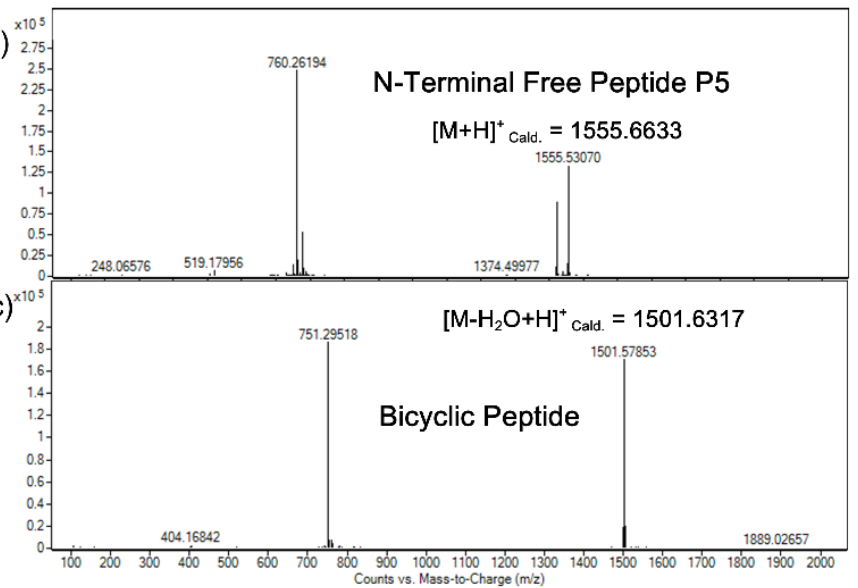

d)

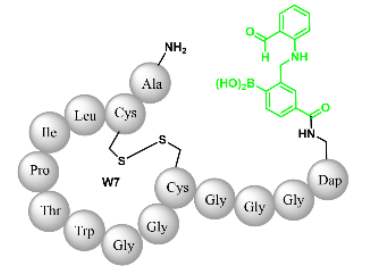

N-Terminal Free Peptide P5

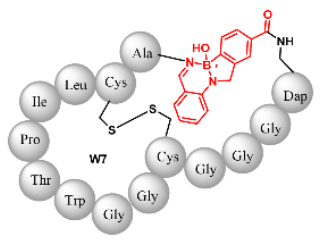

Bicyclic Peptide

Figure S25: Bicyclic peptide formation by reaction between $\mathrm{N}$-terminal $\mathrm{NH}_{2}$ and RMR1 warhead from N-terminal free P5. (a) LC trace of bicyclization over the time in 1x PBS (pH7.4). (b) and (c) ESI-MS spectra of mono and bicyclic peptide. (d) Cartoon representation of N-terminal free P5 and diazaborine bicyclized peptide form P5.
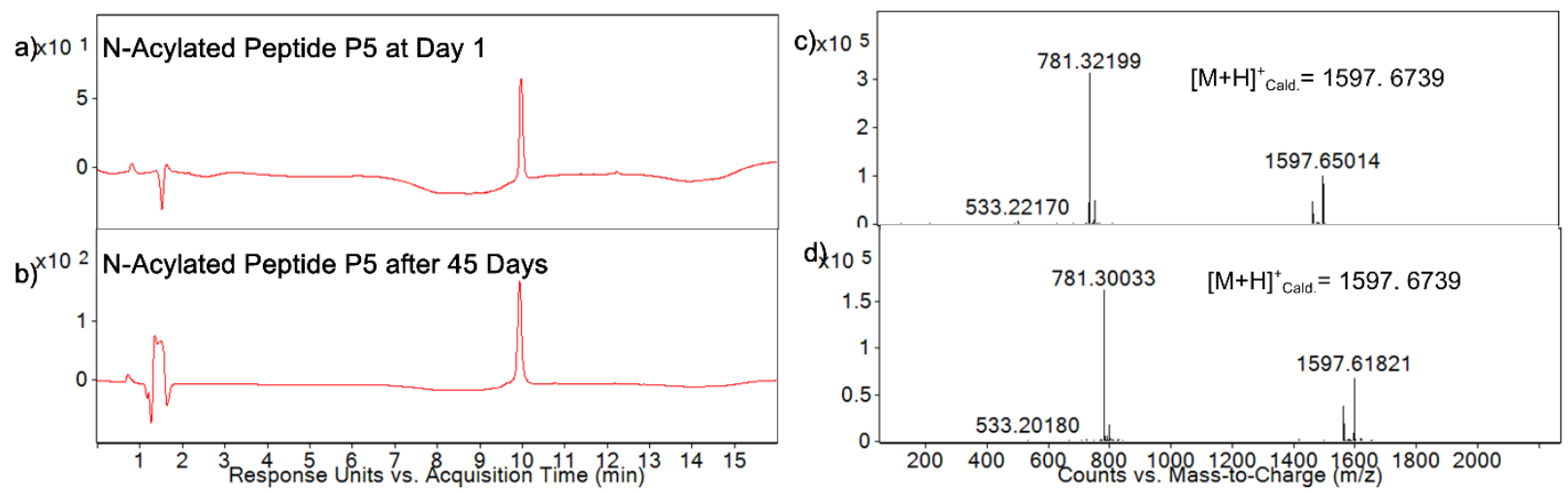

Figure S26: Stability of N-acylated peptide P5 over time in 1× PBS (pH7.4). (a) and (b) LC trace of N-acylated peptide P5 at day 1 and after 45 days respectively. (c) and (d) ESI-MS spectra of $\mathrm{N}$-acylated peptide $\mathrm{P} 5$ at day 1 and after 45 days respectively. 
a)

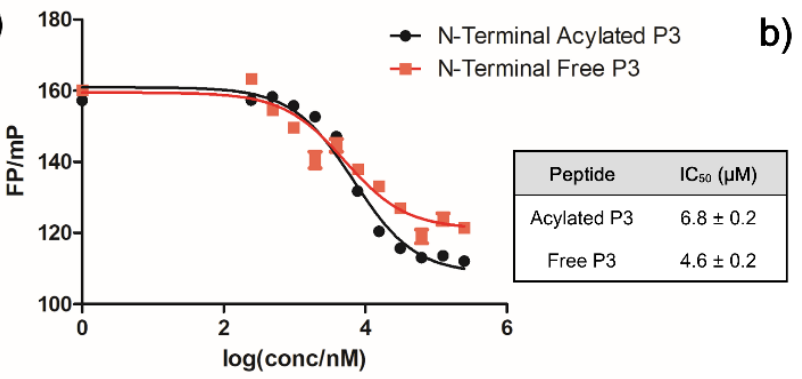

b)

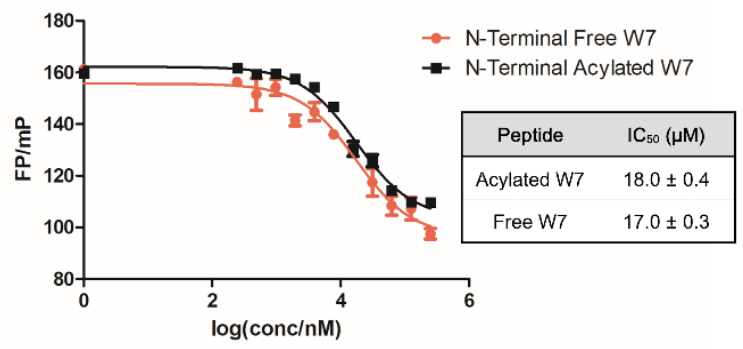

Figure S27: Titration curves obtained from the competition assay of inhibitor peptides of free and $\mathrm{N}$-terminal acetylated peptide of $\mathrm{W} 7$ and $\mathrm{P} 3$ ( $\mathrm{IC}_{50}$ values are given in the insert table).

\section{Procedure for Determination of Kinetic Parameters between Peptide P3 and P5 with Sortase A:}

The association and dissociation kinetics on Sortase $A$ were determined by the fluorescence polarization experiment using a reporter peptide W7-F. The fluorescence polarization data were obtained by measuring emission at $535 \mathrm{~nm}$ upon excitation at $485 \mathrm{~nm}$. For the association experiments, first reporter peptide W7-F at final conc. of $200 \mathrm{nM}$ was incubated with $3 \mu \mathrm{M}$ of Sortase A for $30 \mathrm{~min}$. Then to this solution, $20 \mu \mathrm{M}$ of peptide P3 or P5 (from a stock solution of 5 $\mathrm{mM}$ ) were added and fluorescence polarization was recorded with time. Exemplary kinetic traces are shown in Figure 4e, f. As the reporter peptide was used at much lower concentrations in comparison to the enzyme and the peptide inhibitors, the $I_{50}$ value from the competition experiments can be considered as $K_{d}$ value. Therefore, the kinetic parameters were calculated by fitting the curve using a relaxation kinetics equations (i)-(iii) mentioned earlier (section 7). 


\section{Procedure for Trypsin Digestion of Wildtype Sortase A and Sortase A-P5 Conjugates}

First, Sortase A and peptide P5 at a conc of $75 \mu \mathrm{M}$ were incubated for overnight to form Sortase A-P5 conjugate. The formation of the conjugate was confirmed by LC-MS analysis. The results indicate that $\sim 85 \%$ of conjugates were formed (Figure S28). After that, the conjugates were denatured in $6 \mathrm{M}$ urea at $37^{\circ} \mathrm{C}$ for $30 \mathrm{~min}$. Then the free Cys of denatured SortaseA-P5 conjugates were alkylated by treating iodoacetamide for $30 \mathrm{~min}$ at rt. Then the alkylated SortaseA-P5 digested by treating with Trypsin Gold (Mass Spectrometry Grade, from Promega) at a ratio of 1:25 (enzyme: substrate) ratio for $2 \mathrm{~h}$ at $37^{\circ} \mathrm{C}$. After $2 \mathrm{~h}$, the digestion reaction was quenched with formic acid ( $\sim 5 \%$ of the final volume). The undigested pellets were removed by centrifuge and 10 $\mu \mathrm{L}$ of supernatant was directed injected into LC-MS. The modification site of the fragment was monitored by UV absorbance trace @ 425nm (the diazaborine absorbs at $425 \mathrm{~nm}$ ). For control experiment, sortase A alone was digested with trypsin under the same conditions and then subjected to LC-MS analysis.

a)

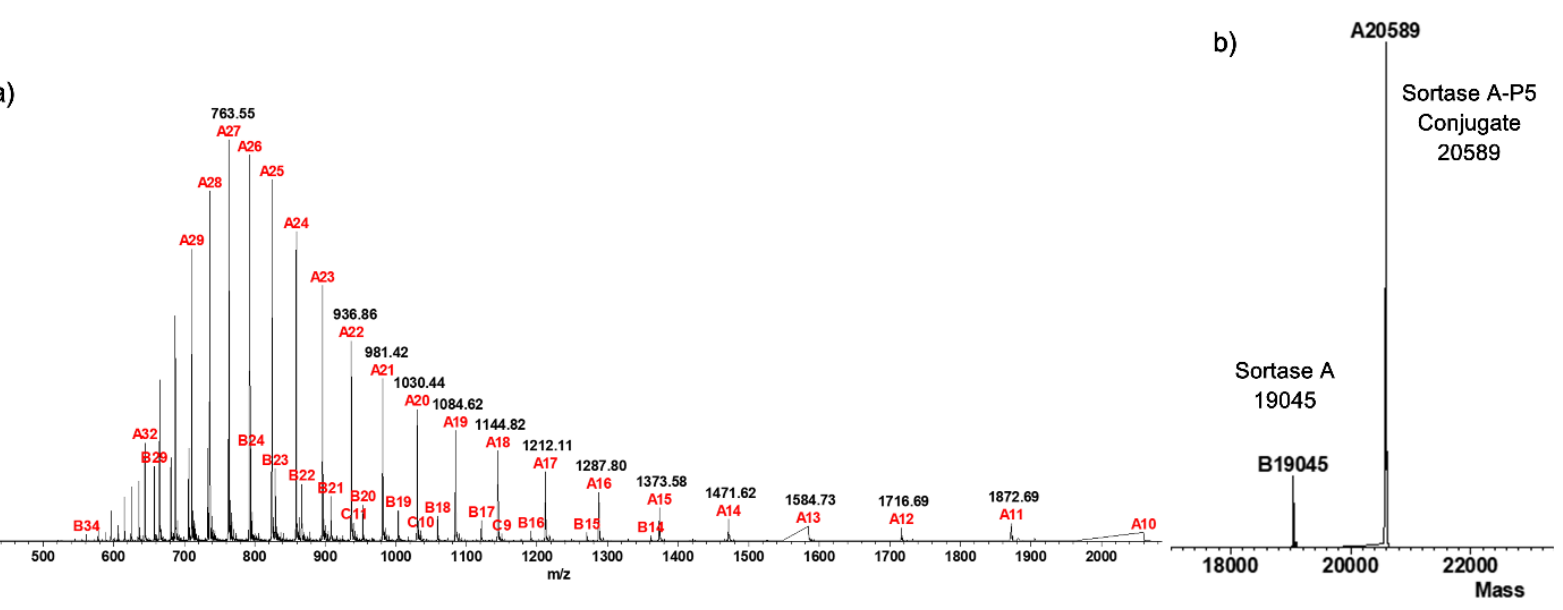

Figure S28: Covalent adduct of sortase A and P5. (a) and (b) are crude and deconvoluted massspec data demonstrating sortase-P5 conjugation formation. 
a)

b)
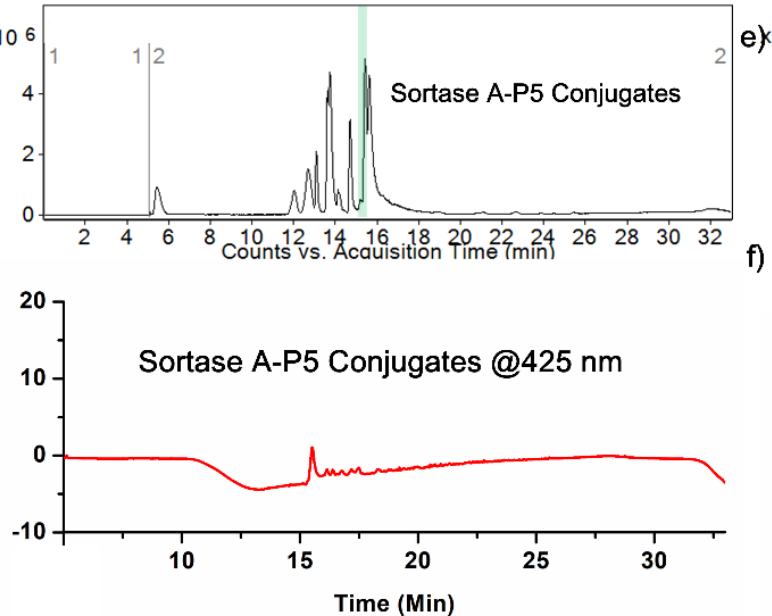

c)

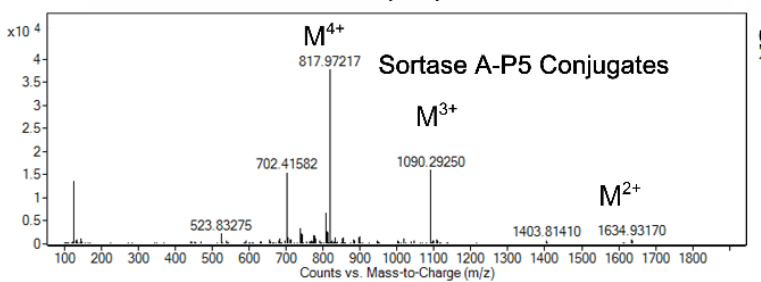

d)

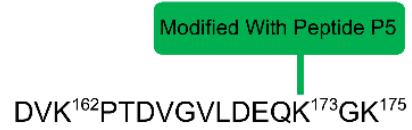

Expected Mass. 3270

Observed Mass. $\mathrm{M}^{2+} 1634$

$\mathrm{M}^{3+} 1090$

$\mathrm{M}^{4+} 817$
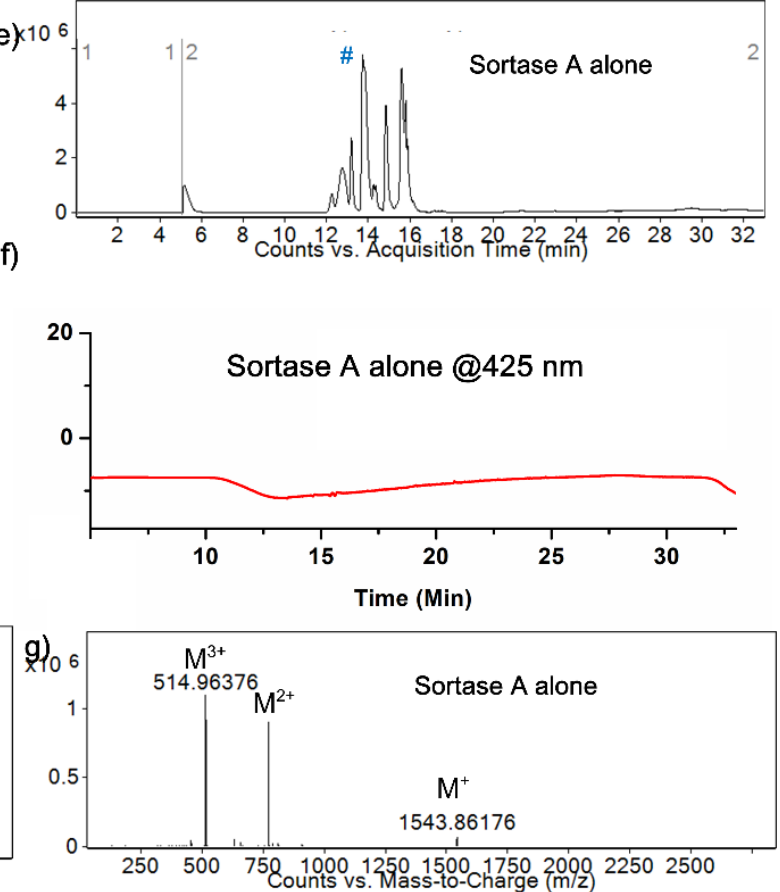

h)

DVK $^{162}$ PTDVGVLDEQK ${ }^{173}$

Expected Mass. 1542

Observed Mass. $\mathrm{M}^{+} 1543$

$\mathrm{M}^{2+} 771$

$\mathrm{M}^{3+} 514$

Figure S29: Peptide mapping to identify the conjugation site of P5 on sortase A. Shown for sideby-side comparison are the TIC (Total lon Count) $(a, e)$ and LC $(b, f)$ traces of trypsin digested sortase-P5 conjugate (a,b) and sortase alone (e, f). Comparison of (b) and (f) shows a distinct peak (retention time: $15.5 \mathrm{~min}$ ) with diazaborine absorption in the trypsin digested sortase-P5 mixed sample, which is absent from the trypsin digested sortase alone. Mass-spec data (c) of this distinct peak corresponds to the P5 conjugate of peptide D160-K175 (d). This peptide fragment contains two lysines K162 and K173. (g) shows the mass-spec data of sortase alone, specifically the peak marked with \# in (e), which corresponds to peptide D160-K173 (h), which suggests that trypsin cleaves K173 of sortase, but not K162. Comparing the mass-spec data of sortase alone versus the sortase-P5 conjugate indicates P5 conjugation makes K173 no longer susceptible to trypsin cleavage, hence, we conclude $\mathrm{K} 173$ is the conjugation site of P5 as a reversible covalent inhibitor. 


\section{Procedure for the Inhibition of Sortase A activity on S. aureus by Peptides W7, P3 and P5}

\section{a. Protocol for $I C_{50}$ determination on live cells}

The inhibitory effect of peptides W7, P3 and P5 on sortase activity on S. aureus cells was measured using a fluorescently labeled peptide substrate (FAM-GSLPETGGS). ${ }^{7}$ First $S$. aureus cells (strain ATCC 6538) were cultured in $10 \mathrm{~mL}$ of LB media to reach $O D=0.1$. After that, the peptide substrate $(0.3 \mathrm{mM})$ and an inhibitor peptide at varied concentrations $(0.1 \mu \mathrm{M}$ to $250 \mu \mathrm{M})$ were incubated together with the $S$. aureus cells in LB media for $6 \mathrm{~h}$ at $37^{\circ} \mathrm{C}$. Then the $S$. aureus cells were washed with $500 \mu \mathrm{L}$ of $1 \times$ DPBS under $3700 \mathrm{rpm}, 5 \mathrm{~min}$ for 3 times. Then the fluorescence from the cells was quantified using flow cytometry analysis. Flow cytometry analysis were carried out by diluting cells to $10^{6} \mathrm{cfu} / \mathrm{mL}$ in $1 \times$ DPBS (Exemplary crude data set shown in Figure S30). The median florescence intensity of FITC channel was normalized against that of positive control (no inhibitor), and then plotted against conc. of the inhibitor peptide (Figure 5c). The curves were fitted by the following the equation below to get the $\mathrm{IC}_{50}$ value. The flow cytometry measurements were carried out in triplicates and each data points in Figure $5 \mathrm{c}$ were plotted as an average of the triplicate samples.

$$
\mathrm{Y}=\text { Bottom }+(\text { Top }- \text { Bottom }) /\left(1+10^{\wedge}\left(\mathrm{X}-\text { Log } \mathrm{CC}_{50}\right)\right)
$$

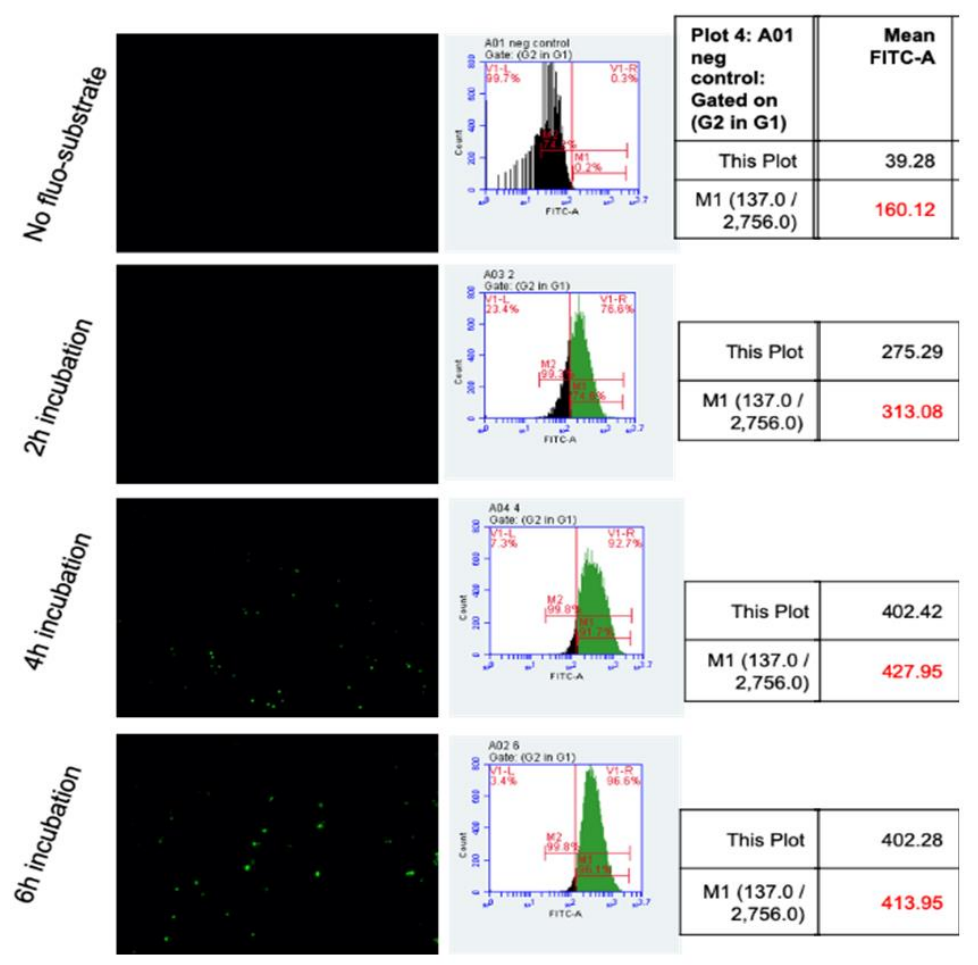

Figure S30: Flow cytometry analysis of Sortase A mediated fluorescence labeling of $S$. aureus. 

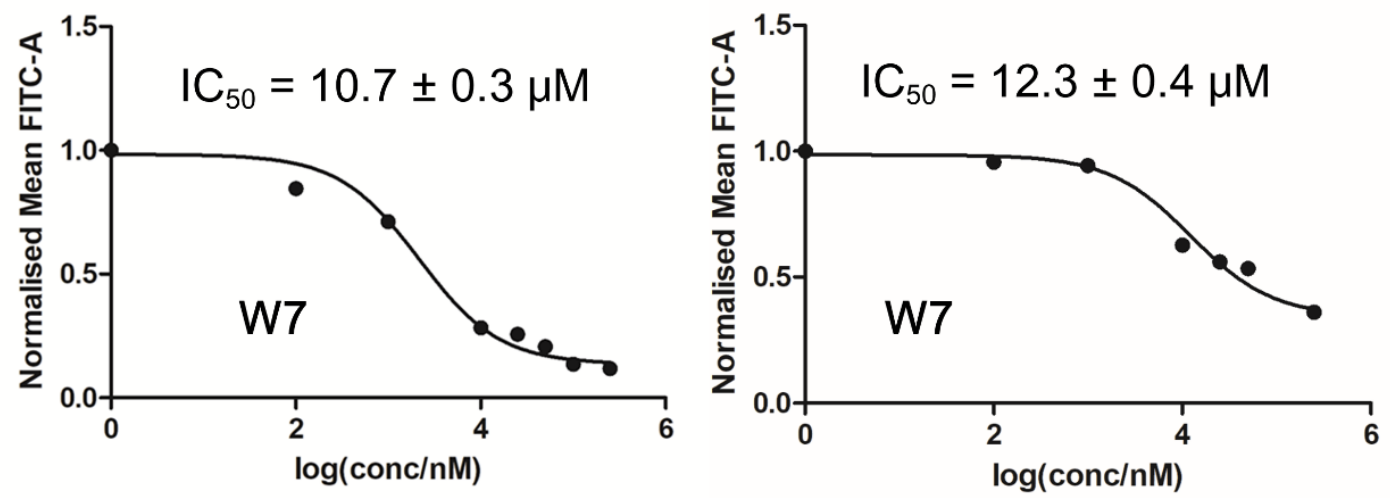

Figure S31: Sortase inhibition of W7 on live S. aureus cells. The replicate experiments carried out on different days gave consistent results.

\section{b. Long Acting Inhibition from Peptide P5 on S. aureus:}

$S$. aureus (strain ATCC 6538) was cultured in $10 \mathrm{ml}$ LB to reach $\mathrm{OD}=0.1$. Inhibitor peptides (W7, P3, and P5) at a conc. of $20 \mu \mathrm{M}$ were incubated with the $S$. aureus culture with total volume $1 \mathrm{~mL}$ for $4 \mathrm{~h}$ at room temperature. After that, $S$. aureus cells were thoroughly washed with $500 \mu \mathrm{L} 1 \times$ DPBS under $3700 \mathrm{rpm}, 5 \mathrm{~min}$ for 3 times to remove the non-covalently bound peptides. Then the cells were aging incubated with fluorescently labeled peptide substrate $(0.3 \mathrm{mM})$ in $\mathrm{M} 9$ media for another $6 \mathrm{~h}$ at room temperature. After that, the cells were washed with $500 \mu \mathrm{L} 1 \times$ DPBS under $3700 \mathrm{rpm}, 5 \mathrm{~min}$ for 3 times. Then the fluorescence from the cells was quantified using flow cytometry analysis. Flow cytometry analysis was carried out by diluting cells to $10^{6} \mathrm{cfu} / \mathrm{ml}$ in $1 \times$ DPBS. The median florescence intensity of FITC channel was normalized against positive control and plotted. All experiments were carried out in triplicates and plotted as an average of three trials with standard deviations (Figure 5c).

\section{c. Fluorescence Microscopy Sample Preparation:}

For fluorescence microscopy images, $S$. aureus cells were diluted to OD $=1$ in $1 \times$ DPBS and $4 \mu \mathrm{L}$ of the suspension was then placed on a glass slide. Then white light and fluorescent images were obtained on Zeiss microscope equipped with filter set 44 (excitation: BP 475/40, emission: BP 530/50). The images were captured using the $100 x$ oil immersion with 1000 ms exposure time. All the images were further processed using Image $\mathrm{J}$ software with same parameters. 
18. LC-MS trace and ESI-MS ${ }^{+}$of Purified Peptides
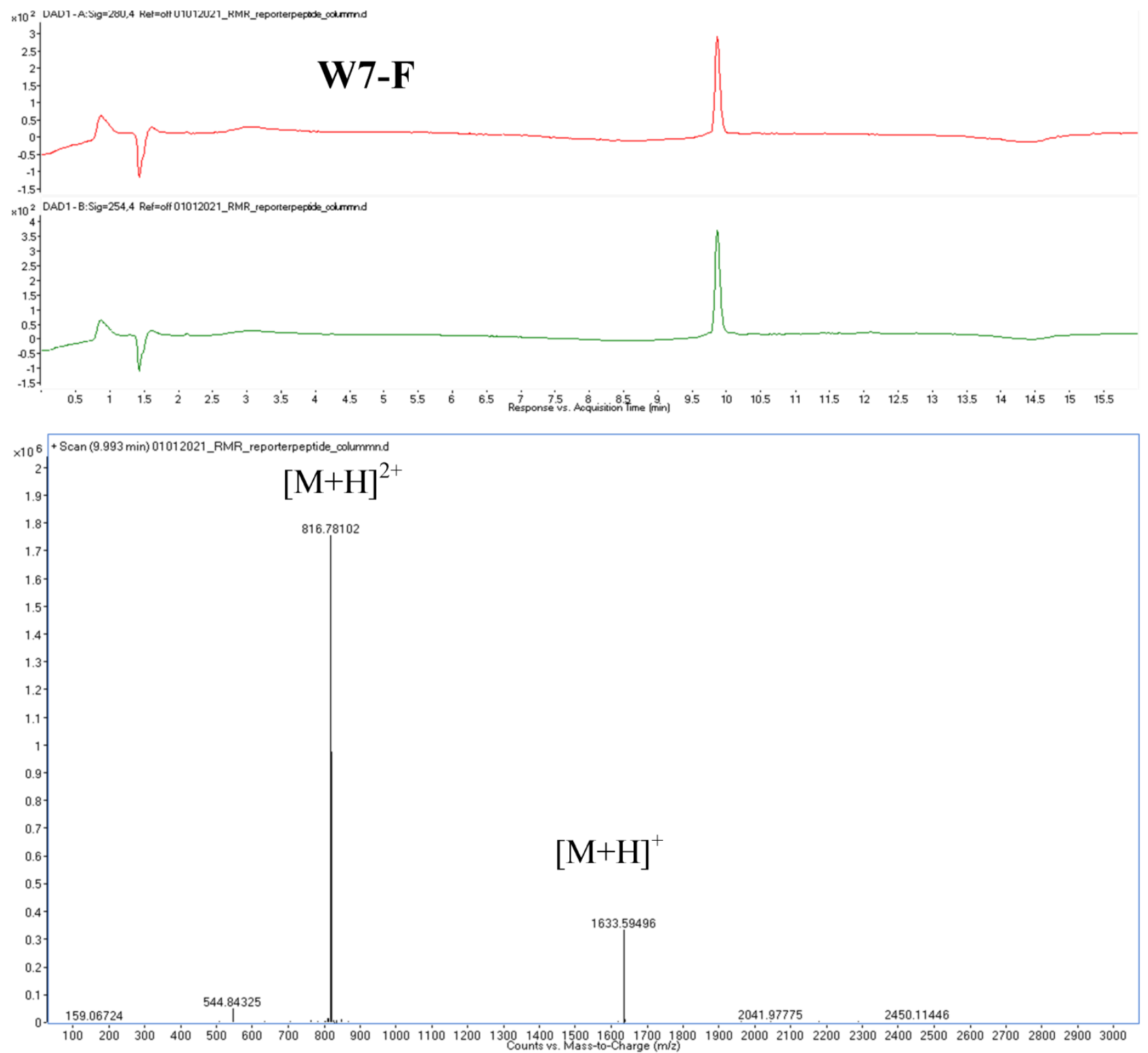

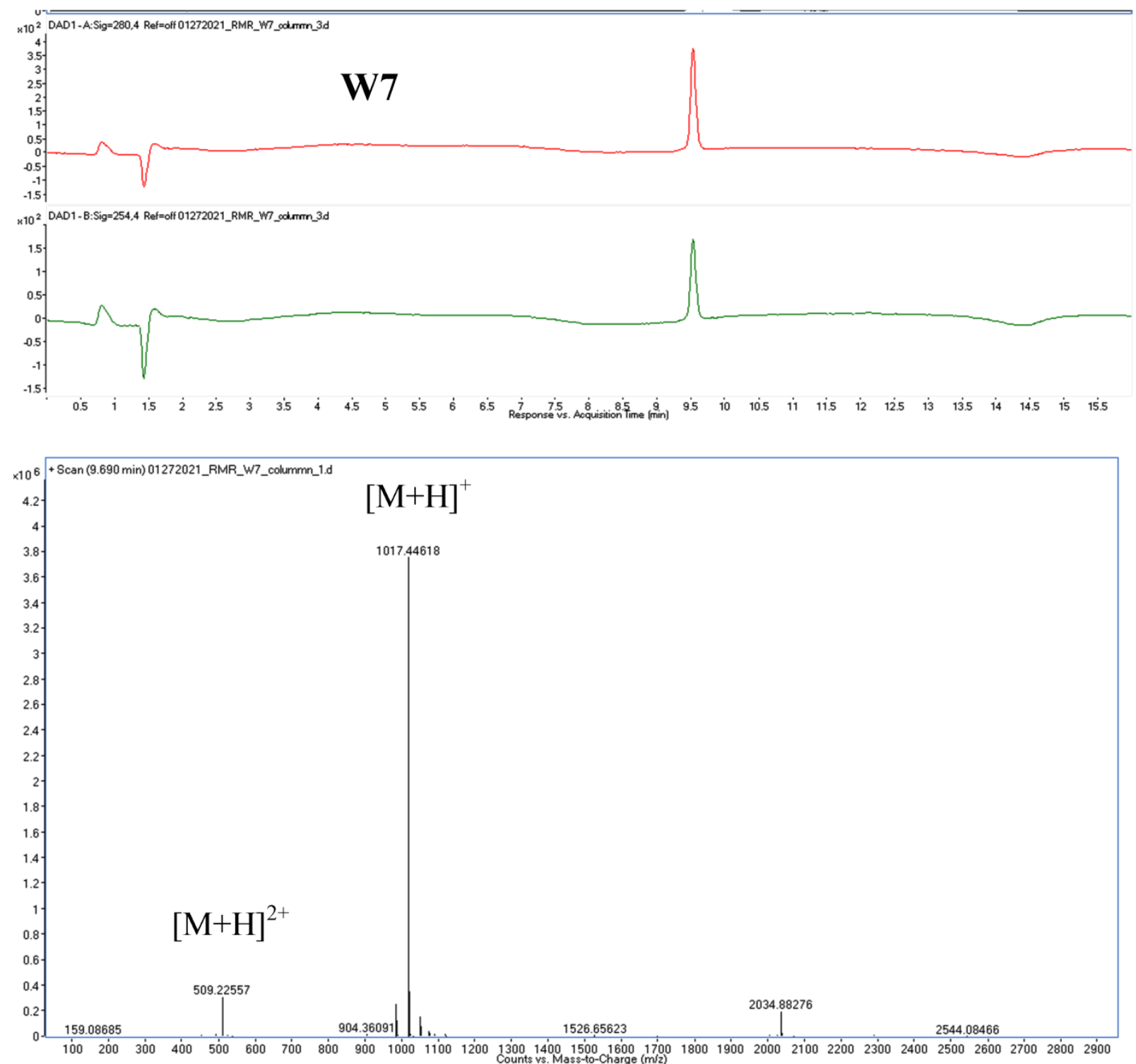


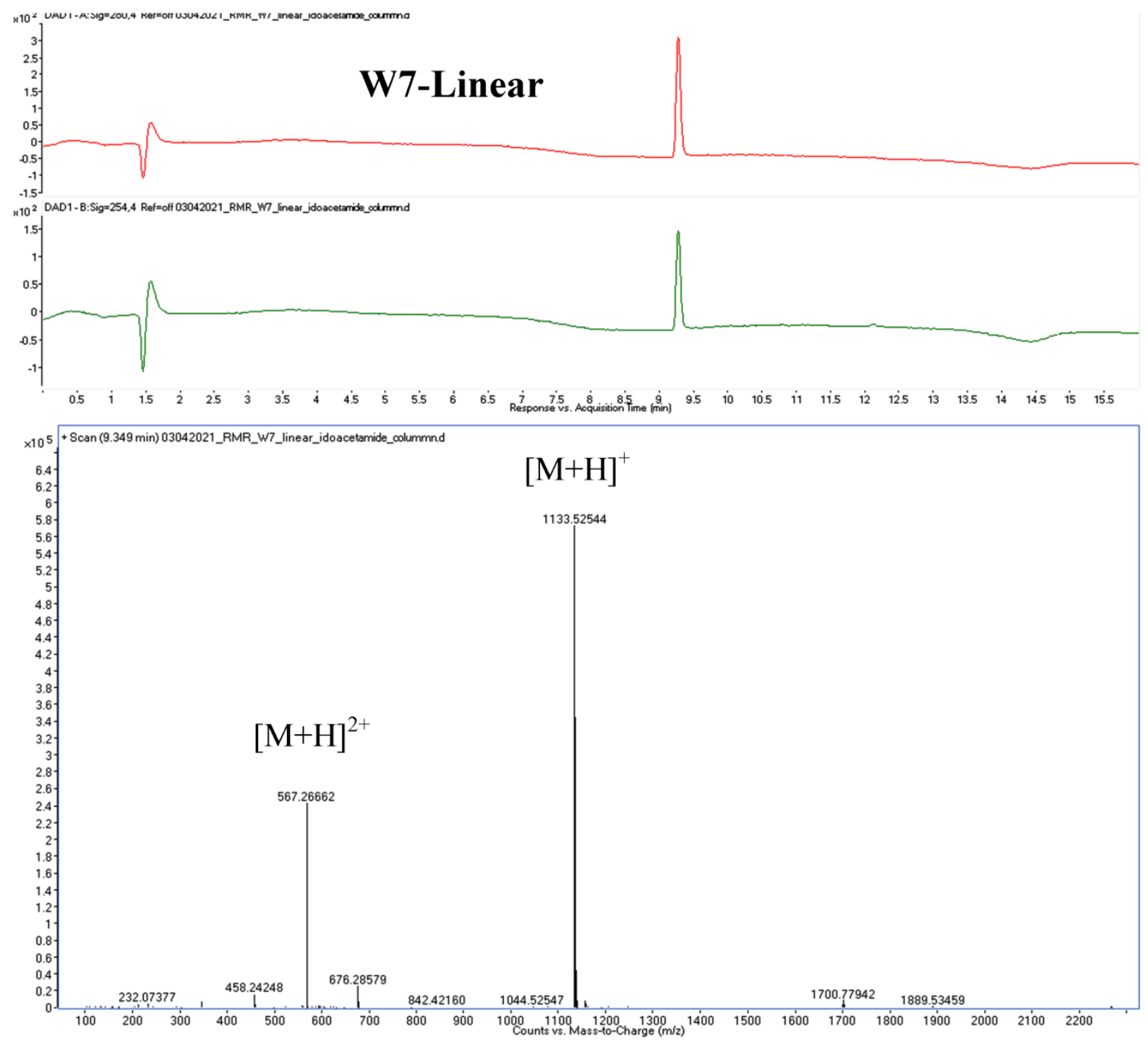



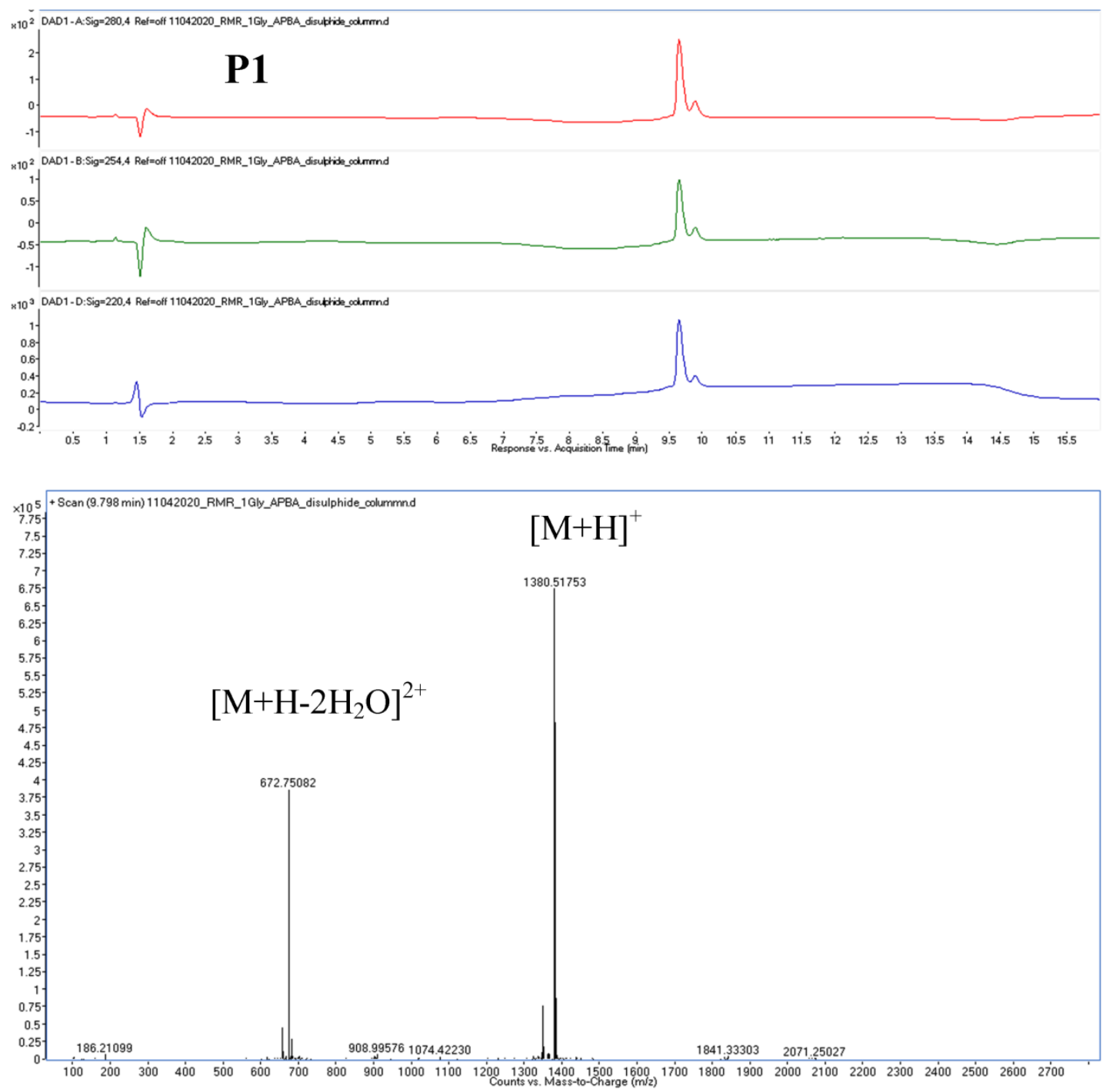

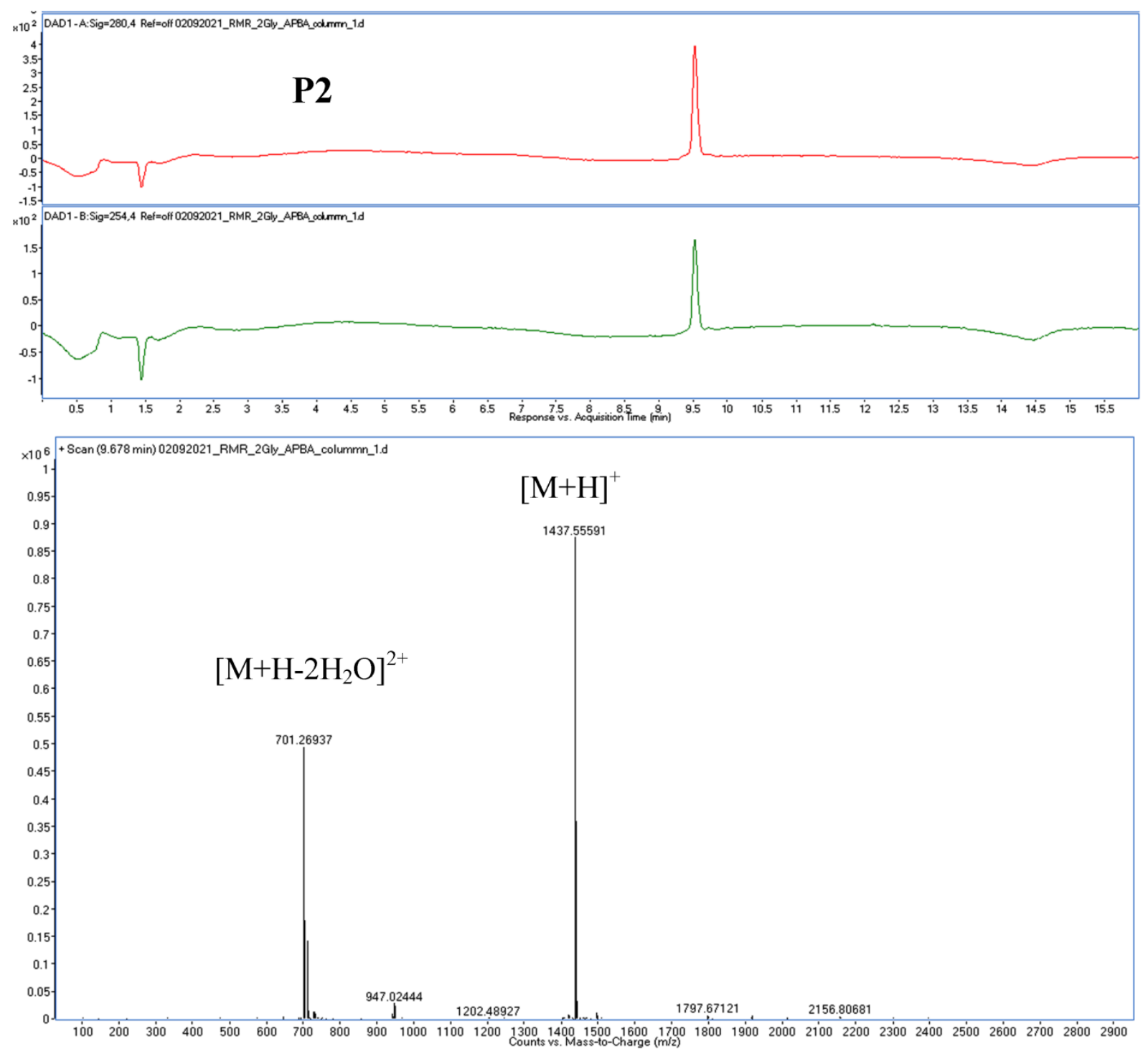

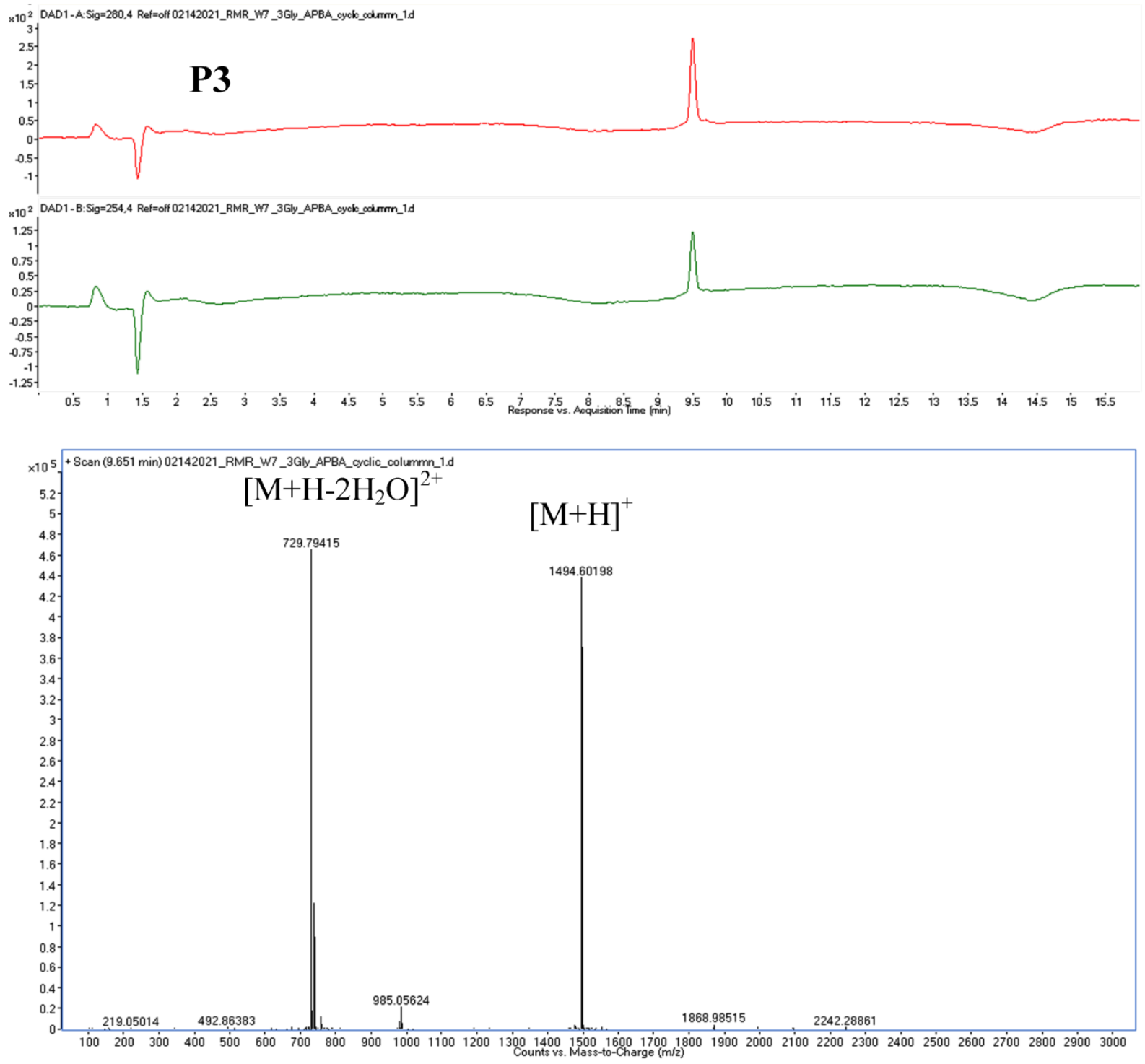


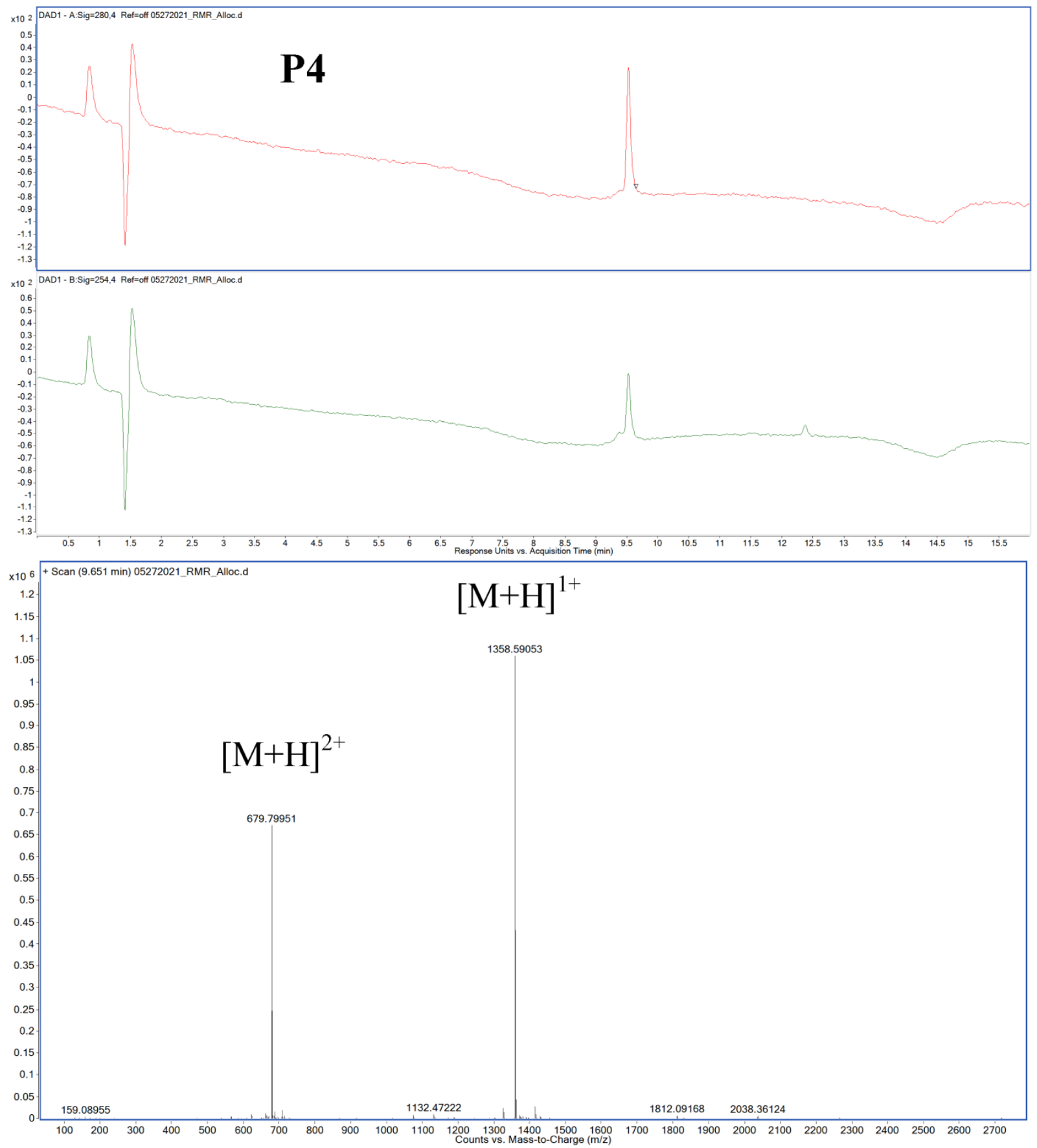




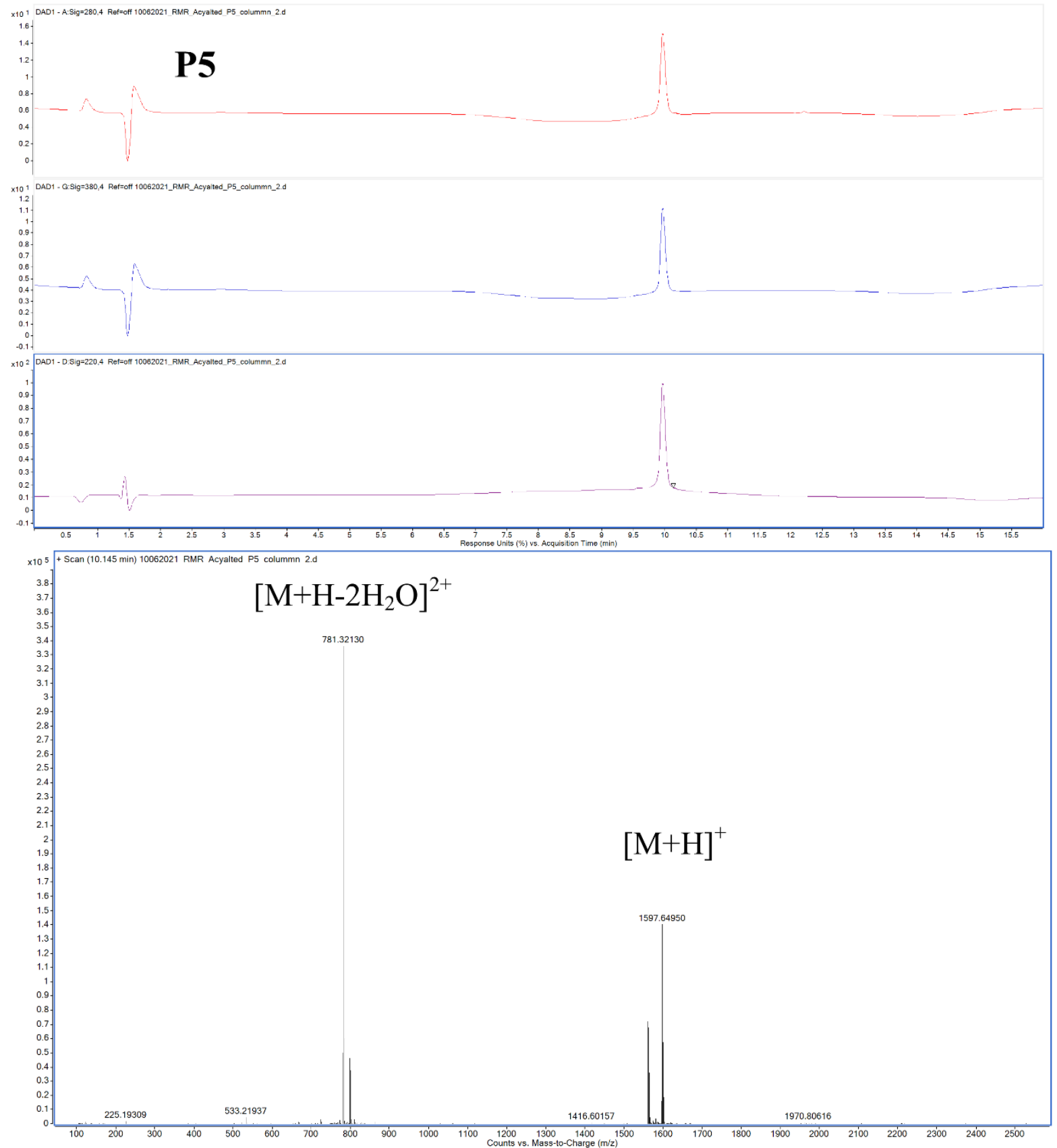



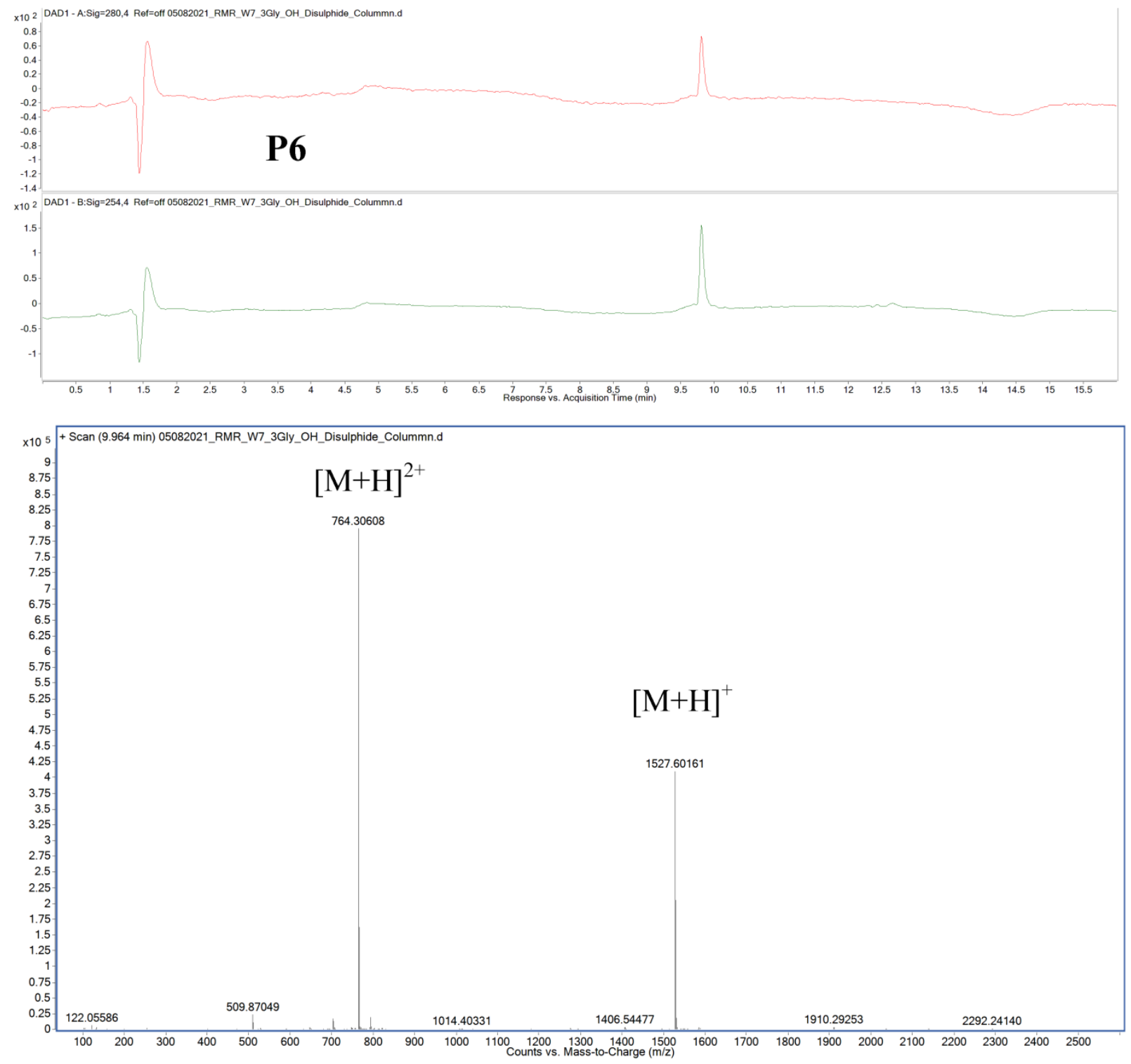

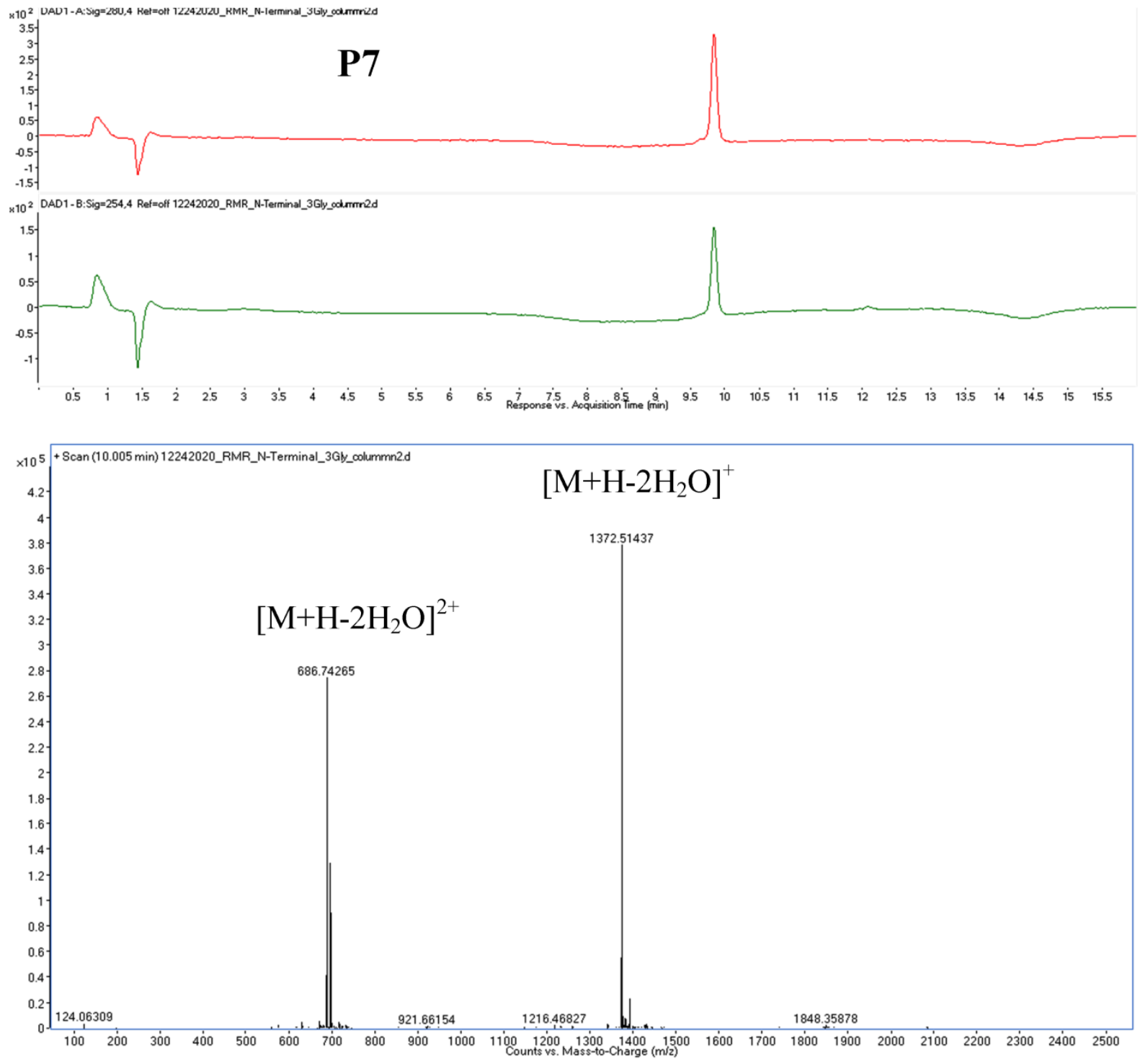

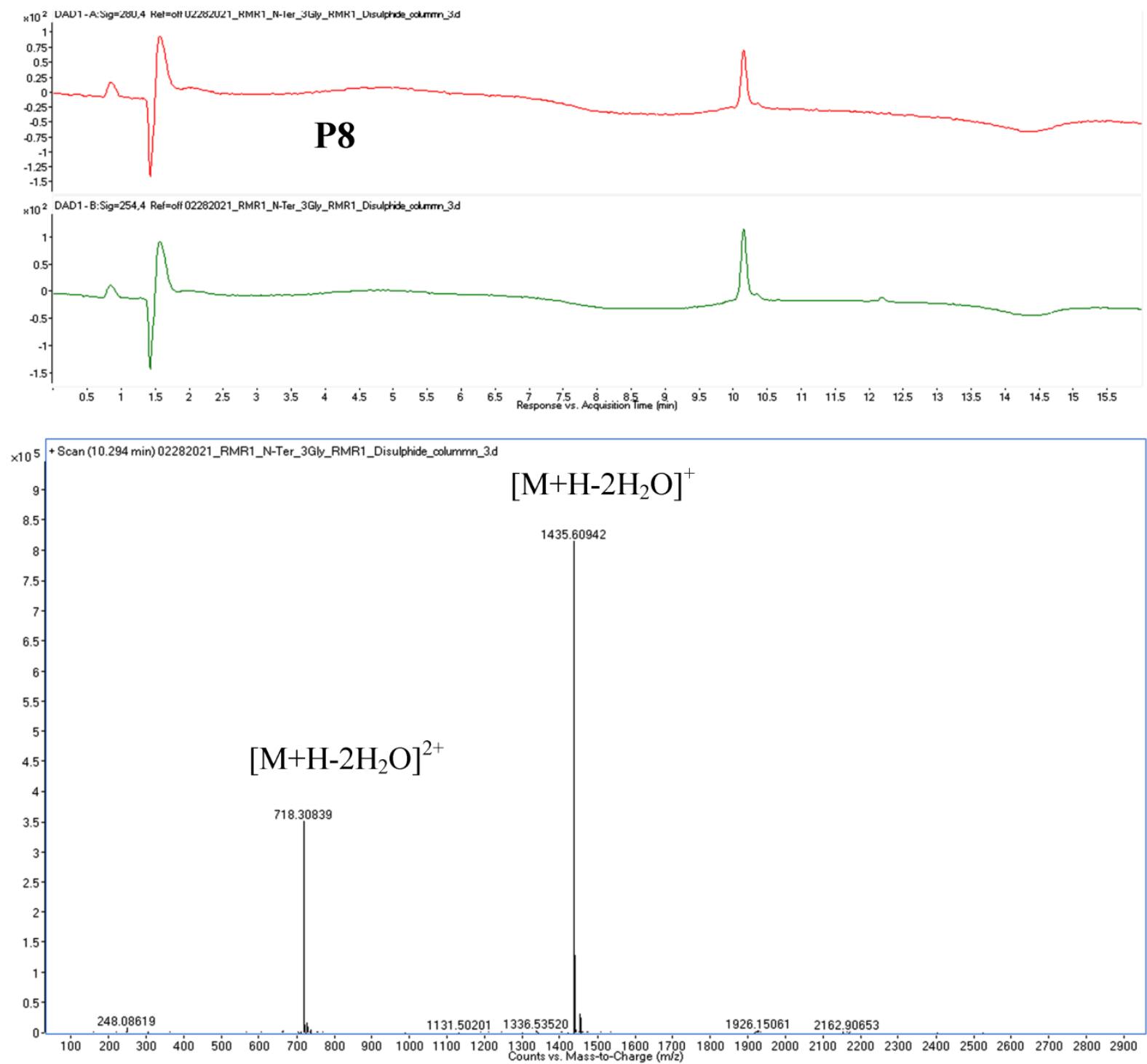

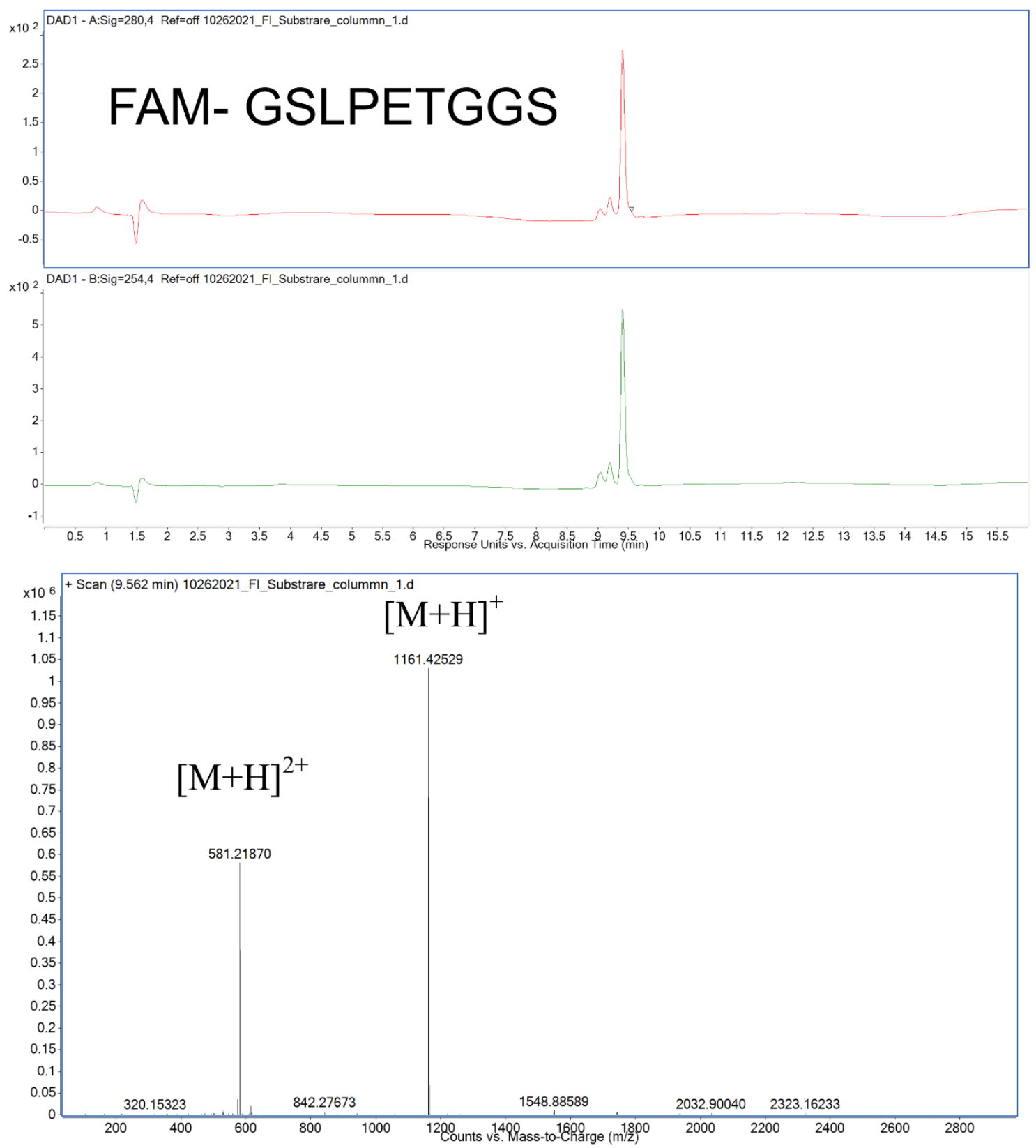
19. ${ }^{1} \mathrm{H}$ NMR and ${ }^{13} \mathrm{C}$ NMR Spectra
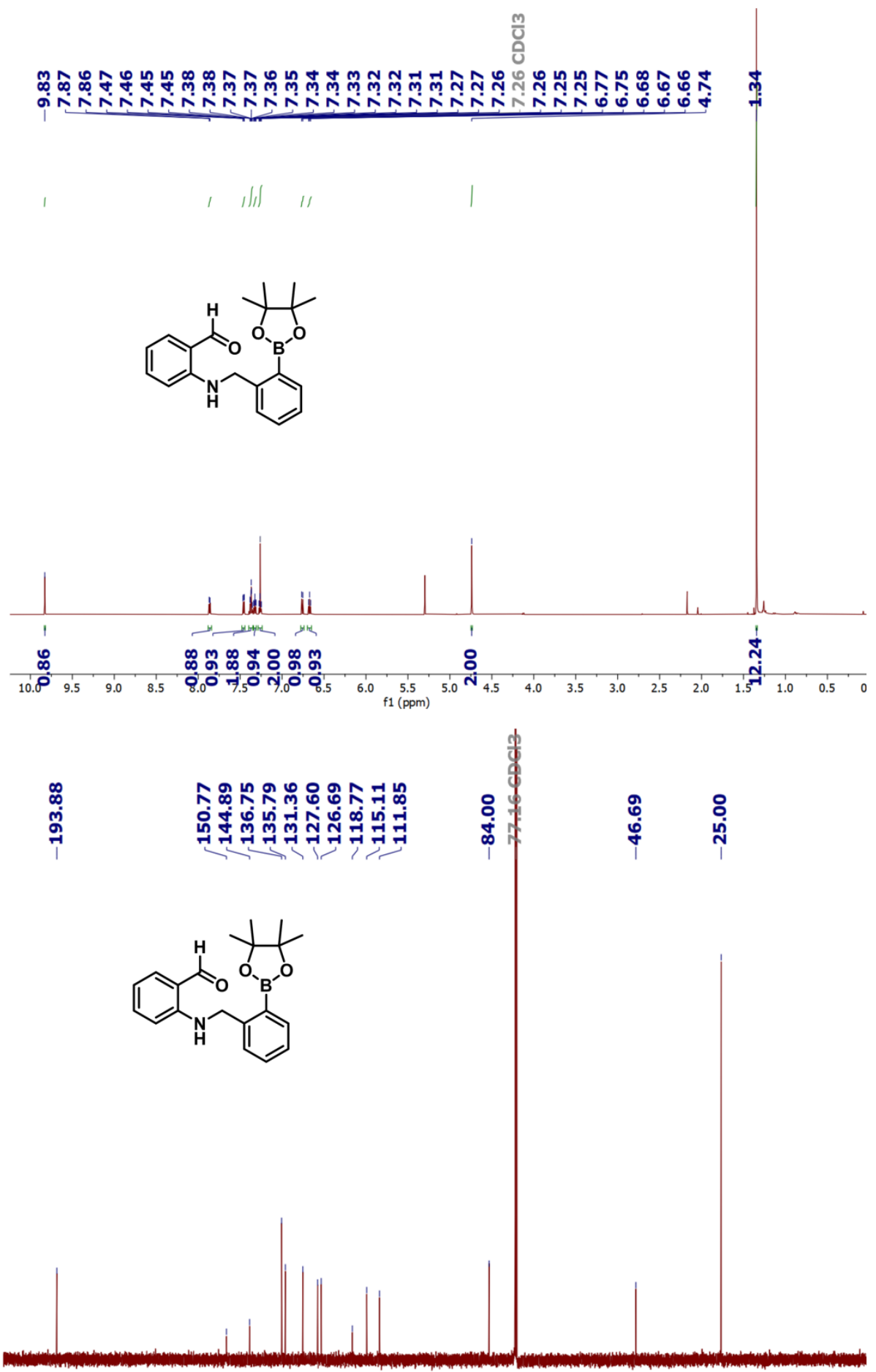

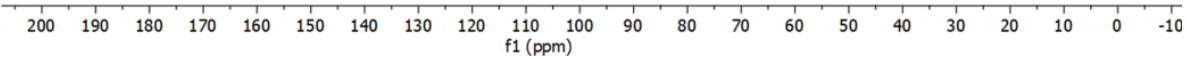




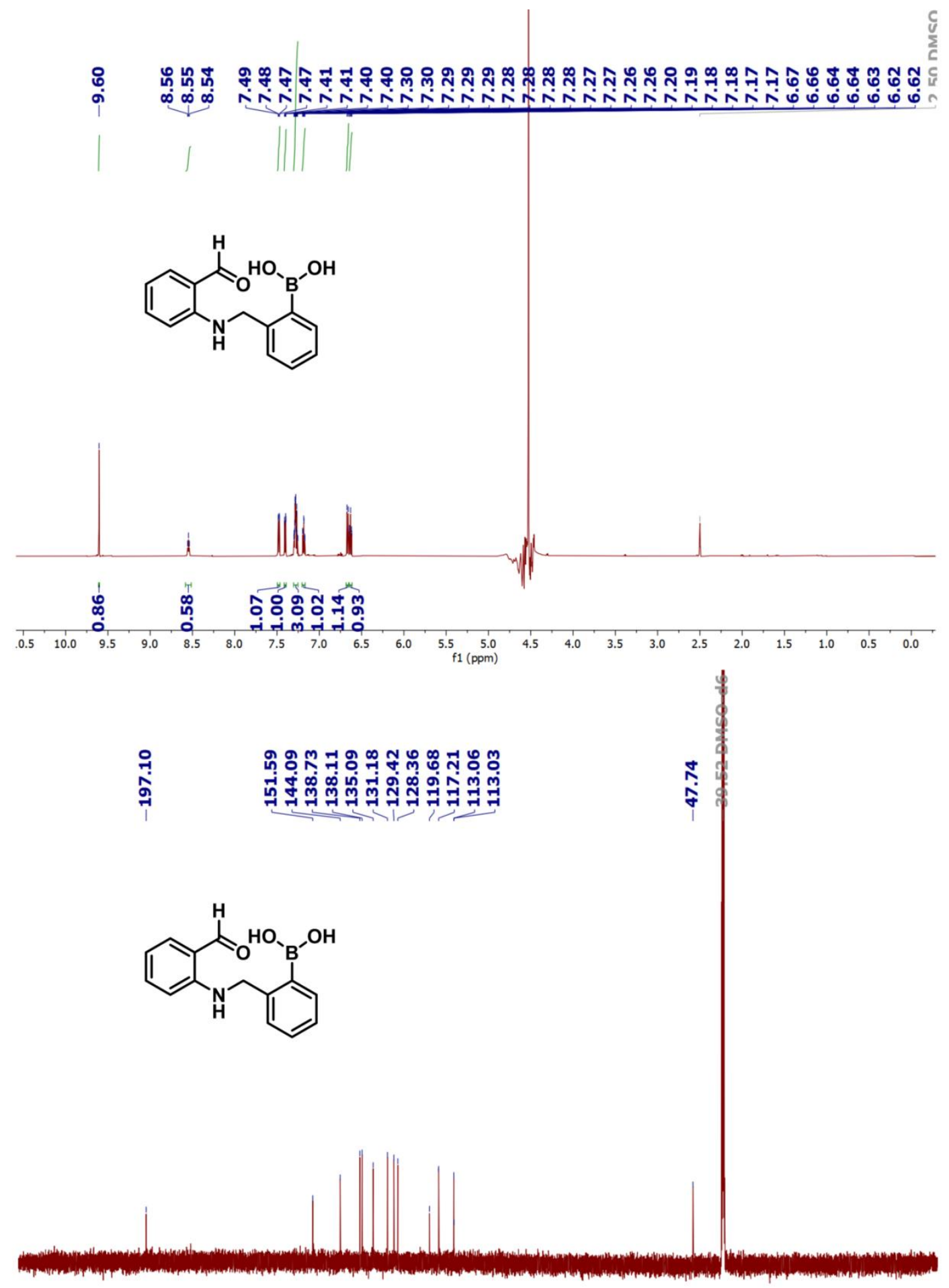

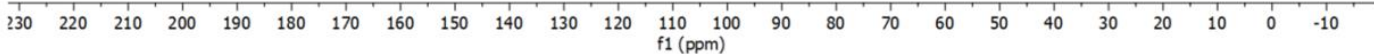




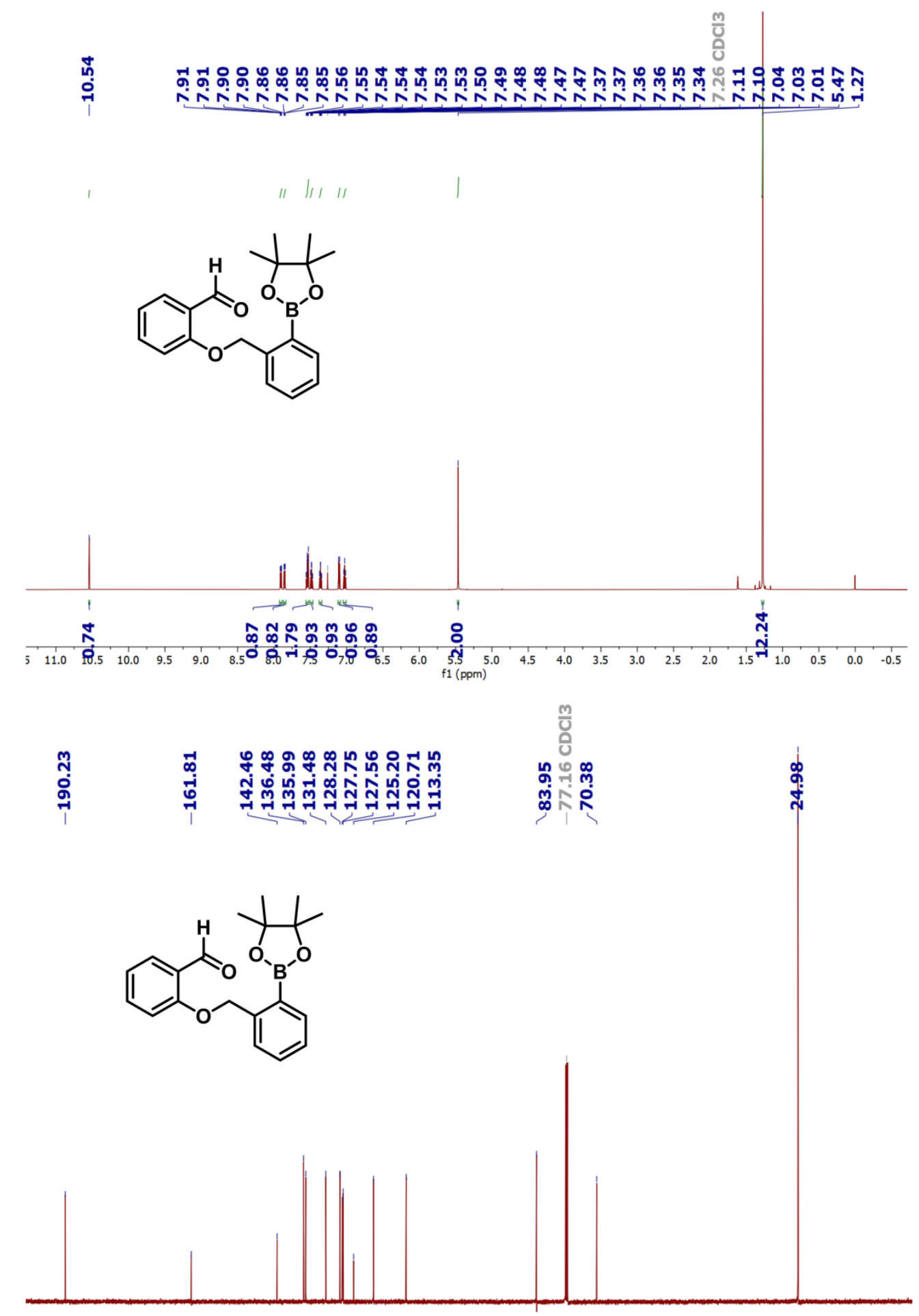

\begin{tabular}{lllllllllllllllllllll}
\hline 0 & 190 & 180 & 170 & 160 & 150 & 140 & 130 & 120 & 110 & 100 & 90 & 80 & 70 & 60 & 50 & 40 & 30 & 20 & 10 & 0
\end{tabular} 


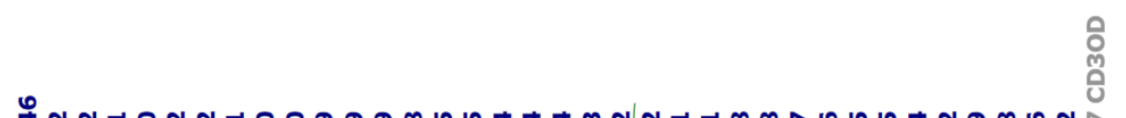

施

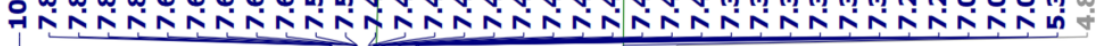<smiles>O=Cc1ccccc1OCc1ccccc1B(O)O</smiles>

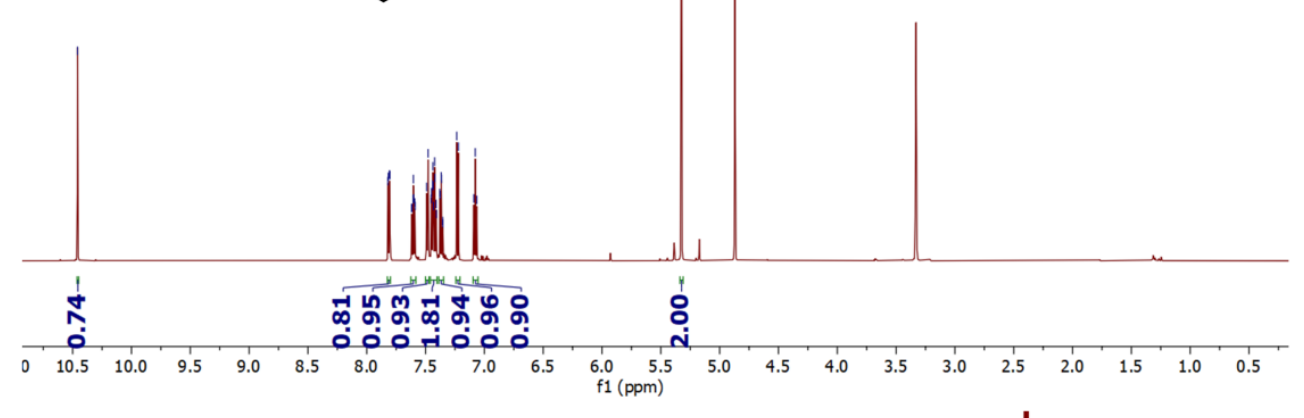

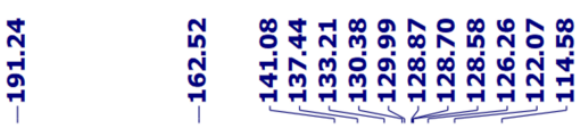

$\stackrel{i}{\text { i }}$<smiles>O=Cc1ccccc1OCc1ccccc1B(O)O</smiles>

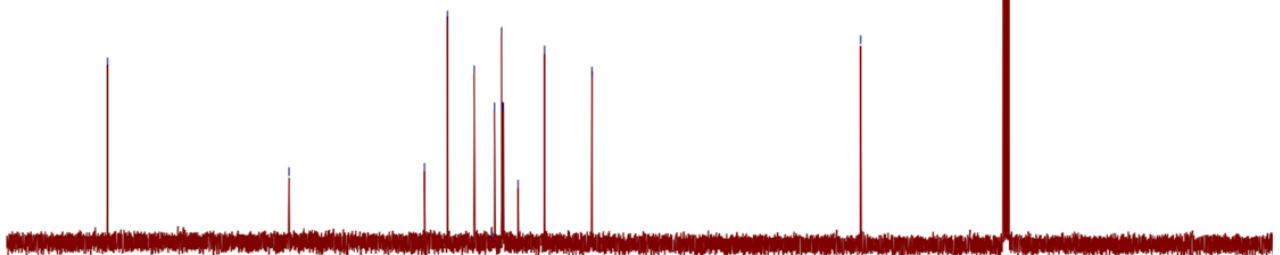

$\begin{array}{llllllllllllllllllllll}1 & 1 & 1 & 1 & 180 & 170 & 160 & 150 & 140 & 130 & 120 & 110 & 100 & 90 & 80 & 70 & 60 & 50 & 40 & 30 & 20 & 10\end{array}$ 


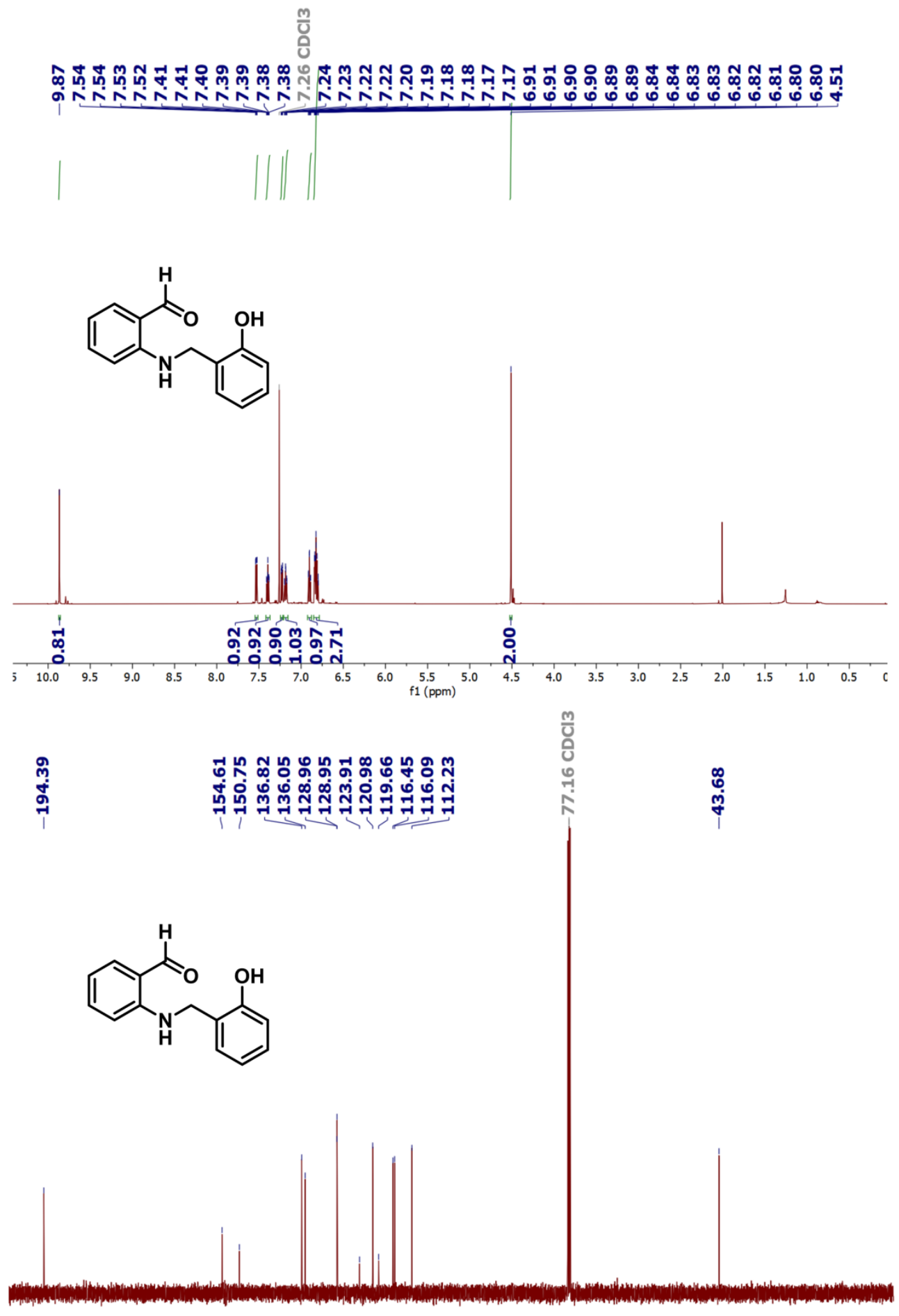

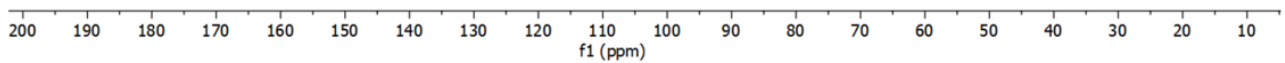




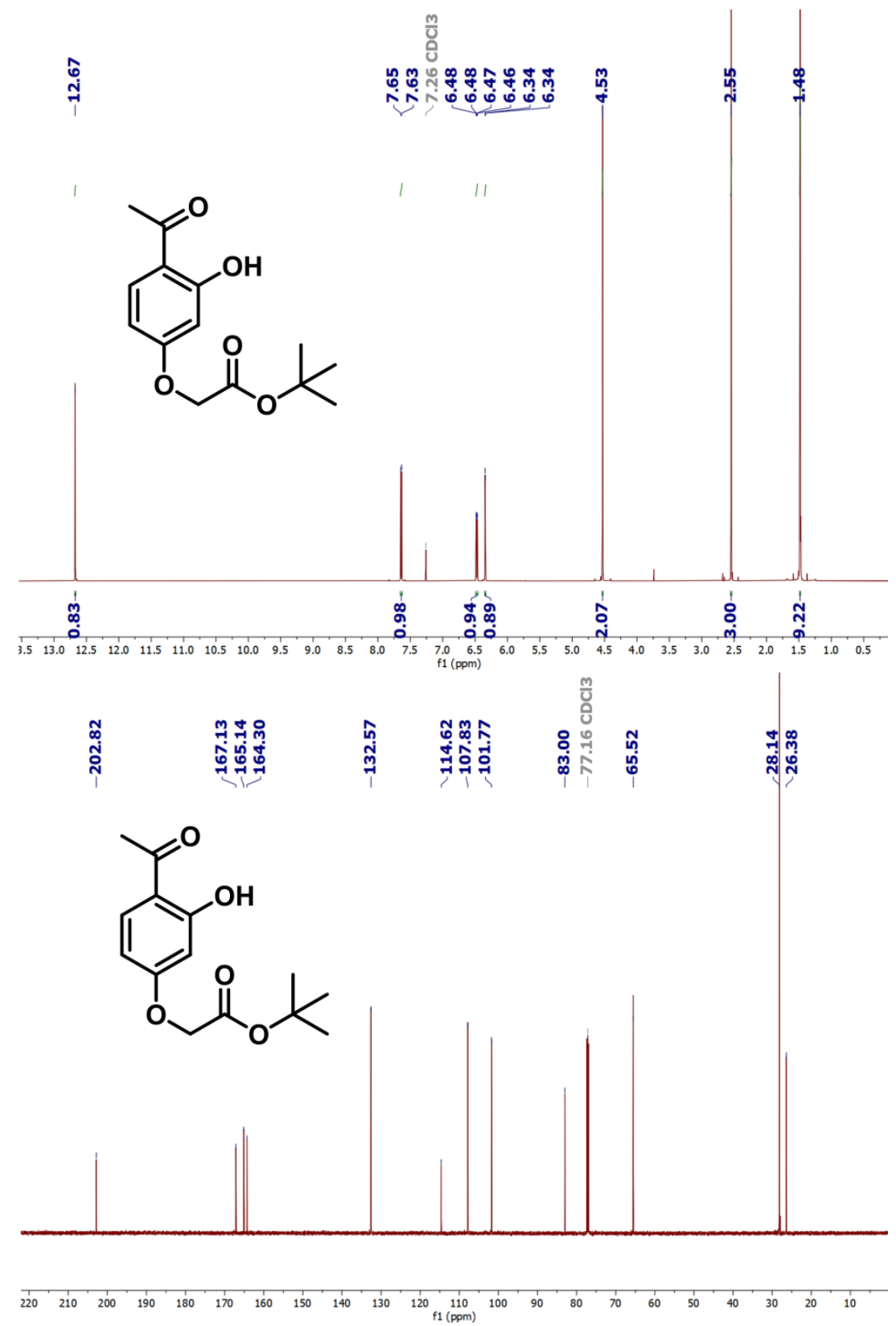




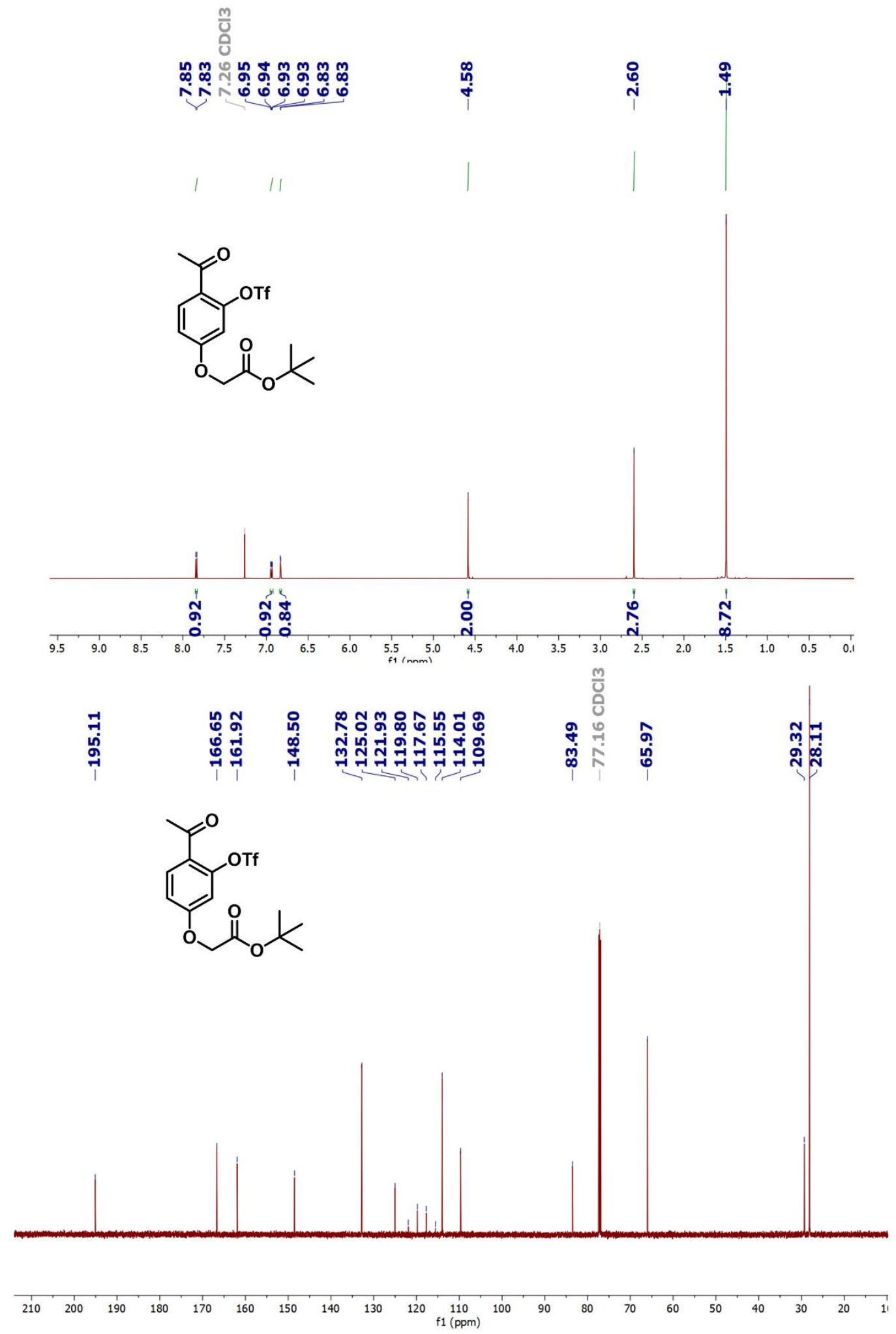




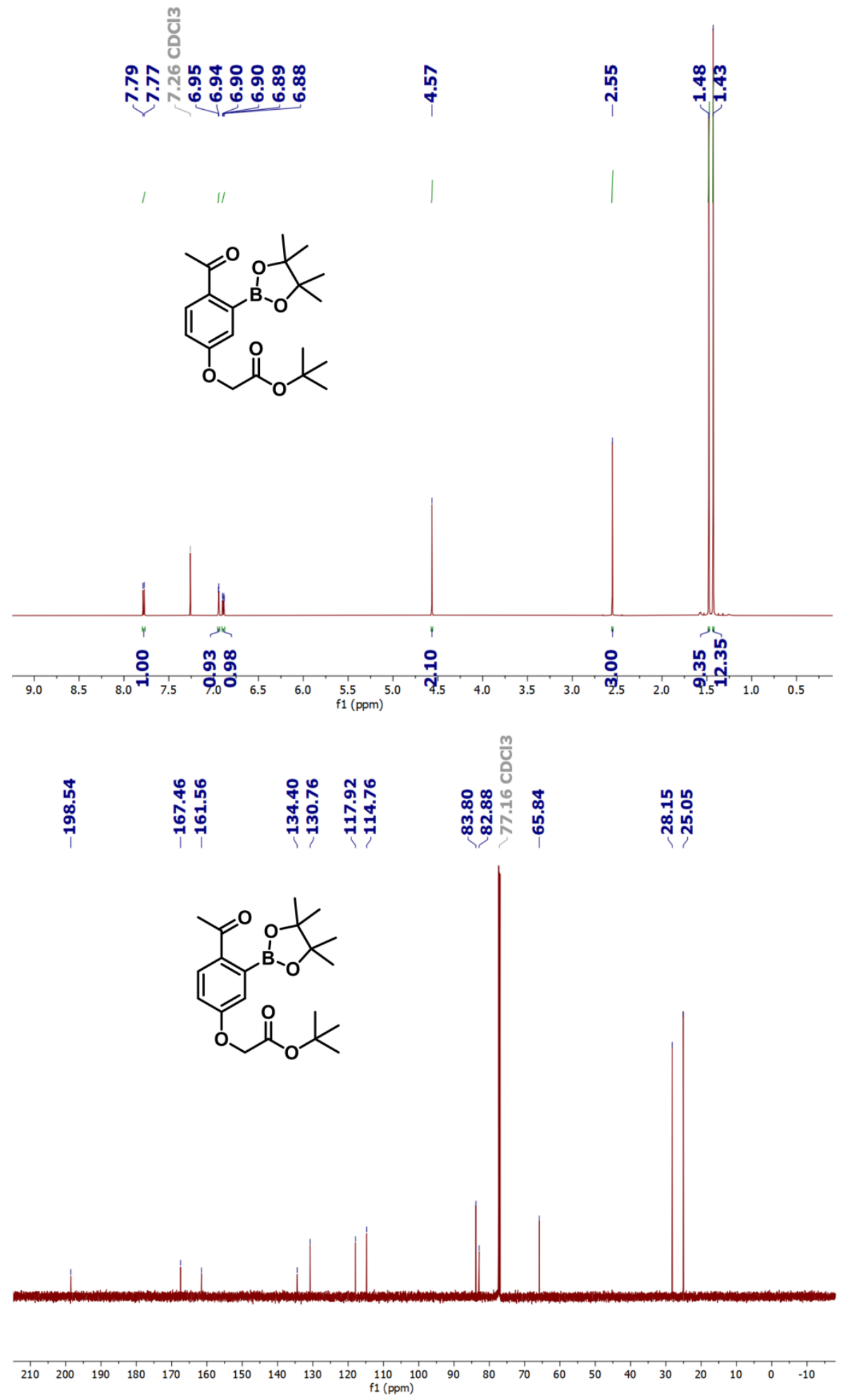



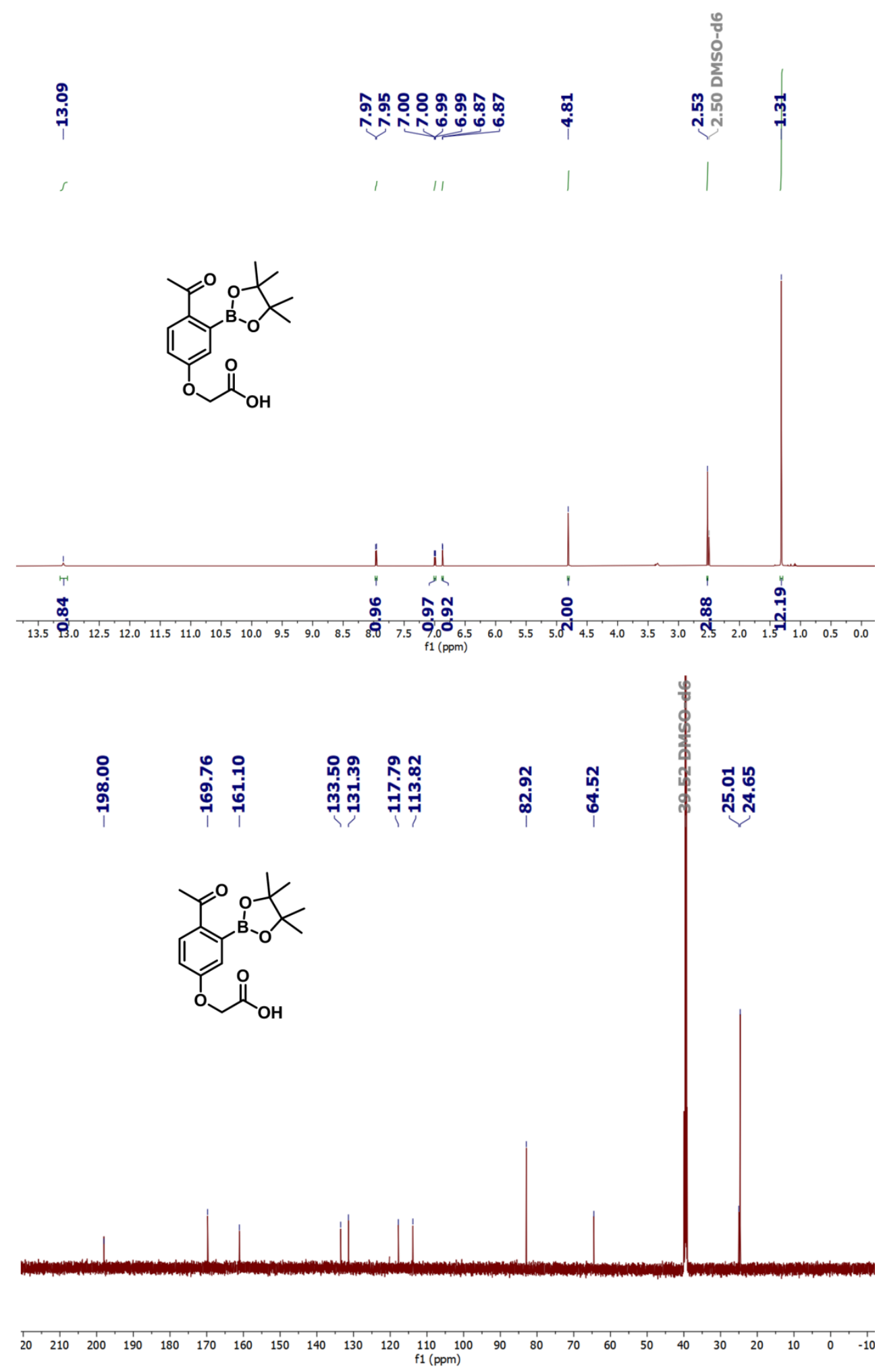

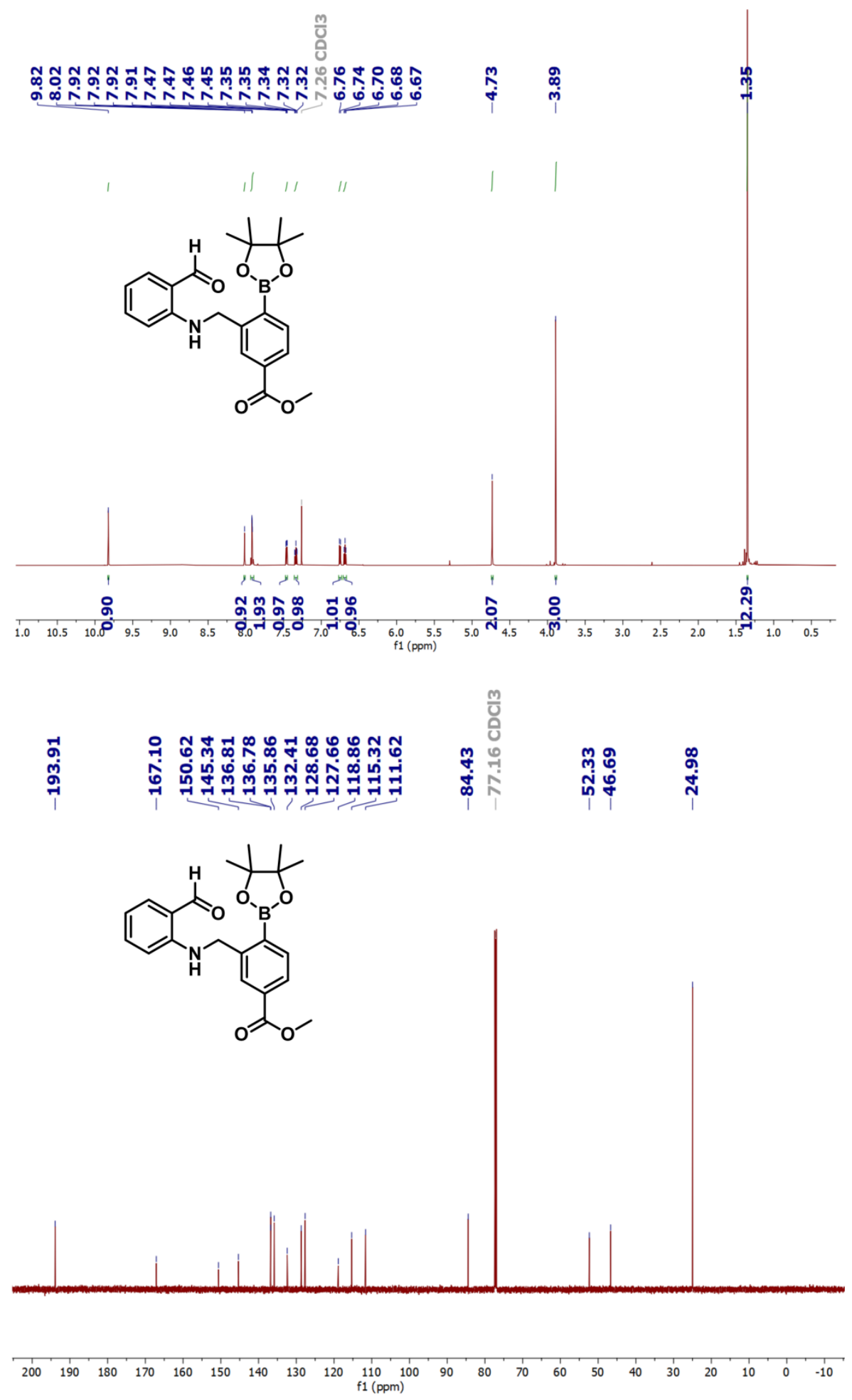

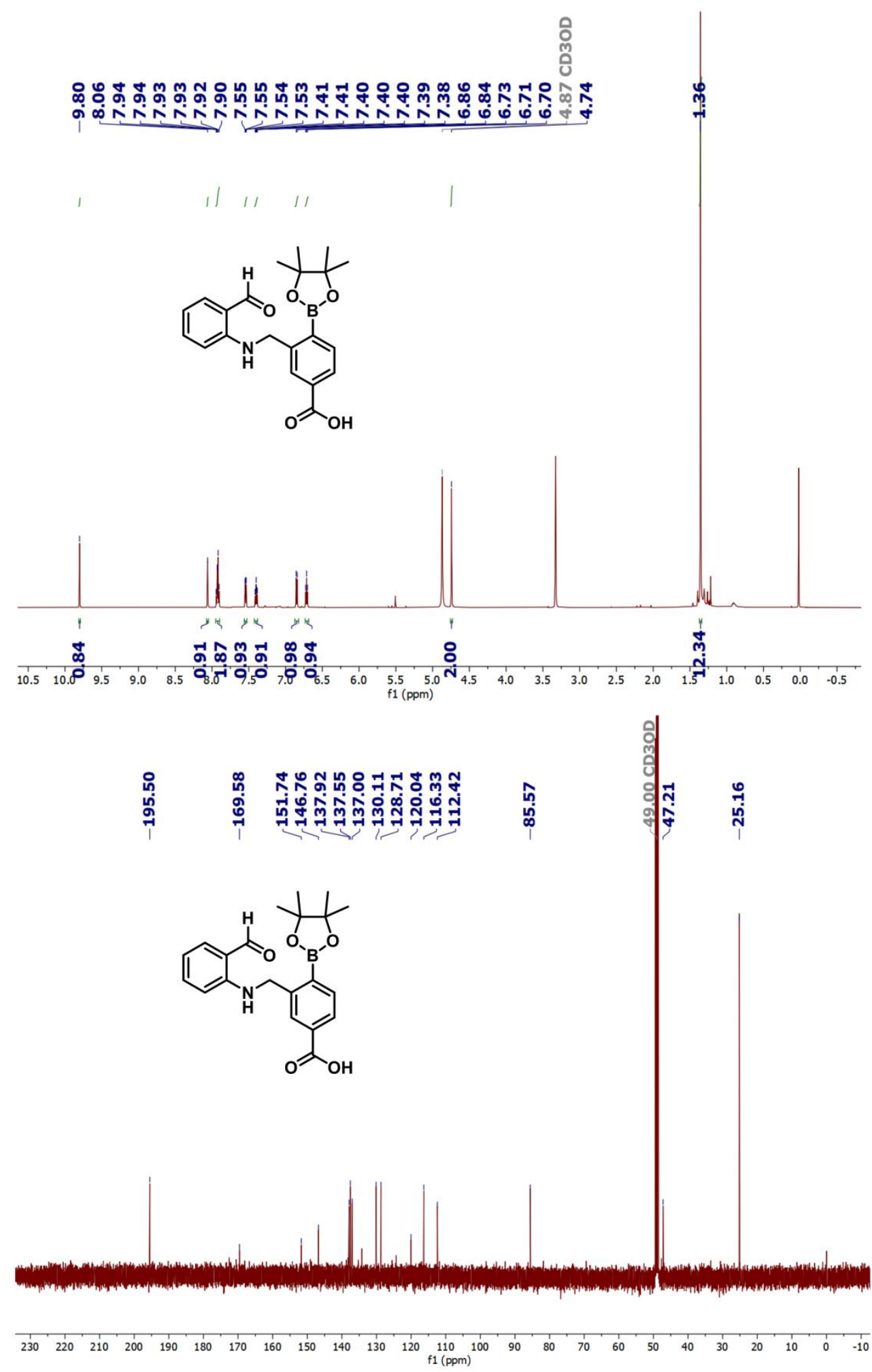

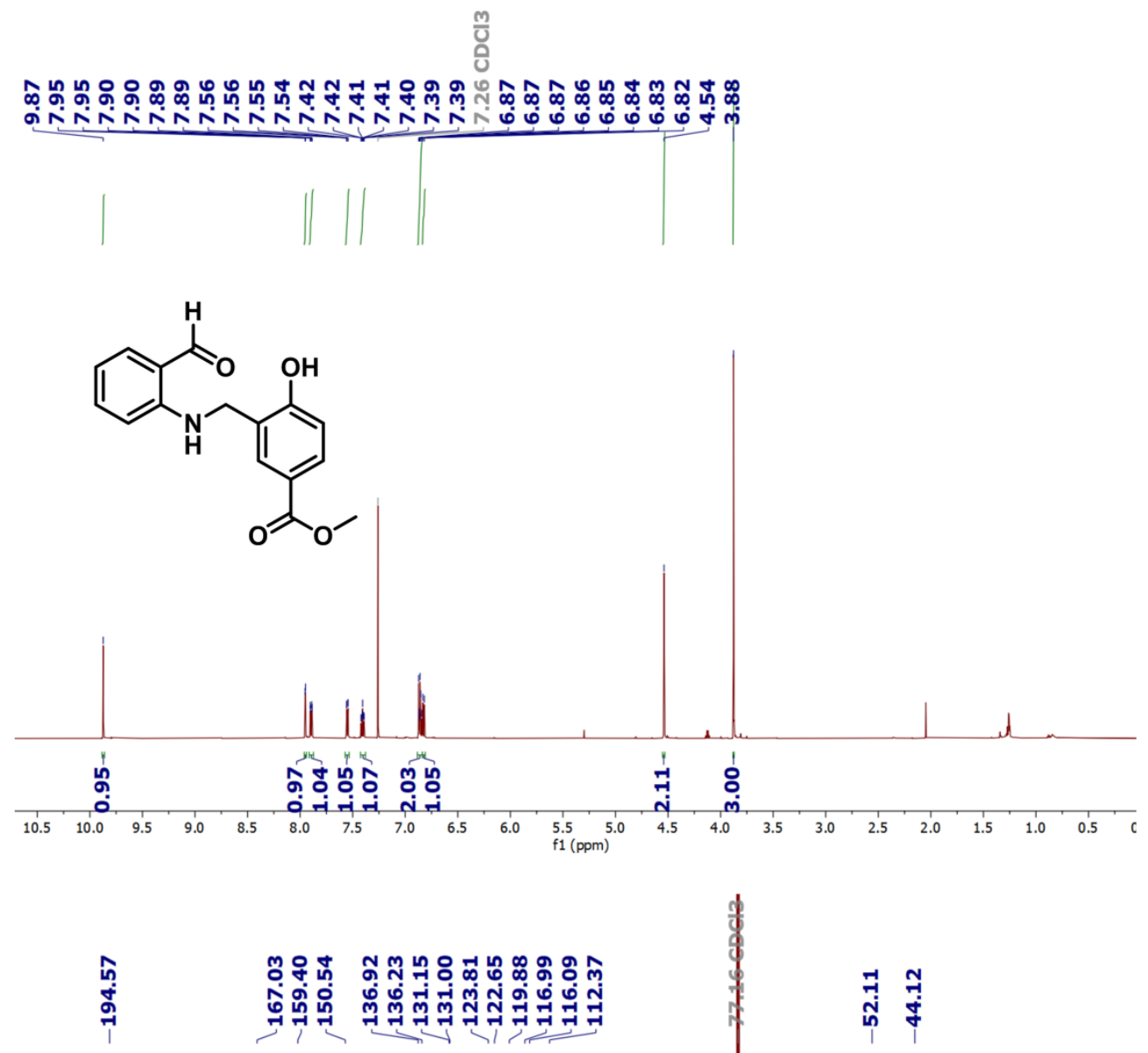

高辛<smiles>COC(=O)c1ccc(O)c(CNc2ccccc2C=O)c1</smiles>

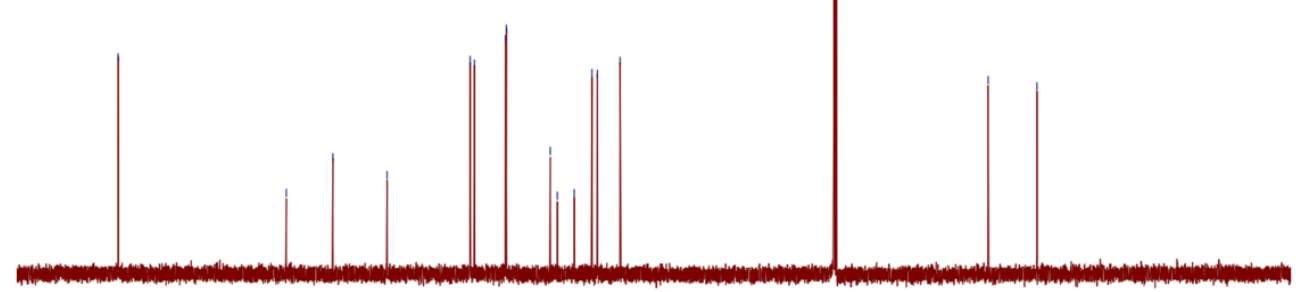

$\begin{array}{lllllllllllllllllllllllll}1 & 10 & 200 & 190 & 180 & 170 & 160 & 150 & 140 & 130 & 120 & \underset{\mathrm{f} 1(\mathrm{ppm})}{110} & 100 & 90 & 80 & 70 & 60 & 50 & 40 & 30 & 20 & 10\end{array}$ 

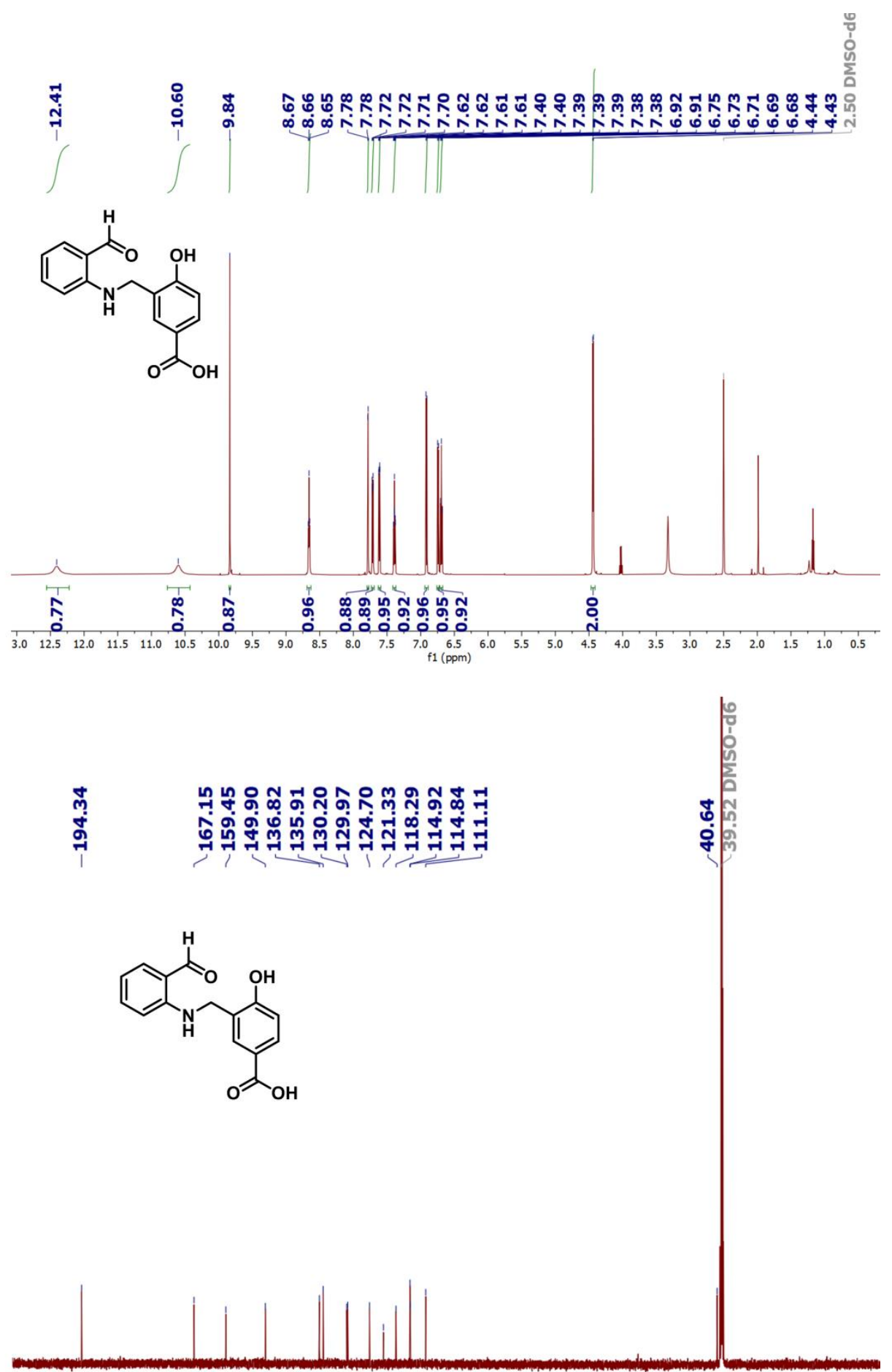

$\begin{array}{llllllllllllllllllllllllllllllll}10 & 200 & 190 & 180 & 170 & 160 & 150 & 140 & 130 & 120 & 110 & 100 & 90 & 80 & 70 & 60 & 50 & 40 & 30 & 20 & 10\end{array}$ 


\section{SI References:}

1. Li, K.; Wang, W.; Gao, J. Angew. Chem. Int. Ed.2020, 59, 14246.

2. Li, K.; Weidman, C.; Gao, J. Org. Lett. 2018, 20, 20.

3. Gaussian 16, Revision A.03, Frisch, M. J.; Trucks, G. W.; Schlegel, H. B.; Scuseria, G. E.; Robb, M. A.; Cheeseman, J. R.; Scalmani, G.; Barone, V.; Petersson, G. A.; Nakatsuji, H.; Li, X.; Caricato, M.; Marenich, A. V.; Bloino, J.; Janesko, B. G.; Gomperts, R.; Mennucci, B.; Hratchian, H. P.; Ortiz, J. V.; Izmaylov, A. F.; Sonnenberg, J. L.; Williams-Young, D.; Ding, F.; Lipparini, F.; Egidi, F.; Goings, J.; Peng, B.; Petrone, A.; Henderson, T.; Ranasinghe, D.; Zakrzewski, V. G.; Gao, J.; Rega, N.; Zheng, G.; Liang, W.; Hada, M.; Ehara, M.; Toyota, K.; Fukuda, R.; Hasegawa, J.; Ishida, M.; Nakajima, T. ; Honda, Y.; Kitao, O.; Nakai, H.; Vreven, T.; Throssell, K.; Montgomery, Jr. J. A.; Peralta, J. E.; Ogliaro, F.; Bearpark, M. J.; Heyd, J. J.; Brothers, E. N.; Kudin, K. N.; Staroverov, V. N.; Keith, T. A.; Kobayashi, R.; Normand, J.; Raghavachari, K.; Rendell, A. P.; Burant, J. C.; Iyengar, S. S.; Tomasi, J.; Cossi, M.; Millam, J. M.; Klene, M.; Adamo, C.; Cammi, R.; Ochterski, J. W.; Martin, R. L.; Morokuma, K.; Farkas, O.; Foresman, J. B.; Fox, D. J. Gaussian, Inc., Wallingford CT, 2016.

4. Wang, L.; Dai, C.; Burroughs, S. K.; Wang, S. L.; Wang, B. Chem. - Eur. J. 2013, 19, 7587

5. Bandyopadhyay, A.; Gao, J. Chem. - Eur. J. 2015, 21, 14748.

6. Trott, O.; Olson, A. J. J. Comput. Chem. 2010, 31, 7587.

7. Rentero Rebollo, I.; McCallin, S.; Bertoldo, D.; Entenza, J. M.; Moreillon, P.; Heinis, C. ACS Med. Chem. Lett. 2016, 7, 606-611. 